\title{
SIMBOLOGÍA MÍSTICA MUSULMANA EN SAN JUAN DE LA CRUZ Y EN SANTA TERESA DE JESÚS
}

\begin{abstract}
Los cristianos castellanos tardaron siglos en ir asimilando la estética, la mística, los procedimientos de la narfación y de la metáfora poética presente en la literatura de sus compatriotas moros; algún día se hablará de ello con la misma naturalidad con que decimos que Virgilio y Ovidio se hallan presentes en la literatura del siglo XVI.
\end{abstract}

Américo Castro

Después de la ingente obra del arabista Miguel Asín Palacios, a pocos sorprendería la asociación de la mística española del Siglo de Oro con la musulmana medieval. A nosotros también nos ha tocado corroborar en más de un estudio los estrechos paralelos existentes entre ambas escuelas. Pero el grado de islamización de esta literatura mística es mucho mayor de lo que hemos visto hasta la fecha ${ }^{1}$ y de lo que llegó a entrever el maestro Asín en sus ensayos comparatistas. Escritores como San Juan de la Cruz y Santa Teresa de Jesús - por mencionar sólo las figuras cimeras- nos deparan una sorpresa muy singular: comparten con sus correligionarios de Oriente muchos de sus símbolos y de su lenguaje técnico místico más importante. El

' Cf. nuestros estudios "Anonimía y posible filiación espiritual islámica del soneto *No me mueve, mi Dios, para quererte»", NRFH, 2 (1975), 243-266; "San Juan de la Cruz: una nueva concepción del lenguaje poético", $B H S$ (1978), 19-32: "Los lenguajes infinitos de San Juan de la Cruz e Ibn- ${ }^{-}$Arabi en Murcia", $\mathrm{CH}(6), 437-477$. "Chronique de la destruction d'un monde: la littérature aljamiadomorisque", Revue d'Histoire Maghrebine, 17-18 (1980), 44-73; en colaboración con María Teresa Narvaés, "Estudio sobre la espiritualidad popular del siglo XVI: la mora de Úbeda, el mancebo de Arébalo y San Juan de la Cruz", RDTP, 36 (1981), 14-51. "Huellas del Islam en San Juan de la Cruz: en torno a la «lama de amor viva» y la espiritualidad musulmana išraquí", Vuelta, 1988, núm. 45, 5-11 (este artículo incorpora muchas ideas vertidas en el apartado G., del presente trabajo); "El oráculo de Mahoma sobre la Andalucía musulmana de los últimos tiempos en un manuscrito aljamiado-morisco de la Biblioteca Na. cional de Paris" (en prensa en el HR, y, en versión árabe, en $R H M, 21 / 22(1981$ ); "Las problemáticas «profecías» de San Isidoro de Sevilla y de "Ali Ibnu Ŷebir Alferesiyo en torno al Islam español del siglo XVI: tres aljofores del manuscrito aljamiado 774 de la Biblioteca Nacional de Paris" NRFH, 29 (1980), 343-366. También está próximo a aparecer nuestro libro sobre el tema, San juan de la Cruz y el Islam (El Colegio de México). 
hecho es muy significativo porque implica, desde el punto de vista literario, que hay que buscar numerosos referentes del vocabulario sanjuanístico y teresiano entre los sufíes. Estamos ante el fenómeno de una literatura europea con numerosas claves literarias árabes, incluso, persas ${ }^{2}$. Veamos más de cerca.

Los poetas sufíes y sus comentadores, a pesar de manejar a menudo una lengua poética abierta de significados ilimitados y arbitrarios (pensemos en las glosas libérrimas a los versos místicos de Ibn ' Arabî y de Ibn al-Fárid, tan cercanas a las de San Juan) respetan sin embargo un número de equivalencias fijas. Se trata del lenguaje secreto - trobar clus avant la lettre- de cuya clave participaban, según críticos como Louis Massignon y Émile Dermenghem, exclusivamente los iniciados sufies:

Les mystiques, dit Lâhijî, commentateur du Goulchán-i Râz, Roseraie du Savoir, de Châbistarî. . . ont convenu d'exprimer par des métaphores leurs découvertes et leurs états spirituels; si ces images parfois étonnent, l'intention n'en est pas moins bonne. Les mystiques ont arrangé un langage que ne comprennent pas ceux qui n'ont pas leur expérience spirituelle, en sorte que lorsqu'ils expriment leurs états. . . comprend le sens de leurs termes, mais celui que n'y participe pas le sens lui en est inderdit. . . Certains initiés ont exprimé différentes degrés de la contempla tion mystique par ses symboles de vêtements, boucles de cheveux, joues, grains de beauté, vin, flambeaux, etc. . . qui aux yeux du vulgaire ne forment qu'une brillante apparence. . . . Ils ont signifié par la boucle la multiplicité des choses que cachent le visage de l'Aimé. . . le vin répresente l'amour, le désir ardent et l'ivresse spirituelle: le flambeau l'irradiation de lumière divide dans le coeur de celui qui suit la voie. . ." (Prólogo a L'Éloge du vin (Al Khamriya), poème mystique de 'Omar Ibn al Faridh, Paris, 1932, 62-63.)

\footnotetext{
2 Deseamos hacer unas advertencias en relación a estas fuentes persas. Algunas coincidencias entre la simbología literaria de la mística iraní y la de los reformadores del Carmelo nos parecen evidentes y las consignamos aquí: sin embargo, no creemos que se trate de una influencia directa, que sería, a todas luces, históricamente difícil. Más bien consideramos que los ejemplos de la simbología sufí persa que hemos documentado guardan a su vez relación cultural con el sufismoespañol y africano, que es el que probablemente ejerció una influencia cercana sobre el reformador y sobre la mística española en general. El misticismo persa musulmán implica una tradición literaria diferente en ciertos sentidos de la tradición literaria musulmana en lengua árabe: no nos podemos detener en estas variantes pero deseamos dejar consignado el hecho. De otra forma, también deseamos dejar en claro que hemos utilizado numerosos ejemplos de la tradición persa (aun cuando la tradición hispanoafricana y árabe en general es la que nos parece más elocuente), porque la documentación y los estudios críticos en este sentido son mucho más abundantes y accesibles. Con todo, observará el lector que hay casos en los que San Juan de la Cruz (o Santa Teresa) parecerían estar más cerca de ciertos símbolos característicos de la mística en la lengua persa. Difícil decir si se trata de que no hemos dado con el símbolo entre los sufíes del mundoárabe o si es que no existe entre ellos. Si este fuera el caso, sería entonces lícito afirmar que el reformador se encuentra de veras cerca de fuentes literarias persas-no árabes. Todo el fenómeno de la simbología mística sufí y sus repercusiones en Occidente necesita estudio adicional.
} 
Esta literatura en clave es antiquísima y constituye tradición literaria por lo menos desde el siglo x: 'Attār nos narra el diálogo de Ibn 'Ața' (muerto en 922):

«How is it with you sufies», certain theologians asked Ibn 'Ața', «that you have invented terms which sound strange to those who hear them, abandoning ordinary language?. . .»

«We do it because it is precious to us. . . and we desired that none but we Sufis should know of it. We did not wish to employ ordinary language, so we invented a special vocabulary ${ }^{3}$ ».

Los islamólogos insisten una y otra vez en ese "vocabulario especial": "the Ghazels or odes. . . are, to those who posses the key to their symbolic imagery, the fervent outpourings of hearts ecstasied. . ., intoxicated with spiritual love”, explica Margaret Smith", subrayando el sentido místico bajo la metaforización erótica. "But as time went on certain words began to have a recognized meaning amongst themselves". Florence Lederer ${ }^{5}$ tiene razón: el trobar clus termina por lexicalizarse y por devenir una convención literaria fácilmente reconocible. Pero reconocible - recordémoslo- dentro del Islam. De ahí que cuando sorprendemos esta misma imaginería simbólica secreta en las páginas piadosas e indudablemente cristianas de un San Juan de la Cruz, un Francisco de. Osuna, un Juan de los Angeles, una Santa Teresa de Jesús, no podemos sino plantearnos el fascinante enigma como auténtico problema histórico literario.

Veremos enseguida que las semejanzas no se limitan a estas equivalencias crípticas compartidas (cuyo origen dentro del Islam atribuye Massignon a fuentes coránicas $\left.{ }^{6}\right)$ sino que involucran también a una simbologia más amplia - y quizá más significativacomo la noche oscura del alma y las lámparas de fuero sanjuanísticas y los siete castillo concéntricos teresianos. Viene a la mente enseguida la simbologia escatológica musulmana que Asín Palacios propuso para la Divina Comedia ${ }^{7}$ : damos la razón al maestro y ponemos en perspectiva su libro (tan atacado cuando vio la luz en 1919): era el brillante preludio de todos los hallazgos que nos estaban deparados a los romanistas y arabistas empeñados en la tarea de comparar ambas literaturas y de seguir las huellas del estudioso. Vale la pena una aclaración breve antes de continuar. Atenderemos en conjunto en nuestro estudio las equivalencias técnicas - que a menudo rayan en alegoría- y los símbolos: su clara diferenciación resulta muy

3 FARID AL-DIN A TTAR, Muslim saints and mystics, London, 1966, pp; 237-238.

4 The Sufi path of love. An anthology of Sufism, London, 1954, p. 45.

${ }^{5}$ The secret rose garden of Sa'd Ud Din Mahmud Shabistari, Labore, 1969, p. 5.

${ }^{6} \mathrm{Cf}$. su libro Essai sur les origenes du lexique technique de la mystique musulmane, Paris, 1914-1922.

'La escatología musulmana en la "Divina comedia". Seguida de la historia y critica de una polémica, 3a. ed. Madrid, 1961. 
sutil y difícil, aun cuando estamos conscientes de los numerosos esfuerzos que han sido llevados a cabo (desde Aristóteles y Goethe hasta Henri Corbin y Seyyed Hossein Nasr) para deslindar teóricamente el símbolo de la alegoría. Pero aquí lo que nos interesa es ir al meollo fundamental e intentar demostrar que la literatura mística española, especialmente la literatura de San Juan de la Cruz y la de Santa Teresa, están nutridas por símiles, metáforas, equivalencias y símbolos - en una palabra, por una imaginería simbólica- tomada en buena medida del Islam. (En nuestro libro de próxima aparición, San Juan de la Cruz y el Islam, intentamos explorar a través de qué vías históricas).

Conviene advertir también que aunque destacaremos los estrechos paralelos de muchas imágenes y símbolos de San Juan y de Santa Teresa con los que usaron durante siglos (convirtiéndolos en tradición) los místicos del Islam, no por eso negamos la influencia fundamental de otras literaturas occidentales en ambos santos. Están presentes en el caso del reformador las huellas de la poesía castellana, de la culta italianizante, de la popular, de la cancioneril, de la lírica a lo divino, del Cantar de los cantares: hace tiempo lo tienen demostrado Dámaso Alonso, el P. Crisógono, María Rosa Lida, Colin Thompson. Intentaremos señalar, sin embargo, que aun cuando San Juan evidencia lecturas de estas fuentes e imita de cerca muchos versos, muchos giros e incluso el estilo de las mismas, el rico contenido semántico que han adquirido sus símbolos coincide estrechamente con el que esos mismos símbolos tienen entre los sufíes. Así, veremos cómo, aunque San Juan remede los versos de la Égloga II de Garcilaso ("hizo que de mi choza me saliese por el silencio de la noche oscura"), el santo eleva a símbolos el término y los pormenores con los que lo elabora parecen más cerca de Niffarí y de Yunayd que de las generalizaciones espirituales de Sebastián de Córdoba, a quien se sabe tuvo presente San Juan de la Cruz. Claro que San Juan está, estilísticamente, lejos de los árabes, pero buena parte de su simbología parecería pertenecer a la tradición literaria islámica. El caso de Santa Teresa es semejante: aunque apoye con pasajes bíblicos su equivalencia del castillo interior lleno de "aposentos" ("En la casa de mi Padre hay muchas moradas", San Juan 14,2 ), la concepción simbólica de siete castillos concéntricos que marcan el progreso místico a lo largo de siete moradas espirituales parece calcado de las frecuentes elaboraciones literarias que en este mismo sentido llevan a cabo, a lo largo de muchos siglos, los tratadistas musulmanes.

\section{SAN JUAN DE LA CRUZ}

Detengámonos en primer lugar en la obra del reformador, que, sorprendente "iniciado sufí", parecería conocer muchas de las cla- 
ves del trobar clus islámico y manejar el mismo lenguaje hermético de numerosos poetas místicos musulmanes. Damos por descontado, como cualquier lector elemental de Cari Jung, Evelyn Underhill o Mircea Eliade, que hay que tomar en cuenta la insistencia de todas las religiones en ciertos símbolos o imágenes fundamentales: la luz, el fuego, la oscuridad. Pero el caso de San Juan no es de estos: intentaremos demostrar que conoce con demasiada especificidad el contenido semántico de algunos de los símbolos islámicos más importantes como para tratarse de una coincidencia "casual" o esperable. Incluso en algunos casos en los que el símbolo estudiado pudiera ser patrimonio de la mística universal - como la subida al "monte" místico o la transmutación del alma en "pájaro"- la manera particular que tiene San Juan de pormenorizar dichas imágenes coincide estrechamente con la de los sufíes. Como era de esperar, hay variantes entre San Juan y los musulmanes, pero hemos podido documentar más de treinta de estas equivalencias fijas o símbolos compartidos. Detengámonos sólo en algunos de los más signifićativos, advirtiendo que hemos atendido en estudio aparte a los místicos europeos medievales que de una u otra manera se hacen también eco de esta simbología sufí que los precede por siglos.

\section{a) El vino o la embriaguez mística}

Aunque los sufíes no sean los primeros en utilizar el vino o la viña como arquetipo de sabiduría espiritual, (ya en el Gilgameš y en la Mišna encontramos la asociación $\left.{ }^{8}\right)$, en la literatura mística musulmana, tras numerosos siglos de uso, se lexicaliza la equivalencia del vino entendido invariablemente como éxtasis místico. San Juan de la Cruz lo usa siempre en este mismo sentido; parecería conocer la "clave"exegética" sufí al advertir en su "adobado vino" una "merced muy mayor que Dios hace a las almas aprovechadas, que las embriaga del Espíritu Santo con un vino de amor suave...que es el que Dios da a los ya perfectos..."' En otros versos en los que el recuerdo del Cantar de los cantares se nos hace patente, "En la interior bodega de mi Amado bebí”, estamos una vez más frente al éxtasis: “...el alma se transforma en Dios..." (VO, p. 700).

Sorprendemos la misma equivalencia vino=éxtasis entre los sufíes, que están muy conscientes de manejar un vocabulario técnico. Al declarar el verso de Ibn al Fárid, " Nous avons bu a la mémoire du Bien-Aimé un vin dont nous nous sommes enivrés avant la création de la vigne", dicen Būríní y Nábulusí:

Bồrîn - Sache que cette qacida est composée dans la langue technique des çoufis, dans le lexique desquels le Vin, avec ses noms et

8 MIRCEA ELIADE, Traité d'histoire des religions, Paris, 1950, p. 245.

9 SAN JUAN DE LA CRUZ, Vida y obras completas, BAC, Madrid, 1964, p. 697. En adelante, VO. 
ses attributs, signifie ce que Dieu a infusé en leur âme de connaissance, de désir et d'amour...Le vin, ici, c'est la Connaissance de Dieu et le désir. ardent d'aller vers Dieu (Al-Khamriya, p. 117).

Nâbolosî - Le Vin signifie la boisson de L'Amour Divin qui resulte de la contemplation des traces de ses beaux Noms. Car cet amour engendre l'ivresse et l'oubli complet de tout ce qui existe au monde (ibid., p. 119).

Los musulmanes se muestran más específicos y sofisticados en el manejo de este símbolo vinario que San Juan de la Cruz, que parecería tener un recuerdo vago aunque correcto de las equivalencias invariables. Así, para Ibn- Arabi la manifestación de Dios se da en cuatro niveles representados por la imagen de la bebida: el

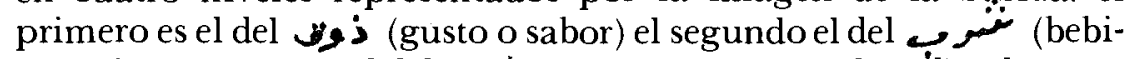
da o vino), el tercero el del $\mathbf{s}^{-}$(riego, extinción de la séd) y el cuarto (embriaguez). (Täjumān al Ashwäq. A collection of mysticall odes, London, 1911, p. 75. Abreviaremos TAA.) Si existe una equivalencia lexicalizada en el sufismo es esta del vino entendido como embriaguez extática. Los poetas persas Ŷaláloddin Rūmi, Śabistari y Hafiz̨ dedican poemas enteros a esta bebida, vedada por el Corán pero celebrada por ellos a un nuevo nivel secreto durante los siglos XII y XIII. Exclama Šabistarí en su "Wine of rapture":

Drink wine! for the bowl is the face of The Friend.

Drink wine! for the cup is his eye [. . .]

Drink this wine and, dying to self,

You will be freed from the spell of self. . .

What sweetness! What intoxication! What blissful ecstasy!

(The secret rose garden, Lahore, 1969, p. 43-35.)

El apasionado Rūmi está muy cerca del poeta carmelita: "el ardor del vino encendió mi pecho e inundó mis venas..." 10 exclama, y San Juan parecería seguirlo casi al pie de la letra: "así como la bebida se difunde y de[r]rama por todos los miembros y venas del cuerpo, así se difunde esta comunicación de Dios sustancialmente en toda el alma..." (VO, p. 700).

Por otra parte, en esta época del esplendor tardío de la poesía persa, el símbolo del vino es ya muy antiguo: lo reciben elaborado por Sa'di ${ }^{11}$, Simnānï, Algazel ${ }^{12}$. Una de las primeras veces que lo tenemos documentado es en el siglo IX, en que Bisţāmī y Yahyá ibn Mu'aḍ se intercambian apasionada correspondencia mística en clave, utilizando, como señala Annemarie Schimmel, precisamente esta terminología vinaria:

10 R. A. NICHOLSON, Poetas y misticos del Islam, traducción y estudio preliminar de Fernando Valera, México, 1945, p. 15.

1 Cf. MARGARET SMITH, op. cit., p. 113.

12 CF. FÉLIX M. PAREJA, La religiosidad musulmana, BAC, Madrid, 1954, p. 295. 
Sufi hagiography often mentions a letter sent to Bayezid [Bistämī, d. 874] by Yahyã ibn Mu'adh, who wrote: "I am intoxicated from having drunk so deeply of the cup of His love-'. Abū Yazid [Bāyesid] wrote to him in reply: "Someone else has drunk up the seas of Heaven and earth, but his thrist is not yet slaked: his tongue is hanging out and he is crying "Is there any more?" ( $A p u d$ Abū Nu'raym al'Isfahäni, Hilyat ul-auliyā, vol. 10, p. 40, Cairo, 1932'3).

A los teóricos del Islam no se les escapa, claro está el estudio de este símil, que comentan repetidas veces y que consideran de vital importancia para entedner esta literatura mística a clef. A menudo son los críticos quienes espigan matices específicos del símbolo que una vez más acercan a San Juan de la Cruz, asombrosamente, al sufismo. Laleh Bakhtiar subraya las emisiones o emanaciones que recibe el místico de Dios y que le alteran el alma: "Wine is a symbol for the ecstasy which causes the mystic to be beside himself in the presence of a vision or emanation of the Beloved...[subrayado nuestro]. Wine is the catalyst which causes a motion between the mystic's soul and the spiritual vision" 14 . De manera semejante, San Juan, al comentar sus enigmáticos versos "Al toque de centella,/ al adobado vino,/ emisiones de bálsamo divino" (VO, p. 697) alude al "exercicio que interiormente estas almas hacen con la voluntad, movidas por...dos mercedes y visitas interiores que el Amado les hace, a las cuales llama aquí toque de centella y adobado vino..." (VO, p. 697).

Aún más: San Juan de la Cruz usa la variante del mosto de granadas para el conocimiento y el delirio extático, advirtiendo cómo bajo la aparente multiplicidad de los granos de la fruta subyace la absoluta e indiscutible unidad de Dios, representada por la bebida embriagante:

Porque, así como de muchos granos de las granadas un solo mosto sale cuando se comen, así de todas estas maravillas... de Dios en el alma infundidas redunda en ella una fruición y deleite de amor, que es bebida del Espíritu Santo... bebida divina... (VO, p. 730).

Es precisamente esta fruta - la granada - la que marca la llegada del sufí a la cuarta etapa del camino o jardín místico y simboliza, según Bakhtiar, "the integration of multiplicity into unity, in the station of Union" (op. cit., p. 30). El anónimo Book of certainty, atribuido a Ibn-'Arabĩ o a Qăšāni, insiste en la fru ta emblemática de la esencia y unidad última de Dios: "The pomegranate, which is the fruit of the Paradise of the Essence... in the Station of Union...it is the direct consciousness of the Essence (ash-shuhûd adh-dhátî). . ${ }^{15}$

13 Apud ANNEMARIE SCHIMmel, Mystical dimensions of Islam, University of North Carolina, 1975, p. 51.

${ }_{14}$ Sufi expresions of the mystic quest, London, 1976, p. 113.

15 The book of certainty. Prol. de Abu Bakr Siraj Ed-Din, London, s.f., pp. 27-28 
La consecuencia de este vino o mosto espiritual es, como era de esperar, no sólo el conocimiento divino sino la embriaguez extática. Una vez más las tradiciones místicas de Oriente y Occidente se tocan. La "suave embriaguez" (VO, p. 697), cuya duración relativamente prolongada destaca San Juan, ocupa un lugar muy específico en el camino místico de 'Alá' al-Dawlah Simnáni: corresponde al número 87 de la novena etapa o grado extático (Bakhtiar, op. cit., p. 96). Al-Huŷwíri, en su Kašf al-Mahŷūb (el tratado sufí persa más antiguo con que contamos), hace un distingo: "there are two kinds of intoxication: 1) with the wine of affections (Mawaddat) and 2) with the cup of love (Mahabbat)"'16. San Juan celebrará la embriaguez con menos pormenores teóricos pero sin ambages en el "Cántico". Después de beber en la "interior bodega" del Amado: "cuando salía / por toda aquesta vega, / ya cosa no sabía / y el ganado perdí que antes seguía" (VO, p. 629). Cuán cerca del Divan de Shamsi Tabriz de Rūmí: "no tengo otro quehacer que la embriaguez y la algazara" (NICHOLSON. Poets ..., p. 126). Pero esta "borrachera" espiritual (si se nos permite el término) le es muy útil a San Juan, que adquiere, merced a ella, una lucidez muy especial porque implica un sensato olvido de lo creado: “... aquella bebida de altísima sabiduría de Dios que allí bebió le hace olvidar [al alma] todas las cosas del mundo, [que] en comparación de aquel sabor, es pura ignorancia" (VO, p. 701). En su citado Kašf al Mahŷūb Al-Hûywiri había expresado el mismo acerto casi al pie de la letra: la embriaguez es un "cerrar el amante los ojos a las cosas creadas, para ver al Creador en su Corazón” (apud Nicholson, Poetas. . ., p. 15).

Pero - ya lo habíamos anunciado- los sufíes son por lo general más sofisticados y detallados en la elaboración de estas equivalencias técnicas de su literatura mística. Así, tenemos la delicadeza suprema de distinguir con ellos - distingo que parece escapó a San Juan - entre los estados místicos de la embriaguez ( $s u k r)$ y la sobriedad (sahw). El citado Al-Huŷwíri -recordemos que vive hacia el siglo XI- revisa la larga polémica en torno a cual de los estados debería ser preferible. Al-Biṣtámi y sus seguidores prefieren la embriaguez, mientras que el autor del tratado, siguiendo a $\hat{Y}$ unayd (que a su vez sigue a su maestro) opta en un principio por la sobriedad. Los argumentos a través de los cuales se establece la distinción son sutilísimos y darían pie a una curiosa interrogante: ¿sería San Juan de la Cruz clasificable entre los embriagados como al-Biștámí? Con todo, y en una apoteósis mística inesperada y emocionante, al-Huŷwíri descubre que el grado extático supremo borra la aparente diversidad entre ambos estados (op. cit., p. 180).

In short, where true mystics tread, sobriety and intoxication are the effect of difference (ikhtilaf) and when the Sultan of Truth displays

${ }^{16}$ Kashf al-Mahjub of Al-Hujwìn. The oldest Persian treatise on Sufism, tr. by ReynoId A. Nicholson, London, 1976, p. 187. 
His beauty, both sobriety and intoxication appear to be intruders ( $t$ ufayli), because the boundaries of both are joined, and the end of the one is the beginning of the other... In union all separations are negated, as the poet says:

«When the morning-star of wine rises,

The drunken and the sober are as one».

Pero volvamos a la embriaguez extática que celebra San Juan de la Cruz con la mayor parte de los espirituales musulmanes. Un "borracho" habla sin coherencia: de la misma manera un embriagado místico emitirá palabras delirantes que traducen de alguna manera lo intraducibie de su experiencia espiritual. Una vez más, el santo parecería seguir las huellas de los sufíes que le preceden. Desde el mártir Hallay ${ }^{17}$ hasta la tardía secta sufí hispanoamericana de los šádilíes se insiste en que el místico auténtico no es dueño de su lenguaje:

Si la bebida persiste y dura hasta henchir las venas y articulaciones del amante con las luces misteriosas de Dios, viene la saturación que a veces llega hasta perder la conciencia de todo lo sensible e inteligible, y sin darse cuenta el sujeto de lo que le dicen ni de lo que dice él y esto es la embriaguez ${ }^{18}$.

El problema se agudiza cuando el delirio espiritual de estos embriagados se traduce en versos frecuentemente ininteligibles como los de un Ibn 'Arabi o un Ibn al-Farīd (Recordemos que los sufíes tuvieron en plena Edad Media una poesía que hoy consideraríamos "surrealista"). Los enigmáticos versos del Tarŷumān de Ibn'Arabí escapan a menudo - como los de San Juan- la intelección racional, y el místico de Murcia, meditando sobre las dificultades del lenguaje humano para traducir la Divinidad, admite que muchos pasajes le resultaban misteriosos aun al propio poeta (T.A.A., p. 7). Sus versos delirantes -esos "dislates" que tanto defendió San Juan en su propio caso (en el prólogo al "Cántico" nos dice que sus imágenes "antes parecen dislates que dichos puestos en razón", VO p. 626) - reciben en la mística sufí él nombre técnico de sătt y suelen constituir un fenómeno literario muy común. Al-Sarrāy explica en su Kitāb al Luma' (siglo X) el origen del término:

Just as a river in flood overflows its banks (shațaha 'l-ma' 'fi'l-nahr) so the sufi, when his ecstasy grows strong, cannot contain himself and finds relief in strange and obscure utterances, technically known as

17 La exclamación extática de al-Hallaŷ, "ana-1-haq" ("yo soy la Verdad [o Dios]") es célebre en el mundo islámico y le costó, si no su ejecución, sí severas reprobaciones teológicas. Cf. LOUIS MASSIGNON, Essai sur les origines..., p. 283, y La Passion de Hallāj, París, 1975.

18 ASÍN PALACIOS "Sādilies y alumbrados", AlAn, 12 (1947), p. 19. 
shatt... (Kitāb al-Luma -fi'l- Tasawuuf, ed. by Reynold Nicholson, Gibb Memorial Series, Leyden-London, 1914, p. 100).

El delirio es fenómeno universal, pero San Juan de la Cruz parecería estar de alguna manera familiarizado con la imagen asociada a la palabra árabe šatt, (= costa, ribera, playa, "that which is excessive or exceeds its proper bounds, excess", de acuerdo al $A$ rabic-English dictionary, ed. J.M. Cowan, New York, 1976, p. 471) que hace alusión a aquello que rebosa su cause normal:

...¿quién podrá escrebir lo que a las almas amorosas...Êl... hace entender? ... nadie lo puede, ni ellas mismas... lo pueden; porque es la causa por que figuras, comparaciones y semejanzas antes rebosan algo de lo que sienten y de la abundancia del espíritu vierten secretos y misterios... [que] parecen dislates. . . (VO, p. 626).

\section{b) La noche oscura del alma.}

El símbolo de la noche oscura del alma, el más famoso y el más complejo de San Juan de la Cruz, dejó perplejo al insigne sanjuanista francés Jean Baruzi, que no dio con las posibles fuentes que lo hubiesen podido inspirar. Opta por afirmar la supuesta originalidad del santo: "Aucun tradition n'avait beisoin d'être invoquée pour que nous puissons suivre le poete" (Saint Jean de la Croix et le problème de l'expérience mystique, Paris, 1924, p. 147) y por explicar que la noche - una noche metafórica ${ }^{19}$ - sería la manera en que se impondría a la intuición y al lenguaje de San Juan ese particular momento espiritual ${ }^{20}$ de su experiencia mística.

Las pistas que ofrece el propio San Juan al respecto son verdaderamente enigmáticas. En la Noche I, VIII, después de dividir dicho estado místico en noche sensitiva y noche espiritual, anuncia que

19 Decimos noche "metafórica" porque tenemos sobrados testimonios de que San Juan meditaba de noche en la soledad del campo. También rezaba de cara a la noche, que observaba desde la ventana de su celda. Comenta Baruzi: "le poète mystique adherait au silence des espaces nocturnes ou s'abimait en une perception limitée, perception soudain exaltée et devenue comme un signe de l'univers" (op. cit., p. 288).

${ }^{20}$ Evelyn Underhill (Mysticism, New York, 1961) describe teológicamente el estado espiritual de la noche oscura: "Psychologically,. . . the «Dark night of the soulw is due to the double fact of the exhaustion on an old state, and the grow th towards a new state of consciousness. It is a kgrowing pain» in the organic process of the soul's attainment of the Absolute. . . Parallel with the mental oscillations, upheavals and readjustments, through which an unstable psycho-physical type moves through new centers of consciousness, run the spiritual oscillations of a striving and ascending spiritual type. . . (p. 386) . . the travail of the Dark Nigh is all directed towards the essential mystic act of utter self-surrender; that fiat voluntas tua which marks the death of selfhood in interest of a new and deeper life" (p. 412).-Significativamente, la autora titula el capítulo de su libro que describe esta morada mística del deshacimiento purificador como "The dark night of the soul". Parece, sin duda, que toma prestado el término de San Juan, pues aunque muchos místicos atraviesan idéntico proceso espiritual, ninguno de los que menciona la estudiosa emplea el término técnico de la "noche oscura". 
hablará brevemente de la noche sensitiva: "porque della (como cosa más común) se hallan más cosas escritas, por pasar a tratar más de propósito de la Noche espiritual, por haber della muy poco lenguaje, así de plática como de escritura, y aun de experiencia muy poco" (VO, p. 552).

Difícil saber en qué fuentes concretas estaría pensando el santo, y si estaría recordando aquí a autores que aluden a la angustiosa morada espiritual con el nombre técnico específico de noche, o si simplemente describen la misma experiencia que San Juan "bautiza" como noche oscura. Cierto que la sutil diferenciación que establece el reformador (noche sensitiva, noche espiritual) y la alusión indirecta pero concreta a las fuentes tanto orales como escritas anteriores nos permitirían sospechar que el santo reconoce una tradición espiritual para su símbolo nocturno.

Esta tradición no resulta fácil de documentar. Se han encontrado, sin embargo, ciertos antecedentes parciales para esa enigmática noche sanjuanística. Algunos de ellos -más o menos cercanos al símbolo del santo- han sido ya señalados por la crítica.

Dámaso Alonso (La poesía de San Juan de la Cruz. Desde esta ladera) advierte los leves esbozos simbólicos de Sebastián de Córdoba y los estilísticos de Garcilaso (acaso a través de la refundición del mismo Córdoba) que San Juan de la Cruz parece recordar en sus versos. Colin Peter Thompson en su reciente libro St. John of the Cross. The poet and the mystic (Oxford 1977), explica que la noche oscura es asociable en última instancia a la divina caligo o tiniebla luminosa del Pseudo Dionisio Areopagita, aunque admite que el símbolo es mucho más elaborado en San Juan y que existen diferencias fundamentales entre ambos teóricos: "His dark night is an intímate personal experiencie compounded of many features, whereas Dionysius is concerned primarily with the metaphysical gulf which lies between the human and the divine" (p. 8).

Otros críticos coinciden en aceptar los distingos: "the mystics ... speak of the darkness of the night of purgation, and the dark night of the soul, but the Divine Darkness is in a different category from these"2l.

En efecto, pese a que San Juan cita directamente al Pseudo Dionisio, y pese a una innegable familiaridad general con sus doctrinas, la Divina Oscuridad y el "rayo de tiniebla" del antiguo maestro -esa oscuridad que es exceso de luz y que implica el conocimiento trascendental de Dios que no se obtiene por la razón discursiva - no parece resolver el problema de la aparente originalidad artística del símbolo nocturno del reformador carmelita.

21 Apud Dionysius the Areopagite, The mystical theology and the celestial hierarchies, London, 1949, p. 11. El comentario citado al "Darkness of Unknowing" aparece anónimo y sólo se especifica "Commentaries by the editors of the Shrine of Wisdom". 
Acaso nos sentimos un poco más cerca de San Juan al leer las Moralia de San Juan Gregorio, que no se limita, como el Pseudo Dionisio, a imágenes de oscuridad y luz, sino que interpreta las menciones esporádicas de la noche en Job y en los salmos (por ejemplo, los salmos 41:9, 15:7, Job 3:3, 3:23, entre otros) en términos de una, experiencia y proceso espiritual. Hay que advertirlo: el símbolo nocturno en los comentarios bíblicos de San Gregorio es variable y va cambiando de contenido semántico - pero otro tanto pasa con el de San Juan. El Padre de la Iglesia entiende la noche bíblica ya como luz excesiva que oscurece con su fuerza la luz intelectual natural (aquí estamos muy cerca del Pseudo Dionisio), ya como noche oscura de esta vida corporal, ya como las tribulationis noctem que, estamos plenamente de acuerdo con el padre Lawrence Sullivan, se acercan mucho a las sanjuanísticas: "The Nox of Psalm 41:9 is ... applied by Gregory (II 284) to a period in the spiritual life of all souls wherein they feel the withdrawal of God's protection, the loss of former consolation, spiritual weakness and emptiness and overwhelming sadness and darkness. This is a passive purification of the soul..."'22

Sin negar en manera alguna estas probables influencias cristianas, la compleja noche de San Juan -es forzoso admitirlo- rebasa los matices de sus supuestas fuentes. Recordemos - sin entrar en pormenores de los que tanto se han ocupado los críticos- que el poeta español infla semánticamente su noche simbólica, entendiéndola como "tránsito que hace el alma de Dios", como "privación del gusto en el apetito de las cosas", como "fe", como "aprietos y penas", entre muchos otros sentidos. A veces estamos cerca del Pseudo-Dionisio: la noche oscurece el espíritu pero es para darle luz, porque vacía el alma de lo creado para que goce de lo celestial (VO, p. 580). La pluralidad de los significados del símbolo ${ }^{23}$ en San Juan es tal que el santo llega al extremo de pretender que dos tratados distintos - la Subida del Monte Carmelo y la Noche oscura-expliquen simultáneamente el poema "En una noche oscura". Pero algunas de las modalidades de su complicada noche simbólica (entre otras, la apretura versus la anchura entendidas como estados espirituales alternos) no se encuentran entre los citados posibles antecedentes del santo. Una vez más, cuando acudimos a la literatura musulmana, muchos de los enigmas del símbolo más famoso del reformador carmelita van quedando resueltos.

Asín Palacios comenzó brillantemente las exploraciones en este sentido. Algo tímidamente y acosado, como se sabe, por la crítica (o

22 "Saint Gregory's Moralia and Saint John of the Cross", Ephemerides Carmeititicae, 28 (1977), pp. 62-63.

${ }_{23}$ Para un excelente estudio de la riqueza semántica de la oscuridad en San Juan, véase MARÍA JESÚS FERNANDEZ LEBORANS, Luz y oscuridad en la mistica española, Madrid, 1978. 
a menudo completamente ignorado por ella), el arabista asoció la noche oscura del alma sanjuanística a la de Ibn-'Abbad de Ronda y Abu-1-Hasan al-Sádita en su ensayo "Un precursor hispano-musulmán de San Juan de la Cruz" ( $A l A n 1,1933,7-79)$ y en su libro póstumo $\grave{S} a ̈ d i l i e s$ y alumbrados ${ }^{24}$.

Asín fue el primero en admitir la posibilidad de una fuente común que ayudase a explicar ciertas coincidencias entre la mística musulmana y la cristiana (entre ellas habría que incluir el símbolo de la noche oscura como etapa espiritual que nos ocupa). Aunque la influencia del monacato oriental cristiano sobre el Islam, defendida por Asín en su Islam cristianizado (ed. Plutarco, Madrid, 1931), es aún motivo de polémica, algunos sufíes podrían haberse nutrido -es plausible pensarlo- de autores como el Pseudo Dionisio Aeropagita. Con todo, y aun suponiendo que hayan recibido del primitivo cristianismo los rudimentos del símbolo de la noche, los místicos musulmanes medievales lo elaboraron con obsesión durante siglos, haciéndolo suyo y dotándolo de in trincados matices inmediatamente reconocibles como islámicos y no trazables - como admite Asína fuentes occidentales neoplatónicas. Justamente algunas de estas modalidades de la noche son las que vamos a sorprender en la literatura de San Juan, que parecería haber recibido el símbolo - acaso de antiguo origen cristiano- ya islamizado.

En primer lugar, Asín se dedicó a estudiar la noche oscura como imagen mística de sufíes tardíos como los šadilies del siglo XIII. El arabista no alcanzó a explorar la complejidad y la extensión del símbolo nocturno entre místicos musulmanes anteriores. Al explorar nosotros el símbolo, iremos encontrando en ellos distintas modalidades de la noche mística - que igualmente abundan, como hemos visto, en San Juan. En casi todas estas variantes encontraremos el presagio de la noche espiritual que el reformador carmelita fraguará como nadie en el siglo XVI.

Ya desde el siglo XII, Rūmí celebra su noche espiritual en apasionados versos: "Into my heart's night / Along a narrow way / I groped, and lo: The light, / and infinite land of day ${ }^{25}$.

Abū al-Māwáhib al Śádill también exclama extático en sus Máximas de la iluminación:

Oh night of love and happiness at home

Its joy drove our steeds to dancing gaits in merriment (p. 48).[. . .]

Obscurity is not disgraceful to the man of perfection.

For the 'night of Power' [Koran, s. 97]

is concealed while of all the nights 'tis the best ${ }^{26}$.

24 Este libro, que compilaron sus alumnos después de muerto el maestro, ocupa varios volúmenes de Al-Andalus: 9 (1944) - 16 (1951).

${ }^{25}$ Apud, ARTHUR J. ARBERRY, Sufism. An account of the mystics of Islam, London, 1968, p. 117.

${ }^{26}$ Apud EDWARD JABRA JURGl, Illumination in Islamic mysticism, Princeton University Press, 1938, p. 59. 
La noche no siempre es tan celebrable para los musulmanes: a menudo la ven, como San Juan, en términos angustiosos. Así, el anónimo autor del citado Libro de la certeza advierte el "complete abscence of the Lore of Certainty [that] corresponds to the darkest of nights" (p. 67) y Lāhỉjì (muy cerca de San Gregorio) intuye la noche de nuestra condición humana: "Assumer la condition humaine, c'est se trouver dans cette nuit, ou plutôt, c'est être cette nuit. . . .27

Uno de los téoricos más complejos del sufismo, Naŷm ad-dín al-Kubrā, del siglo XIII, de cuyo tratado Fawä'ih al-Ỹămāl wa-

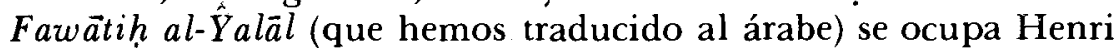
Corbin en su libro L'homme de lumière dans le soufisme irannian (Paris, 1961), establece la distinción -y también en ello nos recuerda las sutilezas de San Juan- entre la "... Nuit lumineuse de la surconscience et la Nuit ténébreuse de l'inconscience. La Ténèbre divine ...la «Nuit des symboles» au sein de laquelle l'ăme progresse, ce n'est nullement la Ténèbre ..." (pp. 20-21). Sa'adi, de otra parte, declara que él puede -exactamente igual que San Juan- "appreciate the prolongation of the long, dark night" (Smith, The Sufi ..., p. 113) como etapa espiritual ardua pero necesaria y Śabastarỉ, en su famoso Rosal secreto, más cerca aun del santo carmelita, exclama en un verso célebre para todo sufí: "Nuit lummineuse, midi obscur!" (Corbin, L'homme. . . p. 117). Recordemos la noche de San Juan, "más clara que la luz del mediodía"28. Este verso de Sabastarỉ recibe numerosos comentarios, entre ellos el de Lāhỉjî, digno de la complejidad y la hondura del de San Juan de la Cruz:

'Comment énoncerai-je ce qu'il en est d'un cas si subtil? Nuit lumineuse, Midi obscur! (v. 125)", s'écrie encore le poète de la Roserai du Mystère. Son commentateur le sait: pour qui a expérimenté cet état mystique, une allusion suffit. . E Et Láhijî s'enchante de cette Nuit ilumineuse roshan) qui est Midi obscur, mystique aurore bóreale ... C'est bien une ( hab-e roshan) qui est Midi obscur, mystique aurore bóreale. . C'est bien une Nuit, puisque lumiere noire et abscondité de la pure Essence, nuit de puisqu'elle est en même temps la théophanie de l'absconditum, en la multitude infinie de ses formes théophaniques... Midi, milieu du Jour... c'est-à-dire plein jour de lumières suprasensibles... que les mystiques perçoivent par leur organe de lumière, leur l'œil intérieur. . .; et pourtant Midi obscur, puisque la multitude de ces formes théophaniques son aussi les 70,000 voiles de lumière et de ténebres qui occulant la

27 Apud HENRI CORBIN, Trilogie Ismalienne, Teheran-Paris, 1961, p. 38.

${ }^{28}$ El juego metafórico con una noche mística "luminosa" parece bastante común en la mística musulmana. Leamos la variante de Rumi: "And the beloved is the moon beyond the horizons which trakes its rest place (qonug) in the lover's heart for just one night, since the night regards itself as white and luminous during full moon, the lover, dark night himself, becomes enlightned by the moon-like beloved" (apud A. SCHIMMEL, The triumphal sun. A study of the works of falaloddin Rumi, London, The Hague, 1978, p. 343). 
pure Essence... Nuit de la pure Essence, sans couleur ni détermination, inaccessible au sujet connarssant. . . Et portant Nuit lumineuse, puisqu'elle est celle que fait être ce sujet en se faisant voir par lui, cellequi le fait voir en le faisant être midi obscur des formes théophaniques, certes, puisque livrées a elle-mêmes elles seraint ténèbres et non-être,et que dans leur manifestation même, "elles se montrent cachées!" (Corbin, Trilogie..., p. 177).

Esta "noche divina de lo incognosible" de Suhrawardi (Corbin, op. cit.), y de Avicena (ibid., p. 20) marca distintas moradas del camino hacia Dios. Para Semnānī, se trata del sexto grado, el del "aswād nūrānï" (luz negra); para el crítico Corbin, "noche luminosa" constituye "l'étape initiatique la plus périlleuse" (ibid., p. 151). Tanto para Lāhỉjì como para Naŷm Rāzi la noche implica la culminación extática -el grado séptimo y final que es el de la luz negra y que resulta - como para San Juan- "envahissante, anéantissante" (ibid., p. 161). (Estamos cerca del "rayo de tiniebla" del Pseudo-Dionisio: advirtamos cómo los sufies parecen ir adaptando las ideas del antiguo místico en términos de un proceso espiritual, cosa que los acerca más a San Juan). Niffarí, ya desde principios del siglo $\mathrm{X}$ (seis siglos antes que San Juan) y con una voluntad teórica muy definida que indefectiblemente nos recuerda a la del santo reformador, entiende también su noche oscura personal como un hito en el camino que conduce al éxtasis último:

Il me posa dans la station de la Nuit, puis II me dit: quand te survient la Nuit tiens-toi devant Moi et saisis en ta main la Nescience (gahl): par elle tu détourneras de Moi la science des cieux et de la terre, et en la détournant, tu verras Ma descente (Mawäqif) ${ }^{29}$

También el persa Rūmi ve concretamente cómo el místico debe abrazar y aceptar esta noche que conduce precisamente a la intuición de la unidad esencial de Dios:

Take the Leyla 'Night' (leyl) on your breast, o Majnun ${ }^{30}$.

The night is the secret chamber of towhid [ unidad de Dios], and the day idolatry (sherk) and multiplicity... ${ }^{31}$

En el siglo XIII $\operatorname{lbn}^{\mathrm{c}}$ Arabī repetirá el aserto teórico de tantos correligionarios sufíes que de una manera u otra recogerá San Juan

\footnotetext{
${ }^{29}$ Apud PAUL NWYIA, Ibm 'Ata' Allăh et la naissance de la confrérie šadilite, Beyrouth, 1971, p. 105.

${ }^{30}$ Rūmi emplea un juego de palabras con el nombre árabe "Leila", que en esa lengua significa también "noche". Leila y Maýnum eran una pareja famosa de amantes, tal el Romeo y Julieta occidentales.

31 Apud SCHIMmEL, The Triumphal ..., p. 346.
} 
en el Renacimiento: la noche marca una etapa o morada de la vía mística cercana ya a la unión. Se trata de la estación de la proximidad (T.A.A., p. 146) muy cercana ya a los "levantes del aurora" o posesión final de Dios. Para ambos, como para tantos otros sufíes, la noche estática se encuentra iluminada por relámpagos o manifestaciones abruptas de la esencia divina. A menudo las coincidencias entre San Juan y los místicos de Oriente resultan muy estrechas: Ibn al-Fárid llega a poetizar en su Ta'iyyat al Kobrä(The greater poem rhyming in $T$ ) del siglo XIII una modalidad que conocerá el santo en el siglo XVI: la noche de los sentidos: "And thou, illumined, knowest by His light/Thou find'st His actions in the sense's night" (apud Schimmel, Mystical. . ., p. 277).

Tan importante es para los sufíes esta noche simbólica que el anónimo autor del citado Book of Certainty asocia el nombre de la amada más famosa del Islam, la Beatriz o la Julieta musulmana, Leila, con dicha noche espiritual ${ }^{32}$. Es que Leila significa noche en árabe: "... in Arabic stories and lyrics the beloved is so often named Laila (Night) for the night is above all a symbol of the Passive Perfection of Beauty... the lover's desire may ... be taken to represent ... his aspiration to the Truth Itself ..." (pp. 63-64).

Ante esta insistencia, no es de extrañar que aun escuchemos entre los moriscos españoles del siglo XVI, culturalmente agonizantes, los últimos ecos de esta noche simbólica tan especial, todavía entendida como etapa de sufrimiento espiritual o moral en estos versos de un zéjel a Mahoma, cuya versión en aljamiado recogen Julián Ribera y Asín Palacios:

\author{
Quien quiera buena ventura \\ alcançar grada de altura \\ porponga en la noche escura \\ l'aççala sobre Mahommad ${ }^{38}$.
}

\footnotetext{
32 Merece más estudio aún el motivo poético frecuente en la poesía laica árabe del amado que se desliza subrepticiamente en la noche para encontrarse con su amada. Algunos críticos creen que este motivo se utilizó "a lo divino" en la literatura mística. De ser cierto, estaríamos sin duda muy cerca del poema "En una noche oscura..." de San Juan de la Cruz, de idéntica trama amorosa que debe ser entendida divinalmente. James $T$. Monroe alude a la tradición poética árabe laica: "In one section of his Risāla, the poet [Abu 'Amir ibn Suhaid, 922-1035, que escribe bajo el Califato de Córdoba] attends a gathering of literary critics who were discussing poetry. The discussion resolves around the topic of how a theme (ma'na) can gradually be refined by successive poets. A theme is proposed: That of the lover who creeps softy through the dark to visit the beloved, doing so as quietly as possible in order to avoid being heard by her guardians. A good example by Imru'al Qais is cited, followed by a bad one by "Umar ibn Abi Rabi' a" " "Hispano-Arabic poetry during the caliphate of Córdoba", en Arabic Poetry. Theory and development, Weisbaden, 1973, p. 142). Para su salida nocturna subrepticia, San Juan había utilizado la "secreta escala". Uno de los símbolos favoritos de Rümī, "again in tune with Sana'i's imagery, is that of the ladder or stair case (nardabān) which will eventually lead the lover to the roof, where the beloved is waiting". (SCHIMMEL, The Triumphal ..., p. 289).

33 Mañuscritos árabes y aljamiados de la Biblioteca de la Junta, Centro de Estudios
} 
Curiosamente, hasta los versos que riman con la noche oscura parecerían coincidir con los de San Juan: "buena ventura" en el zéjel anónimo, "dichosa ventura” en las célebres liras del Santo.

Hemos visto como los sufies, en sus profusas elaboraciones del símbolo nocturno, parecerían preludiar y hacernos esperable la irrupción de la elusiva noche sanjuanística en la España del Siglo de Oro. Pero las coincidencias - ya lo anunciamos- resultan aún más estrechas. Ya Asín exploró - y es justo repetir sus palabras- que el carmelita utiliza, como parte de su explicación de la noche, una terminología muy precisa que parecería repetir muy de cerca la que siglos antes trabajaron los šădiles: el bast o anchura de espíritu, que es un sentimiento de consuelo y dulzura espiritual, se asocia entre ellos al día y se contrasta con el $q a b d$ o apretura, estado de angustia o desolación que se asocia a su vez a la noche oscura del alma ${ }^{34}$, en la que Dios sume al místico para desasirlo de todo lo que no es Él. San Juan, al igual que los šadilies, nos depara la sorpresa de preferir el estado de la noche o qabd y Asín descubre que el santo repite al detalle los matices que ambos términos técnicos poseen en árabe:

El término técnico qabd, que como hemos visto es el quicio sobre el que gira toda la teoría šádili, deriva de la raíz árabe qabada, que tiene los siguientes sentidos, directos o metafóricos: "coger", "sujetar", "apretar", "tomar", "contraerse", "sentir disgusto", "estar triste", "experimentar angustia", "apretarse el corazón”. El término, pues, funciona en los textos árabes con la misma rica variedad de ideas, hermanas de las que San Juan de la Cruz expresa con las voces castellanas siguientes, que a cada línea se repiten en la Noche oscura del alma: "aprieto", "apretura", "prisión", "oprimir", "poner en estrecho", "tortura", "angustia", "pena".

Su opuesto, el término bast, que en árabe significa directamente "extender", "ensanchar", "dilatar", "abrir la mano", y, en sentido metafórico, "alegrarse", "estar cómodo", "regocijarse", "sentir bienestar"; "estar contento", es también sinónimo de la voz castellana "anchura", que con los dos valores, directo y traslaticio, usa igualmente, aunque con menos frecuencia que "aprieto", San Juan de la Cruz" ("Sádilies. . .", AlAn, 11, 1946, p. 8).

Los paralelos estrechos se suceden: la noche de San Juan encierra la triple ecuación del qabd sufí: aprieto del alma por su purgación pasiva y activa; desolación espiritual; noche oscura en cuyas tinieblas Dios se revela al alma más frecuentemente que en el día de la iluminación o anchura.

Históricos, Madrid, 1912, manuscritos XII, IX.-James T. Monroe cita el mismo zéjel recogido también por Saavedra y Moragas, y lo asocia a la noche oscura de San Juan; véase Islam and the Arabs in Spanish scholarship, Leiden, 1970, p. 111.

34 Cf. Asin Palacios, “Un precursor...” pp. 262 y 272. 
Asín limita su estudio al caso de los šádilies ${ }^{35}$, pero es importante señalar que la presencia de los términos qabd y bast en el Islam es muchísimo más antigua. Massingnon advierte que se trata de léxico coránico, pues lo encontramos en la azora II, 246 del Libro revelado. Ponderemos en el significado literario de poder documentar el vocabulario técnico de San Juan en el Corán de los musulmanes; que el Corán sea uno de los "contextos" literarios de San Juan. Pero no nos quedamos ahí: distintas escuelas sufíes repiten y comentan los citados términos técnicos. Entre otros, Algazel (cf. Asín, La espiritualidad. . ., III, p. 165), Ibn-'Arabi (Tarŷumän. . ., p. 56) Qušayri (cf. Nwyia, Ibn 'Ata' Allāh . . ., 261-262), Al-Sarrāŷy, Ibn al Farìd (cf. Pareja, La religiosidad. . ., p. 320). Para el teórico Simnāni, el qabd y el bast corresponden a las etapas 85 y 86 del IX escalafón del camino místico (Bakhtiar, pp. 96-97), mientras que para el más poético Kubrā (Fawa'ih al-Ŷamäl wa - Fäwațih al-Ŷalăl, Weisbaden, 1957 p. 43)

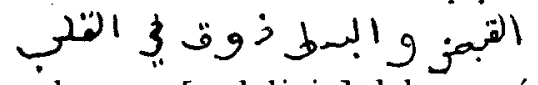

"la apretura y la anchura son el gusto [o delicia] del corazón".

Annemarie Schimmel advierte cómo la predilección por el estado del qabḍ le viene a Ibn- 'Abbād de Ronda de "Junayd as well as by the school of Abū Maydan" (Mystical ..., p. 253). Ŷunayd defendía su extraña preferencia: "when He [God] preses me through fear $\mathrm{He}$ makes me disappear from myself, but when He expands me through hope He gives me back to myself" (Schimmel, ibid., p. 129). Otros místicos como el citado tratadista Al-Huŷwirí alude en el siglo XI a los debates de los šeijs o maestros sobre cuál de los estados - qabd o bast- era preferible ${ }^{36}$. Con todo, la preferencia por la apretura acercaría a San Juan a Ŷunayd, a Ibn 'Abbád', a Abū-l-Hasan al Sāảili, incluso más que al propio San Gregorio, que en sus Moralia asocia brevemente el día a la paz espiritual y la noche al sufrimiento $\mathrm{o}^{37}$.

35 Asín se refiere principalmente al qabd y al bast cuando comenta: "Eliminando... los vocablos técnicos y las imágenes metafóricas comunes a ambas escuelas por depender de la misma tradición cristiana y neoplatónica, todavía queda un residuo no despreciable de símbolos y de voces comunes que carecen de precedente en aquella tradición y que son patrimonio privativo de la escuela šâdili y de la mística de San Juan de la Cruz" (ibid., pp. 270-271).

36 Qabd (contraction) and bast (expansion) are two involuntary states which cannot be induced by any human act or banished by any human exertion. God hath said: "God contracts and expands" (Kor. II, 246). Qabd denotes contraction of the heart in the state of being veiled, and bast denotes the expansion of the heart in the state of revelation (Kashf). Both states proceed from God without effort on the part of Man. . . Some Shaykhs hold that qabd is superior in degree to bast for two reasons; (1) it is mentioned before bast in The Koran, (2) $q a b d$ involves dissolution and oppression, whereas bast involves nutrition and favour ... Others, again, hold that bast is superior to qabd. The fact, they say, that qabd is mentioned before bast in the Koran shows the superiority of bast, for the Arabs are accostumed to mention in the first place that which is inferior in merit ... Moreover, they argue that in bast there is joy and in qabd grief. . ." (Kashf al-Mahjub, pp. 374-375).

37 Job's enjoyment of spiritual peace and prosperity is likened to Day, but in his sufferings he entered into a Night: "Unde bene per prophetam dicitur: «In die mandavit Dominus 
Acaso la curiosa división que lleva a cabo San Juan de su noche mística en tres momento claramente delimitados (prima noche, media noche, final de la noche o antelucano; VO, p. 395), obedezca también a referentes culturales musulmanes o árabes. En árabe, el término " significa "primer tercio de la noche" (Cowan, ArabicEnglish dictionary ..., p. 46) y algunos místicos musulmanes como Du'n-Num aluden a la noche tripartita. San Juan coincide estrechamente con Ibn-"Arabí: para ambos, "the last third of the Night" (Taryumān ..., p. 95) implica ya la cercanía de la aurora del conocimiento divino ${ }^{38}$.

La insistencia tan tenaz en esta noche secreta e iniciática entre los sufíes podría acaso tener origen -o al menos guardar relacióncon las elaboraciones místicas de la leyenda del viaje nocturno o išra que Mahoma, "de nocte et nullo vidente" en palabras de Raimundo Martín (Asín, Escatología ..., p. 583) realiza al séptimo cielo. El origen de la leyenda es, una vez más, coránico. Aunque la azora XVII, 1 hace referencia concreta a la experiencia del Profeta, los sufíes, como señalan Massignon (Passion ..., p. 312) y Asín, "se apoderan de la leyenda y tienen la audacia de arrogarse el papel de protagonistas, en sustitución de Mahoma" (Escatologia, p. 76). Comentan y transforman en experiencia espiritual privada los versículos coránicos, como vemos hace aquí el anónimo autor del Book of certainty:

Verily we sent it down in the Night of Power. / And how canst thou tell the Night of Power? The Night of Power is better than a thoussand months. /The Angels and the Spirit descend therein from the source of all decrees by the leave of their Lord. Peace it is until the break of down. (Qoran, XCVII).

...the Chapter of Power, which if interpreted with reference to the microcosm may be taken as a hymn of the perfect soul's marriage with the Spirit, the "Night of Power" being the soul of the Saint, into which alone descends the Spirit... (p. 62) ${ }^{39}$.

misericordiam suam, et in nocte declaravit» (Ps. 41:9). Misericordia enim Domini in die mandatur, quia in tranquilo tempore cognoscendo percipitur; in nocte vero declaratur, quia donum, quod in tranquillitate sumitur, in tribulationibus manifestatur" ( $A$ pud SULLIVAN, St. Gregory's «Moralia». . , p. 62).

${ }^{38}$ San Juan esgrime argumentos bíblicos para respaldar sus "tres partes" de la noche, pero parecería que interpreta la noche tripartica de Tobías desde postulados fundamentalmente musulmanes. La noche es un camino espiritual purificador que culmina en la posesión de Dios: "En el libro del Santo Tobías (6, 18-22) se figuraron estas tres maneras de noches por las tres noches que el ángel mandó a Tobías $e l$ mozo que pasasen antes que se juntase en uno con la esposa. En la primera le mandó que quemase el corazón del pez en el fuego, que significa el corazón aficionado . . . a las cosas del mundo . . . En la segunda noche le dijo que sería admitido en la compañía de los santos patriarcas, que son los padres de la fe . . En la tercera noche le dijo el ángel que conseguiría la bendición, que es Dios . . " (VO, p. 368).

39 ". . The Night-Journey, the ascension to heaven to which the Koran (Sura 17/1) alludes ... has been interpreted from at least the days of Bayazid Bestami as the prototype of 
Comentarios alegórico-místicos del $m i^{c} r a \vec{y} \hat{y}$ o ascención celeste de Mahoma como éste que acabamos de ver - recordemos el Libro del nocturno viaje hacia la majestad del más generoso de Ibn-' Arabi (Escatología ..., p. 77) y acaso el Tratado del viaje nocturno ${ }^{40}$ de Suhrawardi- formen una tradición consistente que fortalece una vez más, dentro del Islam, el símbolo nocturno. Hay detalles específicos que traen a la memoria una vez más la noche de San Juan. La descripción que Bakhtiar (op. cit., p. 84) hace de esta "Night of "Might" "a lo divino" de los sufíes podría casi ser un comentario del poema en el que, en una noche oscura, el alma de San Juan sale "sin ser notada": "The ascent of the Sufi occurs in what is known as the Night of Power, when the Heavens open ...his soul is as the darkness of night (recordemos a San Juan: "a oscuras ...sin otra luz ni guía") [his] Heart, now full, totally reflects the sun" (el corazón de San Juan irradia de la misma manera en medio de las tinieblas: "sin otra luz ni guía / sino la que en el corazón ardía. / Aquesta me guiaba / más cierto que la luz del mediodía ...") which brings tranquillity, until the break of dawn ..." También el santo, en su noche "amable más que alborada" termina por sumirse en una paz sin límites: "Quédeme y olvidéme ... cesó todo y dejéme ..." (VO, p. 363).

El tratado en que se describe el $m i^{\epsilon} r a \bar{y} \hat{y}$ del Profeta (y que se tradujo al latín y a las lenguas neorrománticas bajo el Sabio ${ }^{41}$ ) se titula, como se sabe, el Libro de la escala de Mahoma (Liber Scale Machometi, ms. Lat. 6.064, fols. $105 \mathrm{v} / 126 \mathrm{v}$, Paris). ¿Habrá ecos lejanos de esta escala mahomética en a escala del poema de San Juan, aunque se trate de un leit-motiv espiritual bastante común que el santo asocia a San Bernardo y a Santo Tomás? (cf. supra, nota 32). Es que la escala, dentro del contexto específico de una subida espiritual secreta y nocturna al cielo, no puede no recordar el $m i^{*} r \vec{a} \hat{y}$ musulmán. El santo roza las líneas generales de dicha leyenda al comentar su escala nocturna como la "secreta contemplación" en la que sube el alma a escalar, conocer y poseer los bienes y tesoros del cielo" (VO, p. 601). Del cielo: curiosamente, San Juan aquí parece más cerca de la leyenda de la ascención celestial de Mahoma que de los sufíes que transforman místicamente el mito.

Esta noche mística de San Juan y de los sufíes deviene, por último, la deseada aurora de los principios — todavía tenues - del conocimiento divino. María Teresa Narváez advierte en su ensayo, "San Juan de la Cruz y Algazel: paralelos" (Boletín de la Academia

the mystics flight into the inmediate Divine prescence and thus as a symbol for the highest spiritual experience..." (SCHIMMEL, The Triumphal. ., p. 285).

to Cf. SEYYED HOSSEIN NASR, Three Muslim sages: Avicena, Suhrawardi, lbn-`Arabi, Harvard University Press, 1964, p. 59.

${ }^{41}$ Cf. JOSÉ MUNOZ SENDINO, La escala de Mahoma. Traducción del árabe al castellano, latín y francés, ordenada por Alfonso X el Sabio, Madrid, 1949; y DOROTHEE METLITZKI, The matter of Araby in Medieval England, Yale University Press, 1977. 
Puertorriqueña de la Lengua, 2, 1977, pp. 75-92) cómo a Asín Palacios parece habérsele escapado el cercano paralelo que en este sentido guardan el filósofo musulmán y el reformador castellano. Comenta Asín el uso de la imagen por Algazel:

A veces, adaptando el tecnicismo convencional de los sufíes, llama [Algazel] en su Imla "levantes" o "auroras" (Tawali) a los resplandores nacientes de la intuición divina, cuyo brillo, aunque exiguo, basta para apagar en el horizonte de la conciencia las cosas que no son Dios, al modo del Sol que con su todavía pálido esplendor apaga los de las estrellas $^{42}$.

Pero veamos cuán cercano está San Juan de esta versión algaceliana al comentar su verso "la noche sosegada" / en par de los levantes del aurora". Realmente se hace pálido el recuerdo de la esquemática aurora "a lo divino" de Sebastián de Córdoba:

...así como los levantes de la mañana despiden la escuridad de la noche y descubren la luz del día, así este espíritu sosegado y quieto en Dios es levantado de las tinieblas del conocimiento natural a la luz matutinal del conocimiento sobrenatural de Dios no claro sino (como dicho es) escuro...Como noche en par de los levantes, ni del todo es noche ni del todo es día, sino, como dicen, entre dos luces... (VO, p. 670. Apud NARVÁEZ, pp. 87-88).

Hasta el sosiego de este estado matutino en el que tanto insiste San Juan fue preludiado por los sufies: "The break of dawn is the moment when the peace is annihilated in the Light of the Absolute, leaving only the Absolute Peace of Unity" (Bakhtiar, p. 84). De la misma manera, San Juan, después de la noche oscura de su alma que culmina en la luz más clara que el mediodía, se hace uno con Dios y deja su cuidado "entre las azucenas olvidado".

c) Iluminación interior. La llama de amor viva y las lámparas de fuego

Desvièmos nuestra atención hacia otro de los símbolos más importantes de San Juan de la Cruz: la iluminación interior. Principalmente en su poema la "Llama de amor viva", que no ha recibido demasiada atención de los estudiosos, el santo celebra la luz y las llamas en las que arde su alma extática y las misteriosas lámparas de fuego que la alumbran en el instante de su transformación en Dios. La luz como símbolo es, sin duda, universal: lo vemos elaborado en las Jerarquías celestes del Pseudo Dionisio y Mircea Eliade nos 
llama la atención sobre las distintas culturas que lo hacen suyos: el judaismo, el helenismo, el gnosticismo, el sincretismo, el cristianismo en general ${ }^{43}$. Pero en San Juan de la Cruz muchos de los pormenores del símbolo parecen, una vez más, sufíes. El misticismo islámico se obsede con el símil de la iluminación desde muy temprano -acaso, como proponen Edward Jabra Jurji ${ }^{44}$ y Annemarie Schimmel, porque funden frecuentemente las ideas de Plotino y Platón con las de Zoroastro y otros sabios persas antiguos. Suhrawardí, llamado al-maqtūl (el asesinado "o ejecutado") muerto en 1191, está considerado como el "šeij al-išrāq", maestro de la filosofía de la iluminación, gracias a su abundante literatura sobre el tema: escribe cerca de cincuenta libros en árabe y en persa, influidos por Avicena, por el helenismo y por importantes elementos iraníes y orientales antiguos, entre los que cabe recordar su Hikmät al-išrāq (La filosofía de la iluminación) y su Hayākil an-nūr(Los altares de la luz). Sus seguidores insisten de tal manera en esta luz interior que ganan el sobrenombre de išraquies, literalmente "iluminados" o "alumbrados" como aquella secta perseguida del XVI español"4. Para San Juan fue muy peligrosa la acusación de alumbrado que pesó sobre él ante la Inquisición, pero entre sus correligionarios musulmanes no era tan grave o incomún el apelativo. Ibn-"Arabi lo usa como autoridad: "One of the illuminati told me ..." (T.A.A., p. 84). El mismo respeto encontramos en Algazel, quien, al referirse a un maestro sufí en su Ihyä' (IV, 176-179) dice con unción: "Un hombre, de aquellos a quienes la luz increada ilumina con sus resplandores ..." (apud Asín, La espiritualidad ..., II, p. 363). El motivo de la iluminación es común a toda la mística islámica, que lo denomina con variados nombres técnicos como el zawa'id (exceso de luz o de iluminación espiritual en el corazón $)^{46}$ y los críticos no dejan de advertir su importancia: Domingo de Santa Teresa vio entre los šádilíes "un exagerado apoyo en la iluminación interior, en la lumbre divina" 47 , mientras que Annemarie Schimmel, más entusiasta, alude al "highly developed light metaphysics" del Nicho de las luces de Algazel (Mystical ..., p. 96). En efecto: los sufíes desarrollan el símbolo con minucia: en su $I h y=\bar{a}^{\prime}$, el citado filósofo persa asigna a la iluminación

49 Cf. También el estudio de la simbología de la iluminación en los espirituales occidentales (Dante, Jacopone di Todi, San Agustín, Santa Catarina de Génova, etc.) en el capítulo "The illimination of the self" del citado Mysticism de Evelyn Underhill.

${ }_{44}$ Illuminations im Islamic mysticism, Princeton Ứniversity Press, 1938, p. 12.

45 Curiosamente, el paralelo escapa a Asín y a Antonio Márquez (Los alumbrados. Orígenes y filosofía: 1525-1559, Madrid, 1972). El vocablo "alumbrado" merece más estudio. Ahora se aplica en castellano el apelativo de "alumbrado" a un borracho (¿tenue recuerdo de esta secta a menudo delirante de "embriagados" espirituales?). También no deja de ser peculiar el uso de vocablos de sentido orientalizante para la "borrachera": una "curda", una "turca".

${ }_{46}$ AL HUYWIRI, op., cit., p. 384.

${ }^{47}$ Juan de Valdés (1498-1541). Su pensamiento religioso y las corrientes espirituales de su tiempo, Universitatis Gregoriana Romae, 1957, p. 17. 
el tercer grado del tawhì o unidad con Dios: "au troiseme [degré] on ... contemple [l'Unité de Dieu] par ilumination intérieure" 48 , mientras que para el más tardío Abū-l-Hasan al-Śdili se trata del cuarto grado de la ascención espiritual, en que "Dios alumbra al alma con la luz del intelecto original en medio de las luces de la certeza mística" 49 .

Pero el siempre minucioso tratadista del siglo XI Huŷwiri presenta una distinción sutil: "There is a difference between one who is burned by His Majesty in the fire of love and one who is illuminated by $\mathrm{His}$ beauty in the light of contemplation" (Kashf al-Mahjub, apud Schimmel, Mystical ..., p. 6). Si bien San Juan nos hablará en muchos pasajes de la luz interior con la que el "Padre de las lumbres" (Iac. 1, 17; VO, p. 836) ilumina su espíritu, insiste mucho más en la "llama de amor viva" que es su alma en el momento de su transformación en Dios. Es la misma metáfora que los apasionadísimos sufíes utilizan a lo largo de la Edad Media, siglos antes de que el emblema del Corazón de Jesús y María incendiado en llamas de amor deviniese popular, cosa que ocurre, de acuerdo al Dictionnaire de Spiritualité (t. 2, París, 1953), hacia los siglos XVII o XVIII.

El poema sanjuanístico de la "Llama" y su minucioso comentario, aparentemente muy original dentro del contexto del Renacimiento europeo, va pareciéndonos menos extraño dentro de los contextos literarios islámicos. Avicena, por ejemplo, sabe reconocer el quinto hal o estado extático gracias a las brillantes llamas del conocimiento directo de Alá (cf. Pareja, op. cit., p. 378) que inflaman "de su alma en el más profundo centro" que el filósofo denomina técnicamente como "qalb" 50 . Invariablemente pormenorizado en su tratamiento de los símbolos, Kubrá establece la diferencia entre el fuego del demonio y el fuego espiritual del $\underline{d i k r}(=$ oración repetida, memoria de Dios, recogimiento), que el místico deberá reconocer "comme un flamboient ardent et pur, animé d'un mouvement ascendant et rapide" (Corbin, L'homme ..., pp. 113-114; Kubrá, apdo. 8). "Ațtár celebra en un poema ese mismo fuego: "What is wajd? (ecstasy) .../ to become fire without the presence of the sun" (Schimmel, Mystical ..., pp. 48-49).

Pero las coincidencias aumentan. Para casi cada elemento simbólico que emplea San Juan en su luminoso poema comentado, en el

48 Ihyä' 'ulum al-Din, Livre XXXV, París, 1959, p. 381.

49 Mafajir, 97, 199 apud ASí, Sadilies ..., pp. 259-260; cf. tamién el caso de Ahmad al-Kharrāz, apud M. SMITH, The Sufi '..., pp. 121-122.

${ }^{50} \mathrm{La}$ concepción exacta del qalb o centro más profundo del alma es muy compleja entre los sufies. Algunos lo conciben como un órgano a la vez físico y espiritual y capaz de conocer a Dios. También suelen subdividir el órgano de la comunicación espiritual en distintos grados o centros profundos donde se experimentan diferentes momentos del proceso místico. Nūrī de Bagdad, por ejemplo, subdivide el "corazón" (o este proceso extático) en cuatro grados, que culminan con el lubb o "corazón más profundo". Comenta A. Schimmel que, sin embargo, "Sufis often add the element of sirr, the innermost heart in which the divine revelation is experimented" (Mystical ..., p. 192 cf. también R. A. NICHOLSON, op. cit., p. 97. 
que el P. Crisógono advierte el recuerdo del verso " $O$ Oh fuego de amor vivo!" de Boscán y Dámaso Alonso el recuerdo del "Boscán a lo divino" de Córdoba, encontraremos paralelos místicos sufíes acaso más significativos. No son difíciles de documentar. El más notable, sin duda, el de las lámparas de fuego, que Baruzi, quizás por parecerle excesivamente enigmático, lo declara "una image, en elle même assez pauvre" (op. cit.,p. 360). Con escasas excepciones, la lámpara alumbra místicamente al centro del alma del sufi aprovechado en la vía mística. Bayazíd celebra "tener dentro de sí la lámpara de la eternidad"' (Nicholson, Poets ..., p. 79), Rūzbehān de Shiraz (1209) advierte las "nombreuses lampes qui répandent une vive lumière" (Corbin, L'homme ..., p. 79) en su alma; Algazel insiste en lo esplendente de la "luz de la lámpara que arde en su corazón" (Asín, La espiritualidad ..., p. 371), mientras que el tantas veces citado Ibn- 'Arabi enseña que el corazón es la habitación de Dios y el gnóstico debe "alumbrarlo con las lámparas de las virtudes celestiales y divinas hasta que su luz penetre en todos sus rincones" (Asín, El Islam ..., p. 423). Las lámparas místicas se convierten habrá que usar el término- en un lugar común del sufismo que reaparece una y otra vez entre espirituales musulmanes de diversos países y siglos. Esta tradición parecería tener origen en los abundantes comentarios a la famosa azora de la lámpara (24:35) del Corán:

God is the Light of the Heavens and the earth:

The likenes of This Light is as a niche wherein a lamp (the lamp in a glass, the glass as it were a glittering star) kindled from a Blessed Tree

an olive that is neither of the East nor of the West whose oil wellnigh shine, even if no fire touched it; Light upon Light:

(God guides to His Light whom He will) $)^{51}$.

Ya al-Muhsáibí, nacido en Basora en 781, en su tratado Fasl fi-'l-mahabba (Tratado sobre el amor) interpreta "místicamente" la azora: Dios enciende una lámpara inextinguible que termina por iluminar las más secretas "cavernas" u orificios del corazón del gnóstico: "When God kindles that the lamp in the heart of His servant, it burns fiercely in the crevices of his heart he is lightned by it..." (Arberry, Sufism ..., p. 50). Otro que aplica la azora a sus experiencias espirituales privadas es Algazel, que en su Nicho de las luces subraya - como San Juan - la condición autónoma de esta lámpara interior: "self-luminous and with no external source..." (Bakhtiar, p. 20).

51 Versión inglesa de A. J. Arberry, The Koran interpreted, Oxford, 1964, pp. 356-357. 
Estas lámparas simbólicas, tan largamente trabajadas por los musulmames ${ }^{52}$, parecerían de alguna manera asomar en la imagen que San Juan desgaja del Cantar de los cantares: "quia fortis est un mors dilectio, dura sicut infernus aemulatio, lampades ejus, lampades ignis atque flammarum", 7:6. El santo desvirtúa el sentido bíblico literal y al reinterpretar estas "lámparas" lo hace en términos muy parecidos a los que acabamos de ver. Pero aun nos aguarda otra sorpresa: San Juan coincide al detalle con varios de estos místicos musulmanes en cuanto a su interpretación exacta de estas lámparas espirituales: para Algazel, significan los "archetypes or Divine Names and Qualities" (Niche for Lights, apud Bakhtiar, p. 20) y para los śádilies, a través de los Sarh al-Hikam (I, 69) de Ibn-'Abbád de Ronda, "las luces de los atributos [divinos] ... (Asín, "Šādilies" ..., AlAn, 13, 1948, p. 264). Es justamente así como San Juan entiende sus propias lámparas de fuego. Aún más: tan lejano cronológica y geográficaente del reformador carmelita, Nuri de Bagdad en su Maqāmät al qulüb (Moradas de los corazones) del siglo IX, tratado que hemos traducido del árabe en su totalidad, aclara cuales son estos atributos divinos que se entienden por lámparas de fuego:

Il [Dieu] a suspendu (dans la maison du coeur) une lampe d'entre lęs lampes de Sa bonté... l'allumant a l'huile de la justice et faisant briller sa lumière par la lumiere de sa pieté... (NWYIA, Exégèse..., p. 327).

Los atributos de la lámpara (o la luz que producen) son prácticamente los mismos en las glosas de San Juan a su poema: bondad, justicia, misericordia:

...el resplandor que le da esta lámpara de Dios [el alma] en cuanto es bondad... y, ni más ni menos, le es lámpara de justicia, y de fortaleza, y de misericordia, y de todos los demás atributos que al alma juntamente se le representan en Dios (VO., p. 872).

Las palabras de Laleh Bakhtiar parecerían poder aplicarse a San Juan cuando analiza el símbolo sufí de la lámpara de fuego, que considera "related to the intelligence (that is, the thinking function

\footnotetext{
${ }^{52}$ Hay un poema de Rümī (traducido por W. Hastie) que entrevera los símbolos de la lámpara y de la noche a los que hemos aludido: eran sin duda recurrentes en la literatura mística islámica: "All Unbelief is midnight, but Faith the Night-Lamp's glow; / Then see that no thief cometh to steal Thy Lamp when low, / Our hope is for the Sunlight, from which the Lamp did shine; / The Light from it kindles, still feeds its flame below; / But when the sun hath risen, both Night and Lamp go out; / And Unbelief and Faith then, the higher Vision know, / O Night! Why art thou dreaming? O Lamp! Why flickerest so? / The swift Sunhorses panting, from East their fire-foam throw, / Tis Night still in the shadow; the village Lamp burns dim; / But in Dawn's Splendour towering, the Peaks Heaven's Glory show". (M. Smith, op. cit., pp. 93-94).
} 
of the will) for it is this faculty which recognizes the Archetypes or Divine Names or Qualities" (op. cit., p. 20). San Juan, sin embargo, y como de costumbre, respalda su explicación del símbolo con el aludido pasaje bíblico "Conoce aquí bien el alma la verdad de aquel dicho de el Esposo en los Cantares, cuando dijo que las lámparas del amor eran lámparas de fuego y de llamas $(8,6)$ " (VO, p. 873). El santo está forzando la palabra literal de la Biblia al aplicarle, como en tantas otras ocasiones, una interpretación concorde con la simbología mística musulmana. ¿Estaría, en cierto sentido y acaso sin advertirlo, este cristiano sincero pero gran mestizo cultural que es San Juan, “islamizando" las Escrituras?

Islamiza, por lo menos, su propia literatura, porque los paralelos minuciosos continúan. Las lámparas o luces espirituales marcan también para el sufí la morada del conocimiento: la certeza mística (la cuarta en el Tabaqāt Śa'rani (11, 10-11) de Abū-1-Hasan al-Śdidi y el grado del anwār al-yaqin o luces de la certidumbre para Abū Hafs al-Suhrawardi (nota 1234).

También para San Juan el conocimiento de los atributos de Dios da paso al conocimiento total de Él: “... oh de deleites! donde de tal manera se conoce (VO, p. 880). El proceso termina, en palabras de San Juan, con "la transformación del alma en Dios [que] totalmente es indecible" (VO, p. 876). Para el citado Suhrawardi, también estamos ante la transformación final del alma en Dios, el haqq al-yaqin "el punto en el que el amante queda ... inmerso en la luz de la contemplación ... y queda transformado, y este es el Supremo grado de la unión" (Pareja, op. cit., p. 396). Para que este prodigio ocurra, el fuego y las lámparas han purificado el alma de lo que no es Dios: San Juan, a la luz de sus propios comentarios, estaría plenamente de acuerdo con la vívida interpretación que da Kubrá a la acción purificadora del fuego del $\underline{d} i k \mathrm{r}$ : (recogimiento) surge en el alma proclamando: "anā, wa lā geíri!" ( 5 s , bl ) "yo, y nada más" y une su llama a las del corazón incendiado del

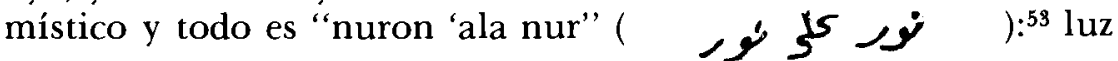
sobre luz, como propone el Corán. Es decir, "Amada en el Amado transformada".

El alma de San Juan y de los sufíes ha quedado capacitada para esta unión transformante porque se ha limpiado antes de todas sus impurezas. San Juan alude a ellas una y otra vez en forma metafórica aunque algo esquemática:“"...si hubiésemos de hablar de propósito de la fea y sucia figura que al alma los apetitos puede poner, no hallaríamos cosa, por llena de telarañas y sabandijas que esté ... ni otra cualquiera cosa inmunda y sucia cuanto en esta vida la puede

\footnotetext{
${ }^{53}$ KUBRA, op. cit., 11, p. 4.
} 
haber y se puede imaginar, a que pudiéremos comparar" (VO, p. 383). Pero, eso sí - y como Santa Teresa-, el santo compara en más de una ocasión a esta sensualidad espiritual con "animales" (VO, p. 911). Es una vez más el imaginativo Kubrā quien describe con colorido el motivo alegórico, dando la impresión de que amplifica al más sobrio San Juan pero sin salirse de su línea de pensamiento. La luz de la lámpara de fuego alumbra su alma y el ensayista persa advierte las alimañas o animales de la que está llena y que necesita expulsar para entrar en "quietud". (Recordemos el impacto especial que tiene para un musulmán, acostumbrado a ritos purificados como el de la ablución, la noción de la impureza. Si ciertos animales como el perro "contaminan" un lugar no se debe rezar en él. San Juan - lo hemos visto- parece cerca de esa aguda sensibilidad para lo corrupto que exhibe Kubrä. Sus “alimañas”, que producen una repugnancia difícil de describir, parecerían ser la traducción emocional de estos animales impuros que describe el místico musulmán). Traducimos directamente del árabe:

El dikr (recogimiento) es como una lámpara encendida en una casa oscura...[ante ella el alma] comprendeque la casa está llena de impurezas [: $]^{54}$ como la impureza de un perro, de una pantera, de un léopardo, de un asno, de un toro, de un elefante y de toda criatura objetable de la existencia... (cap. 54, p. 25)

La unión con Dios se ha hecho posible para el autor de la "Llama" y para los iluministas o išraquíes musulmanes por una razón adicional: los velos que cubren y separan a la Divinidad del alma del místico se han eliminado. Como señalan Asín y W.H.T. Gairdner ${ }^{55}$, este símbolo del velo de lo fenomenológico y humano que nos separa de Dios lo esbozan ya los neoplatónicos (por ejemplo, el Pseudo Dionisio en Las jerarquías celestes) y se encuentra presente en renancentistas como Garcilaso y fray Luis. Pero la insistencia de los musulmanes en el símbolo y en la profusa elaboración de éste en poemas y tratados nos permite asociarlo aquí con el Islam, sobre todo, por el contexto concreto en que aparece: como parte del símbolo más amplio de la iluminación espiritual.Algunos islamólogos lo consideran metáfora sufi: "In Soofee parlance, phenomenal existence is conceived by a veil, which conceals the truth from man's view..." comenta T.H. Weir ${ }^{56}$, no sabemos con cuanta conciencia de los lejanos antecedentes alejandrinos. Y es que el símil del velo, muy antiguo en el Islam, aparece ya en tradiciones o hadices como el famoso

\footnotetext{
54 Para aclarar la intelección, suplimos entre corchetes los dos puntos en sustitución de la conjunción "y", , que no es del todo clara en el texo árabe.

55 Prólogo al Mishkāt al-Anwār (The niche for lights) de Al-Ghazzali, London, 1924, p. 44.

56 The Shaiks of Morocco, London, 1909, p. XXXII
} 
Allah hath Sventy Thousand Veils of Light and Darkness: were to withdraw the curtain, then would the splendours of His aspect surely consume everyone who apprehended Him with His sight ${ }^{57}$.

Retoman mảs adelante el símbolo complicảndolo, místicos tan diversos como Simnảní, que coloca el "unveiling" o des-velamiento de Dios en el número 81 de la novena etapa en el camino místico (Bakhtiar, op. cit., p. 96), Kubrả (op. cit., p. 20, 62), Iraqi (M. Smith, The Sufi ...,) Al-Huŷwíri (op. cit., p. 291), Ibn 'Ața' Allāh (Hikam 90), Yami (Smith, ibid., p. 52) Ibn' Arabí, T.A.A., p. 97, 51), Ahmed Algazel, (ibid., p. 108). El hermano de este último, el más célebre Mohammed Algazel - lo señala María Teresa Narváez- ${ }^{58}$ se acerca mucho a San Juan de la Cruz: Dios purga al alma "de las suciedades mundanales y [descorre] los velos que lo ocultan, a fin de que lo contemple con su corazón como si lo viera con sus ojos ... (apud Asín, La espiritualidad ..., II, pp. 515-516). "Rompe la tela deste dulce encuentro!" pide San Juan en la "Llama". En su comentario, nos describe con detalle, y muy "a la sufí", qué cosa sea esta "tela":

...Quítale de delante [Dios al alma] algunos de los muchos velos y cortinas que ella tiene antepuestos para poder ver como El es, y entonces traslúcese y viséase algo entre oscuramente (porque no se quitan todos los velos) aquel rostro suyo lleno de gracias (VO, p. 920).

Velos y cortinas que impiden el encuentro total con Dios: el santo coincide muy de cerca con los musulmanes: en ảrabe hiy $a b$ significa "velo" y "cortina" (Pareja, op. cit., p. 321, A rabic-English dictionary, ed. Cowan, p. 156) y poetas como Ibn al Fảrid aluden a esta última: "...Thou shalt find all that appears to thee / ... but in the veils of occultation wrapt: When he removes / the curtain, thou beholdest none but Him..." (M. Smith, The Sufi..., p. 132). Cortinas y velos separan también, en una versión mảs popularizada, a Mahoma de Dios en la leyenda del $m i^{i} r \bar{a} \hat{y}$ (XIX, 21).

Los paralelos continúan; en el proceso de su purificación que culmina en iluminación, tanto San Juan como los sufíes pulen el espejo de su alma hasta que, bien bruñida, pueda reflejar la luz de Dios: “el espejo [del] corazón se ha pulimentado ya con varias clases de mortificación... cuyo efecto es el pulimento indispensable para que se manifiesten con todo su brillo en el corazón purificado las formas de las realidades místicas" ... Las palabras son del Tabaqat Śa'rani $(11,70)$ de Abū-1-Mawảhib al-Šādilí del Cairo, pero repiten la imagen hasta el cansancio, Rümi, Ibn 'Ața' Allảh, Ibn-' Arabì,

57 Apud Algazel, Niche for lights, prol. de Gairdner, p. 44.

58 "San Juan de la Cruz y Algazel",BAPuL, 2 (1977), p. 85. 
Algazel, y hasta los antiguos Bistamí (m. 874), Hakim Tirmidi (m. 898) y Hasn Basrī (m. 728). San Juan coincide con todos y su alma, "mediante la lumbre derivada sobrenaturalmente" deviene "claro espejo" (VO, p. 459).

De otra parte, Al-Sa'rani explora las misteriosas profundidades de su alma incendiada de amor, que se subdivide en siete estados concéntricos cada vez más profundos (Schimmel, Mystical ..., p. 174). El santo lleva a cabo idéntico descubrimiento al advertir en la "Llama" (I, 13) que su alma es concén trica. Cierto que ya el PseudoDionisio preludió esa concentricidad. Pero San Juan y los sufíes coinciden en sus pormenores. En la glosas al "Cántico" el santo ve que esos grados de concentricidad del alma son precisamente siete:

Esta bodega que aquí dice el alma es el último y más estrecho grado de amor en que el alma puede situarse en esta vida; que por eso la llama interior bodega, es a saber, la más interior. De donde se sigue que hay otras no tan interiores, que son los grados de amor por do se sube hasta este último, y podemos decir que estos grados o bodegas de amor son siete... (VO, p. 700).

Para Santa Teresa - todos los sabemos- son siete los castillos interiores del alma, para San Juan son aquí bodegas vinarias: ¿̇e habrá filtrado en su recuerdo el símbolo del vino extático, también, al parecer, sufí? En la fértil imaginación de Kubrá, las concentricidades del alma se dan en la forma de siete pozos que el alma interior, inflamada de amor, tiene que subir hasta alcanzar la lúz última de la verdad. Traducimos una vez más del árabe:

$Y$ has de saber que [el alma] no tiene una sola existencia. No hay existencia [en el alma] [sin que haya] encima de ella (superımpuesta) una existencia más importante, mejor que [la anterior], hasta que se llega a la existencia de la verdad. Y en cada existencia... hay un pozo [cada existencia es como un pozo] y sus clasificaciones son siete... y si subes los siete pozos de los distintos tipos de existencia [de los que está hecha el alma]... te parecerá [que llegas] a un cielo de la divinidad y del poder y que el amor [de Dios] ... es luz ... y en ella hay tal intensidad que no la pueden resistir las almas y sin embargo aman absolutamente [con este amor supremo] (op. cit., cap. 8, p. 17).

El alma como pozo interior no es imagen privativa de Kubrá, por más curiosa que nos parezca. Tiene larga estirpe musulmana -pensemos, por ejemplo, en Naŷm Rázi, sufí del siglo XIII que también la utiliza (cf. Corbin, L'homme. . ., pp. 156-157). Pero pocos sacan tanto partido al símil como este tratadista persa tardío. En un

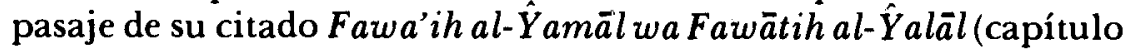
17, p. 8) lo sorprendemos en un interesantísimo y altamente significativo juego de palabras con la raíz árabe 
múltiples sentidos explota y coloca en un primer plano:

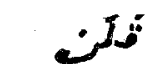
(qalaba $)=$ "to turn around, to transmute, to reflect something;, to be transformed, to change";

(qalb) = "transmutation";<smiles>[C+]1=C[CH+]C1</smiles>

(qalb) = en su sentido más usual de "essence, heart, center, middle", y, por último, la variante قر (qalib) = (pozo) (Arabic-English dictionary, pp. 784-785). Kubrá advierte, pues, en el corazón iluminado del místico, los matices de su posibilidad de reflejar (a Dios), de transmutarse o de transformarse en El, de constituir esencia y centro más profundo del alma y de ser, por último-y metafóricamente- un pozo. El ingenio de este maestro del estilo resulta doblemente importante porque coincide una vez más -y con sorprendente exactitud - con San Juan de la Cruz. El santo -como si conociera las posibilidades de la raíz árabe- equivale también en la "Llama" (VO, p. 875) al centro más profundo de su alma, capaz de reflejar a Dios y de transformarse en Él, con un pozo: "¡oh dichosa alma!... que eres también el pozo de aguas vivas ..." Como el persa, San Juan insiste en la imagen, que repetirá, respaldándola con el pasaje bíblico de la cisterna de Jeremías (VO, p. 875). Kubra había respaldado su propia equivalencia con el pasaje coránico de José (cap. 12, p. 8). Igualmente interesante es una coincidencia adicional, también bastante extraña: al utilizar la imagen del alma como pozo o cisterna en medio de un proceso de iluminación, ambos místicos - como tantos sufíes previos- unen y confunden las aguas "vivas de ese pozo espiritual con las llamas de la transformación en Dios". El pozo del alma de Kubrā "se métamorphose en puits de lumière" (Corbin, L'homme..., p. 121). En San Juan, agua y fuego se equivalen a un milagro que duplica el de la transformación de la Amada en el Amado:

De manera que estas lámparas de fuego son aguas vivas del espíritu...aunque eran lámparas de fuego, también eran aguas puras y limpias...Y así, aunque es fuego, también es agua; porque este fuego es figurado por el fuego del sacrificio que escondió Jeremías en la cisterna, el cual cuando estuvo escondido era agua, y cuando le sacaban afuera para sacrificar era fuego (2 March 1, 20-22; 2 1-22)...antes las llama lámparas que aguas, diciendo ;oh lámparas de fuego! Todo lo que se puede en esta canción decir, es menor de lo que hay, porque la transformación del alma en Dios es indecible (VO, p. 875-6).

Otra modalidad del proceso de iluminación en la que tanto San Juan como los sufíes insisten es la metáfora del relámpago súbito para indicar la manifestación abrupta aunque fugaz de Dios. Aunque en este caso la equivalencia parece bastante extendida (Mircea Eliade indica que "the rapidity of mystical illumination has been compared in many religions to lightning" (The two..., p. 22) entre los musulmanes, incluyendo los alquimistas (cf. Jung, op. cit., p. 317), se convierte en una equivalencia técnica obligada. Ibn-'Arabi 
nos garantiza la estabilidad de su imagen, llamada en árabe la'ih (literalmente, relámpago): "The author of these poems always uses the term "lightnings" to denote a centre of manifestation of the Divine Essence" (T.A.A., p. 92). Una vez más Simnani le da sitial numérico preciso en la vía mística: los relámpagos ocupan el número 69 de la novena etapa del camino (Bakhtiar, p. 96). Muchos otros musulmanes emplean el término, pero acerquémonos sólo al caso de Algazel, que en su Ihy $\vec{a}^{\prime}$ comenta:

... las luces de la verdad brillarán en su corazón ... Al principio serán como relámpagos fugaces, que vuelven a repetirse y a permanecer poco o mucho ... y habrá varias iluminaciones, o siempre la misma... (Apud Pareja, p. 294).

Muy cerca de Algazel, San Juan elabora la experiencia mística súbita bajo la metáfora del relámpago:

Y es, a veces, como si le abriese una clarísima puerta y por ella viese [el alma una luz] a manera de relámpago, cuando en una una noche oscura súbitamente esclarece las cosas y las hace ver clara y distintamente y luego las deja a escuras ... (VO, p. 459).

Hasta aquí el relámpago místico. No vamos a insistir demasiado en una imagen semejante que San Juan comparte con los musulmanes -el rayo de tiniebla (Noche, L 2, C. 6, 3; VO, p. 572)-porque aquí el antecedente común de ambos (posiblemente el PseudoDionisio) es bastante evidente. Es útil consignar, sin embargo, que este "rayo de tiniebla" es parte de una metafísica de luz y sombra que, si bien es compleja ya en el primitivo Padre de la Iglesia, entre los sufíes - sobre todo los persas - adquirirá dimensiones insospechadas de complicación e ingenio, como explora agudamente Toshihiko Izutzu en su ensayo "The paradox of light and darkness in the garden of mystery of Shabastari" (Anagogic qualities of literature, Univ. Park, Pa., 1971, pp. 288-307). Hasta los arquitectos de las mezquitas jugarán con esa alternativa de luz y sombra. Sorprenderemos en San Juan - ya algo lejos del Pseudo-Dionisio- el mismo juego con el claroscuro, para el que inventará un término: "obumbraciones" o "hacimiento de sombra" (VO, p. 878). Su curiosa elaboración del caleidoscópico fenómeno espiritual parecería colocar a San Juan de la Cruz cerca de la mística musulmana y de la estética árabe, que, en pleno desafío a la lógica aristotélica, tanto disfruta de la imposible unión de los contrarios:

...como quiera que estas virtudes y atributos de Dios sean lámparas encendidas y resplandecientes, estando tan cerca del alma ... no podrán dejar de tocarla con sus sombras, las cuales también han de ser encendidas y resplandecientes al talle de las lámparas que las hacen, y así estas sombras serán resplandores ... (VO, p. 878). 
El poema de la "Llama" con sus correspondientes glosas, en el que San Juan describe el proceso de su iluminación final, siempre ha resultado de los más enigmáticos del santo y de los menos trabajados por la crítica. El referente de la literatura iluminista musulmana parece ayudarnos a ir descifrando su misterio y a ir familiarizándonos con algunas de sus posibles fuentes. Fuentes sufíes a las que el santo parecería en alguna manera, directa o indirectamente, haber tenido algún acceso. No ponemos en duda la ortodoxia y las intenciones cristianas de San Juan. Pero el poeta, al coincidir en tal manera con los sufies, incluso al adaptar tan a menudo sus propios apoyos bíblicos a la simbología técnica musulmana, aunque hijo innegable de Occidente, deviene también, y en más de un sentido, hijo cultural de Oriente. Hijo genial, en el fondo, de la España de tres castas que exploró Américo Castro, el poeta canta sus sentimientos cristianos con metáforas musulmanas. Y su "Llama", poema sin duda ortodoxo aunque culturalmente mestizo, parecería celebrar la morada de la unión iluminativa desde el punto de vista de un israquí o alumbrado musulmán. Más aún: de un israquí muy bien versado en la materia y en la simbología iluminista pertinente.

\section{d) El agua o la fuente mística interior}

Pero este "versado" en la simbología islámica que parecería ser San Juan nos aguarda aun sorpresas adicionales. Otro de sus símbolos preferidos es el agua como fuente interior del alma, que poetiza en la lira 12 del "Cántico" ("Oh cristalina fuente / si en esos tus semblantes plateados / formases de repente/los ojos deseados / que tengo en mis entrañas dibujados") y en el poema "Cantar de la alma que se huelga de conocer a Dios por fe", que comienza "Que bien sé yo la fonte que mana y corre / aunque es de noche". La universalidad del agua como metáfora espiritual es evidente, desde la Biblia (Juan 4:14) hasta la terminología alquímica (Jung, op. cit., p. 104). Incluso la fuente, "símbolo inmemorial de vida eterna" como la llama con sobrada razón María Rosa Lida en su erudito ensayo "Transmisión y recreación de temas grecolatinos en la poesía lírica española" ( $R F H, 1,1939,20-63)$. Al explorar las modalidades particulares que el símbolo adquiere en manos de San Juan, encontramos una vez más rasgos que parecerían concretamente musulmanes. Algunos de ellos ya los señaló Asín Palacios: tanto San Juan como Santa Teresa emplean la imagen islámica — sobre todo šádili- ${ }^{59}$ de la oración o meditación trabajosa vista en términos del acarreo difícil del agua espiritual por medio de caños y arcaduces, esfuerzo que contrasta

${ }^{59}$ Cf. También Algazel, Ihlyā pp. 211-212, y Rūmi, que nos habla asimismo del agua del alma acarreada por canales (SCHIMMEL, op. cit., pp. 80 y 85 ). 
con la espontaneidad del manantial autónomo de un grado más alto de contemplación "... en poniéndose en oración, ya como quien tiene allegado el agua bebe sin trabajo en suavidad, sin ser necesario sacarla por los arcaduces..." Dirá San Juan en la Subida (L II, XV; VO., p. 421). Está muy cerca de él Santa Teresa en el Libro de su vida (XIV) y en el Castillo interior.

El símbolo de la fuente en San Juan ha sido objeto de numerosos estudios de parte de la crítica, que han hallado dificultad en trazar sus orígenes. No parecen bíblicos para David Rubio:

Ninguna de las 56 metáforas de la "fuente" de la Vulgata, ni ninguna de las numerosas metáforas del mismo objeto, de la mística occidental, puede en modo alguno relacionarse con el concepto de la "fuente" en San Juan de la Cruz (La fonte, La Habana, p. 18).

Ludwig Pfandl (Historia de la literatura nacional española en la en la edad de oro, 1933) asocia la fuente sanjuanística a la fuente "della prouva dei leali amanti" (p. 108) del libro de caballerías de Platir. Dámaso Alonso, en cambio, en su indispensable La poesía de San Juan de la Cruz. (Desde esta ladera), rechaza, por razones principalmente bibliográficas, la posible influencia del Caballero Platiry favorece la de la Égloga II de Garcilaso a través de la divinización de Sebastián de Córdoba. María Rosa Lida, al reseñar el libro del maestro, resta importancia a Sebastián de Córdoba y enfatiza la cercanía de San Juan a la fuente del Platir (pese a lo problemático de su posible influencia) y a la de Primaleón. La erudita entiende como elemento esencial del símbolo el hecho de que la fuente de San Juan refleja un rostro ajeno, tal y como sucede en estas narraciones caballerescas, en la Égloga I de Garcilaso, en la Arcadia de Sannazaro y aun en un epigrama de Paulo el Silenciario.

Sin rechazar estos posibles antecedentes greco-latinos y europeos (de alguna manera podrían haber dejado sus huellas en el reformador), cabe señalar que no aclaran del todo la problemática fuente del santo. Sebastián de Córdoba diviniza el símbolo pero no se detiene en pormenores que lo hagan concidir más estrechamente con el de San Juan. Otros autores (recordemos a Garcilaso) aunque se encuentran más cerca de algunos aspectos esenciales de la fuente (el hecho de que refleje un rostro ajeno) carecen del sentido místico obvio en San Juan. De otra parte, el manantial del santo refleja los ojos del Amado, no el rostro.

La literatura mística musulmana no resolverá todos los espinosos problemas de la fuente del santo, pero nos dará pistas que consideramos fundamentales. La primera, que ya la fuente está claramente concebida "a lo divino". El arabizado Raimundo Lulio nos habla de un espejo cristalino que refleja el grado de contemplación que el alma tiene de Dios, (cf. Helmut Hatzfeld, Estudios 
literarios sobre mística española) y en el Futūhāt (II, 447) de Ibn-c Arabi la fuente es un espejismo (sa ra $\vec{a} b$ ) que el místico sediento cree ver, y, al advertir su error, descubre en cambio a Dios y a sí mismo (cf. Asín, El Islam ..., p. 497). Recordemos que los "semblantes plateados" reflejan los ojos que San Juan tiene "en sus entrañas dibujados". Es decir: lo relfejan a él y a Dios.

Detengámonos un momento en el citado poema "Qué bien sé yo la fonte...", compuesto en la cárcel de Toledo hacia 1577-1578 y uno de los más estremecedoramente hermosos de San Juan. Allí el poeta nos va explicando su "fonte" y muchos de los elementos descriptivos (salvo el final, mucho más marcadamente cristiano) parecerían estar incluidos en este comentario que, siguiendo casi ad pedem litterae el Book of Certainty (p. 27), hace Bakhtiar del símbolo sufi de la fuente mística:

The mystic enters the Garden of the Spirit and finds a fountain, water which gushes forth ... ["flowing", en el Book if Certainty, p. 36; "fonte que mana y corre" en San Juan] ... "the fountain is the Fountain of Kanowledge" ["que bien sé yo" es el estribillo del poeta]..." which is illuminated by the Spirit. It is the contemplative Truth of Certainty, the knowledge of Illumination ... [San Juan dirá de su fuente, también curiosamente encendida: "Su claridad nunca es escurecida, y sé que toda luz de ella es venida"] ... "knowledge of the Onenness of all Divine Qualities", [San Juan insiste en la unidad, aunque se refiere a la que subyace en el misterio de la Trinidad: "Bien sé que tres en una sola agua viva / residen, y una de otra se deriba"] ... "The Fountain of Knowledge appears like veils of light, not darkness, behind each of which shines the Light of Essence Itself". [En los "semblantes plateados" de la fuente del "Cántico", que San Juan entiende como "fe" se entrevé a Dios aun a través de velos": a la postre de esta fe, quedará la sustancia de la fe, desnuda del velo de esta plata ... De manera que la fe nos da y comunica al mismo Dios, pero cubierto con plata de fe ...]" (VO, p. 657).

San Juan "aunque es de noche" insiste en la certeza mística que siente ante esta fuente. Repite nada menos que once veces el verbo saber en el poema, enfatizándolo casi invariablemente: "que bien sé yo". Esa misma certeza en la que insisten, como vimos, el Book of Certainty y la estudiosa Bakhtiar, es el referente semántico principal del símbolo sufí de la fuente. Entre otros místicos, dice Algazel en su Nicho de las luces al comenzar la azora coránica 13, 19: "the water here is knowledge" (p. 77). Lo sabe desde el siglo Ix Nūri de Bagdad: en el Tratado VII de su Maqāmātl al-qulüb (p. 135), en el que dedica largas descripciones al agua mística del alma, afirma que la que fluye en el corazón del gnóstico implica el conocimiento ( علو p ) de los secretos de un Dios eterno (recordemos a San Juan): "aquella eterna fonte está escondida" (VO., p. 930). El agua divinal también simboliza para Nūri la certeza de ese conocimiento de Dios. 
Pero San Juan matiza esa certeza: "que bien sé yo por fe la fonte frida" (VO., p. 931). La "cristalina fuente" del "Cántico" significa igualmente la fe, según explica el poeta en sus glosas al poema (VO, p. 657). Esa delicadísima conjunción de fe y de certeza se da también entre los sufíes. Leemos en el Book of Certainty que el tratadista describe en esos mismos términos la "Fountain of the Lore of Certainty": "This degree of certainty being none other than faith (imän) ... (p. 145). En otro pasaje, determina que el segundo grado de la fe en el sufismo es el del 'Eye of Certainty" (cainu'l-'yaqin) (p. 13). Ya ésta terminología parecería más obstrusa y extranjera. Pero no: nos acerca aun más a la complicada fuente de San Juan.

En la fuente del "Cántico", exarcebando sin duda la leve asociación de la Égloga II de Garcilaso ("¿Sabes que me quitaste, fuente clara / los ojos de la cara?") San Juan ve que se reflejan "los ojos deseados" del Amado. Curiosa, misteriosamente, sus ojos, no su rostro. Esta hermosa lira de la fuente parece preceder en el "Cántico" el momento mismo de la unión. Para Kubrā, lo mismo: "le double cercle des deux yeux" aparecen "au stade final du pèlerinage mystique" (Corbin, L'homme ..., p. 127). Esos ojos pueden herir al místico próximo a la unión total. Lo mismo advierte Sabastari: "the eye has no power to stand the dazzling light of the sun. It can only see the sun as reflected in the water" (apud Izutzu, op. cit., p. 298). Acaso por esa misma razón San Juan pide primero contemplar esos ojos alegóricos en su "cristalina fuente": sólo así, y como sus colegas de experiencia sufíes, los podrá resistir. El misterio de la lira parecería irse resolviendo a la luz de estos paralelos tan estrechos. Cuando en la estrofa siguiente el alma del poeta "va de vuelo" hacia Dios, "no lo puede recibir sin que casi le cueste la vida" (VO, p. 660) y exclama: “'Apártalos, Amado ...! Qué cerca se coloca San Juan de lbn-'Arabi, que al comentar el enigmático verso del Ta-rrŷuman "She kills with her glances" explica que se refiere "to the station of passing away in

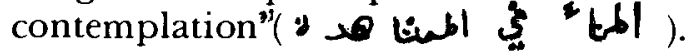

La insoportable agonía del éxtasis prefigurada en unos ojos divinos cuya mirada apenas se resiste parecería que hace coincidir una vez más al santo y a sus correligionarios de Oriente. En ambos casos piden los ojos de Dios para quedar capacitados para ver a Dios: "Cuando tú me mirabas, / su gracia en mí tus ojos imprimían: / ...y en eso merecían / los míos adorar lo que en tí vían" (VO, p. 628) exclama San Juan, cercano sin duda a tantos musulmanes como Ibn-c Arabi: "Cuando aparece mi Amado ¿con qué ojo he de mirarle? Con el suyo, no con el mío, porque nadie le ve sino Él mismo (apud Nicholson, Poetas ..., p. 198).

Recapitulemos lo dicho hasta ahora. San Juan -como los sufíes entrelaza el símbolo de la fuente con el de los ojos, que vemos reflejados en las aguas plateadas del manantial. Pero la asociación gana en profundida cuando recordamos que el reformador entiende 
en sus glosas que la fuente simboliza la "fe" y que los ojos que se reflejan allí y que tiene en sus entrañas "dibujados" significan las verdades divinas "encubiertas en fe" (VO, p. 658). No se conoce a Dios directamente, sino dibujado y reflejado a través de la fe". Tenemos pues que tanto la fuente como los ojos significan lo mismo: la "fe". Los términos, identificados, resultan intercambiables: fuente $=$ ojos. San Juan insistirá en esa identidad al repetir la equivalencia ojo = "fe" en otro pasaje del "Cántico", derivativo sin duda del problemático verso 9 del Cantar de los cantares: "en uno de mis ojos te llagaste" 60 . Dice el santo: "entiéndes aquí por el ojo la fe..." (VO, p. 716). Ojo y fuente, que significan lo mismo una y otra vez, quedan semánticamente equivalidos y constantemente asociados por San Juan. Curioso, pues el Senequita de Santa Teresa parecería conocer otro secreto de los sufíes. Más aún: de la lengua árabe. Una de las razones por las que los místicos musulmanes asocian tanto la fuente con los ojos (o el ojo) es sin duda porque en árabe la raíz 'ain ( بs ) significa, simultáneamente, ojo y fuente. De ahí, nuestra frase castellana "ojo de agua". De ahí también, quizá, y como herencia cultural más difícil de desentrañar, el ojo y la fuente sanjuanística en enigmática unión.

\section{c) La subida del monte}

Uno de los símbolos más famosos de San Juan - si no uno de los más elaborados - es la subida de un monte - el Carmelo en su caso- que significa para él el ascenso a la cumbre mística del alma. Pocos símbolos habrá tan "jungíanos" como este de la célebre montaña cósmica cuyos ecos encontramos en el santo: desde los zigurats de Mesopotamia hasta el templo de Borobudur en Java (Eliade, p. 317) estamos ante una arquitectura metafórica que hace posible una ascención ritual y concreta de profundo sentido espiritual. Como era de esperar, la literatura mística recogerá el motivo simbólico, que podemos documentar repetidas veces en Europa en el Neunfelsenbuch (Libro de las nueve rocas) del místico germano del siglo XIV Rulman Merwin, en Gerson, en las Meditaciones del amor de Dios de Diego de Estella, en el Beato Nicolás Factor, en el Tercer abecedario espiritual de Francisco de Osuna, y, sobre todo, en el más conocido Bernardino de Laredo, cuya Subida del Monte Sión parecería preludir la Subida sanjuanística ${ }^{61}$.

${ }^{60}$ El "ojo del alma", utilizado como símbolo por tantos espirituales como San Agustín (Confesiones, X) y Meister Eckart, es tambien - y en su forma singular - un órgano del conocimiento espiritual para los musulmanes. " Aim al-qalb" lo llama Algazel (Ihyáa, p. 428) y el autor del Book of certainty, como ya hemos dicho, "ain'l-yaqin" (ojo de la certeza). También Ibn-'Abbâd de Ronda manejará el símbolo en términos semejantes en su Hikam 243.

61 Cf. SANtiago BarRoso, La "Subida del Monte Sión" y la "Subida del Monte Carmelo", Murcia, 1970. 
No es de extrañar que en la mística musulmana - por una razón u otra- el símbolo reciba también esmerada atención. La montaña a cuya cumbre el místico se esfuerza por llegar es parte de una geografía visionaria de mapas imposibles pero muy articulada que estudia a fondo Henri Corbin: en el Récit de l'éxil de Suhrawardi la “orientation est celle d'une géographie visionaire s'orientant sur le "climat de l'Âme" (L'homme ..., p. 70). Desde el Libro de la escala de Mahoma (cf. Muñoz Sendino, pp. 225-226) hasta el Tarŷumān de Ibn-"Arabì encontraremos la elaboración teórica de la montaña espiritual. Kubrá insistirá mucho en ella, denominándola con un nombre técnico muy socorrido: la montaña del $C a \vec{f}$.

Nos hemos detenido en un símbolo tan universal para consignar que en algunos detalles de su particular elaboración San Juan nos vuelve a recordar a sus predecesores sufíes. La Subida espiritual de Bernardino de Laredo es al Monte Sión que será uno de los montes que también nombra San Juan (Sub. L. 3, c 42.5, VO, p. 533). Parecería una elaboración cristiana de la alegoría, pero nos encontramos con la sorpresa de que siglos antes la mística musulmana elaboró la imagen de una subida a ese mismo Monte Sión o Sinaí (recordemos que el Corán hereda mucho de las Escrituras y que ese monte también le es sagrado al Islam).

Un obscuro tratadista ismaelita, al comentar el Rosal de los misterios de Sabastari en su Ba'zi azta 'wilä-e Golshan-e-Rāt (Quelques-unes des exégeses spirituelles de la Roseraie du Mystere,en versión de Corbin; Trilogía ..., p. 96) destaca su subida al monte Sión o Sinaí. Más importante aun es el caso de Suhrawardi:

Le symbol du Sinaï, nous le recontrons deja ... dans Sohrawardi [Recit de l'exil occidental] Là même, la figure que le pèlerin découvre au sommet du Sinaï mystique, typifie a la fois sa propre Nature Parfaite (al-Tibâ 'al-Tâmm. . . ). . . Avec cette ascension au "Sinaï de son être", le mystique acheve l'expérience de son escathologie personelle du présent. En révivant l'état de Moïse au sommet de la montagne, c'est le"Moïse de son être" qui est volatilisé (Corbin, L'homme ..., pp. 111-112).

Para nosotros, la coincidencia más interesante entre San Juan y los místicos musulmanes dedicados a elaborar esta subida cósmica en distintos tratados, es que en ambos casos se recurre a grabados o pinturas que ayudan a ilustrar y a explicar doctrinalmente cómo se debe llevar a cabo tan ardua ascención. Las representaciones gráficas de procedimiento místicos, muy comunes en Raimundo Lulio, la asocia Julián Ribera a sus antepasados sufíes antes que a la tradición emblemática europea:

Aquel método didáctico que se tiene como innovación introducida [por Lulio] por el que todo se vulgariza ... con representaciones gráficas, 
con esquemas, círculos concéntricos ..., cuadrados, para que entre por los ojos en la inteligencia de la muchedumbre, era método peculiar y característico de los sufíes musulmanes coetáneos con Lulio ${ }^{62}$.

Si se comparan ambas tradiciones, la verdad es que Lulio, que no leía el latín pero que redactaba en árabe, parece más derivativo de los "morabitos sufíes" que cita directamente en su Libre d'amic e amat que de los emblemistas europeos que tanto estudia Frances Yates. Bakhtiar reproduce un ejemplo concreto de esa larga tradición musulmana que resulta de sumo interés para nuestro estudio: se trata de un grabado o pintura persa de la montaña cósmica del $C \bar{a} f$, que forma parte de un manuscrito que contiene una antología de poemas persas del siglo XIV (véase figura 1). Aunque policromado y más decorado que el famoso grabado de la Subida del Monte Carmelo que conservamos de mano de San Juan (VO, p. 362) y que reelaboran con más artificio sus seguidores (ver figuras 2 y 3 ), la idea fundamental en común no es difícil de advertir. Para San Juan y para los sufíes se trata de un grabado lleno de explicaciones (como se observa en el encuadre superior del grabado persa) que sirve de sostén ilustrativo a poemas místicos sobre la ascención a la montaña espiritual. ¿Estaremos ante un lejanísimo antecedente del procedimiento sanjuanístico que une el grabado al poema y a la explicación doctrinal en prosa al hablar de su monte místico? Algunos pormenores de esta montaña simbólica musulmana tampoco le parecen ajenos al santo. Frithof Schuon (Stations of wisdom, apud Bakhtiar, p. 57) describe el ascenso del sufí a su propia alma en estos términos:

What separates man from divine Reality is the slightest of barriers. God is infinitely close to man, but man is infinitely far from God. The barrier, for man, is a mountain ... which he must remove with his own hand. He digs away the earth, but in vain, the mountain remains; man goes on digging in the Name of God. And the mountain vanishes. It was never there.

San Juan dirá en la cúspide de su monte "por aquí ya no hay camino", y descubre que nunca lo hubo. En el fondo de su alma se encuentra Dios: el santo ha llevado a cabo un viaje circular e inexistente: "de Dios hasta Dios".

Pero el camino no deja de ser arduo por ello. Insiste Bakhtiar: "One needs a guide to climb: one can climb a mountain by many paths, but one needs to follow one made by experienced people ..." (p. 28). Recordemos la obsesión de San Juan con el maestro espiritual, que debía ser el adecuado a cada alma, obsesión que Asín trazó a los musulmanes. Recordemos también los caminos plurales, algu-

62 Opúsculos diversos, Tetuán, 1952, pp. 170-171. 
nos de ellos errados y que por lo tanto no conducen a ninguna parte: aparecen en el esquema sanjuanístico, como podemos ver en la reproducción. Continúa Bakhtiar: "The higher one moves spiritually, the more vision one gains ... one pases from form to formlessness..." (p. 28). Algazel insiste en el mismo proceso: "The fourth stage is to gaze at the union oí an all-comprehensive, all-absorbing One, loosing sight ever of the duality of one's own self. This is the highest stage..." 63 . San Juan vuelve a hermanarse con los espirituales de Oriente por su insistencia en esta nada que es el modo de llegar al todo de la cumbre de este monte: "para venir a serlo todo / no quieras ser algo en nada" dice el poemita que acompaña el grabado. También advertirá como necesaria la aniquilación (la famosa fana) en el proceso de dicho ascenso: "una sola cosa necesaria, que es saberse negar de veras ... y aniquilarse en todo" (VO, p. 495).

$\mathrm{El}$ ascenso al monte de la propia alma, que se logra a través de la autoaniquilación, es, recordémoslo, un motivo místico universal. Sin embargo, San Juan y los sufíes (y aun Bernardino de Laredo) coinciden en su manera común de subir metafóricamente al Sinaí del alma, orientados en su singular aventura por "mapas" místicos.

\section{f) El pájaro solitario}

San Juan concibe al alma como "pájaro solitario" (tal el "passer solitarius" del salmo 101:8 de David) pero le adjudica propiedades enigmáticas que lo conviernte en un símbolo que ha atormentado a críticos como el P. Eulogio Pacho por su total carencia de antecedentes occidentales. En realidad son muy difíciles de encontrar en Europa. Autores que de una manera u otra manejan el símbolo del alma como pájaro (tan viejo que lo tenemos documentado desde el antiguo Egipto), tal San Buenaventura, San Bernardo, Hugo de San Víctor, Lulio, el Beato Orozco, Laredo, incluso textos anónimos medievales como el Libro das aves portugués y el Ancren Riwle (The nun's rule), de una desconocida anacoreta inglesa del siglo XIII, definitivamente no nos son muy útiles a la hora de entender las claves de San Juan. Tampoco nos iluminan en ese sentido estudios sobre el tema del ave literaria como el citado de María Rosa Lida: el ruiseñor y la golondrina renacentistas, de clara estirpe grecolatina, hacen aun más misterioso y singular el pájaro sanjuanístico, del cual, desdichadamente, nos quedan tan sólo dos breves y casi idénticos esbozos, uno en los Dichos de luz y Amor (120, VO, p. 967) y otro en las glosas al "Cántico" (VO, p. 70). El Tratado de las propiedades del pájaro solitario, que tanto nos hubiera iluminado, está, hasta el presente, perdido. Intentaremos, con todo, arrojar alguna luz sobre el esquemático pájaro místico del alma de San juan. Una vez más, las claves más fecundas parecen ser orientales y no occidentales. Los

\footnotetext{
63 SEYD NAWAB ALI, Some moral and religious teachings of Al-Ghazzali, Lahore, 1946, p. 104.
} 
musulmanes - como los cristianos - han utilizado durante siglos el símbolo, que ya adivinamos tiene connotaciones místicas en el Corán, cuando Salomón exclama: "O man, we have been taught the language the birds, and all favours have been showered upon us" (27:15). Sufíes posteriores como Kubrā, adaptando el versículo, exclamarán

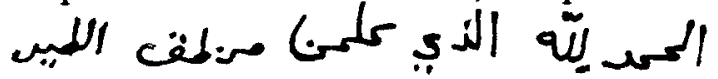

("la alabanza a Dios, que nos dio el lenguaje de los pájaros"). Este es "the language of self [which] contains knowledge of the higher state of being"' (Bakhtiar, p. 37). A lo largo de la Edad Media los tratados musulmanes sobre el pájaro místico se suceden: Saná'í, 'Aț̣ár, Bāyazíd al-Bisțāmí. Son particularmente importantes los tratados que tanto Suhrawardi como Avicena y Algazel compusieron bajo el título de Risalāt al-Tair o Tratado del pájaro, si bien, como indica Seyyed Hossein Nasr (Three ..., p. 51) Suhrawardi prácticamente traduce del árabe al persa el tratado de Avicena.

Pero detengámonos en las claves que los sufíes nos proporcionan para ir descifrando o poniendo en perspectiva los misterios de las "propiedades" del pájaro sanjuanístico ${ }^{64}$. El santo coincide estrechamente con el persa al-Bistami (m. 877), que se auto-describe como "a bird whose body was of Oneness", y que vuela "in singularity” (Attar, Muslim ..., s.p.). Recordemos a San Juan: su pájaro es solitario" y no sufre "compañía de otra criatura" (VO., p. 967). Las alas del pájaro de al-Bistami son "de eternidad" (Schimmel, Mystical ..., p. 49); el pájaro simbólico de Rūmi vuela alejándose de todo lo material y perecedero (Nicholson, Poetas ..., p 86); el de San Juan "ha de subir sobre todas las cosas transitorias" (VO, p. 967). El ave del persa levanta su cabeza hacia el Señor ("Attar, ibid), el del carmelita "pone el pico al aire del Espíritu Santo" (VO, p. 967). Hallāy exclama "I fly with my wings to my Beloved" 65 en el vuelo de San Juan "El espíritu" ... se pone en altísima contemplación" (VO, p. 670). Y ambos terminan por adquirir un conocimiento que trasciende toda razón: el alma de Hallāŷ, como ave metafórica, "fell in to the sea of understanding and was drowned" (Hallāy, op. cit., p. 34), la de San Juan, por ser ave en lo alto del tejado como indica el salmo 102:7, se eleva tanto que "queda como ignorante de todas las cosas, porque solamente sabe a Dios sin saber cómo" (VO, p. 427). Acaso la coincidencia más interesante la tenga San Juan con el

\footnotetext{
64 Existen otres coincidencias entre el símbolo del pájaro místico de San Juan y la de los sufíes. San Juan habla del halcón o ave de caza que es su alma en el poema que tiene por estribillo "Tras un amoroso lance / y no de esperanza falto / volé tan alto / que le di a la caza alcance". Rumi había hecho idéntica ecuación entre su alma y el halcón de caza en su Mantiq ut-Tair (Schimmel, Mystical ..., p. 307). Parecería que San Juan interpreta no solo a lo divino sino "a lo sufí" el motivo temático cetrero de poemas como "Indirecta a una dama" de la Floresta de varia poesía del doctor Diego Ramírez, que con sobrada razón Dámaso Alonso ha asociado al santo.

${ }_{65}$ The Tawasin. The great Sufic text on the unity of reality. Tr. Aisha Abd ar-Rahman al-Tarjumana, Berkeley and London, 1974, p. 34.
} 
pájaro contemplativo de Suhrawardi. La cuarta propiedad que le adjudicaba el santo en sus Dichos al pájaro solitario resultaba sin duda muy extraña: "no tiene determinado color" (VO, p. 907). Muy "normal" para Suhrawardi: tampoco su Simurg, pues "all colours are in him but he is colourless" (apud Nasr, Three Muslim ..., p. 30). En ambos casos lo incoloro implica el desasimiento y vacío de todo lo material en el alma. Las coincidencias son tan estrechas que no cabe sino lamentar una vez más la pérdida del tratado exhaustivo sobre el pájaro solitario de San Juan, que tantas claves adicionales hubiera podido ofrecernos.

\section{g) El combate ascético}

El progreso a lo largo del camino espiritual entendido como un combate contra las fuerzas del mal (demonio, apetitos sensuales, vicios) tiene larga tradición como alegoría mística o moral. El Pseudo Dionisio en sus Jerarquías eclesiásticas nos ofrece un esbozo temprano pero en el fondo distinto de la detallada y hasta pintoresca espiritualidad "bélica", en cuya descripción los místicos peninsulares parecen sobresalir (Lourenzo Justiniano ${ }^{66}$, fray Luis de Granada, fray Alonso de Madrid, Osuna) aunque tenemos casos también en el resto de Europa, como el de Suso. San Juan de la Cruz y Santa Teresa utilizarán como pocos el símil de la lucha espiritual, que parecería culminar, ya con otros matices, en San Ignacio de Loyola.

El Islam elabora el símil de este combate ascético durante los siglos medios, prácticamente en los mismos términos de los espirituales peninsulares. "Los sufíes -explica el P. Félix Pareja-citan con frecuencia la aleya: (Corán 20/31) «y los que lucharon con ardor por nos, los guiaremos por nuestra vía; ciertamente Allah está con los que obran el bien»" (op. cit., p. 229). Pero la estricta aplicación mística o las aleyas coránicas y tradiciones del Profeta no se hacen esperar. La síntesis de Al-Huywiri es perfecta:

The Apostle said: "We have returned from the lesser war (al-jihäd $a l$-asghar to the greatest war (al-jihäd al-akbar) ... What is the greatest war? he replied, "It is the struggle against one's self (mujähadat al-nafs)" (op. cit., p. 200).

Estamos ante el símil de un "javānmardī, c'est-à-dire de «chevalerie spirituelle»” según Corbin ( $L$ 'homme ..., p. 195) que alcanza elaboraciones exquisitas como la de pretender que el Lam-Alif inicial del famoso dictum musulmán "lá illáha illa Alláh" tiene forma de espada - $V$ - y que por lo tanto anuncia y participa dichocombate ascético. Tan familiar va deviniendo la imagen que Ibn Qasyi

\footnotetext{
${ }^{66} \mathrm{Cf}$. MARIO MARTINS, Alegorias, simbolos e exemplos morais da literatura medieval portuguesa, Lisboa, 1975, p. 175.
} 
organiza a sus adeptos en forma de milicia religıosa en una rápita o convento fortificado en Silves (Pareja, p. 381), siglos antes de que San Ignacio viera la luz. Casi todos los sufíes más importantes parecen conocer la alegoría: Algazel en su Ihyā ulūm al-din (cf. Pareja, pp. 293-4 y Nwyia, Ibn' $A t a^{\prime}$ '..., p. 225), Kubrä en su Fawa' ih al Yamal (cf. Corbin, L'homme. . ., p. 99), Ibn-`Arabi en su Tarŷumän al-aswāq.

El combate espiritual se concreta como metáfora en el Islam: "el caballero espiritual" combate desde el castillo de su alma, lleno de torreones y circundado por cercos alegóricos. Parecería que estamos ante una novela de caballerías - de las que tanto leyó Santa Teresa- y "a lo divino". Sólo que estas aun no estaban escritas cuando ya los sufíes alegorizaban el castillo interior de su alma desde, por lo menos, el siglo IX. En la Subida (L 3, c. 20, i, VO., p. 502) San Juan nos habla de "la cerca y las murallas del corazón" pero es la enigmática lira final del "Cántico" la que está sostenida sobre la alegoría de esta lucha victoriosa sobre el demonio en el castillo inexpugnable del espíritu del místico: "Que nadie lo miraba / Aminadab tampoco parecía / y el cerco sosegaba / y la caballería / a vista de las aguas descendía".

En sus glosas, San Juan nos aclara un poco el misterio verbal del cierre del poema, que produce la impresión de ser anti-climático. Aminadab "significa el demonio (hablando espiritualmente) adversario del alma” (VO, p. 783): es una extraña equivalencia para la que el santo cita con despropósito el Cantar de los cantares (6:11) y que cree el P. Sullivan puede proceder de una exégesis de San Gregorio. El comentario pone de relieve los detalles de esta batalla espiritual: "[Aminadab] "combatía y turbaba siempre [al alma] con la innumerable munición de su artillería, para que ella no se entrase en esta fortaleza, y escondrijo de el interior recogimiento con el Esposo..." (ibid).

Pero el alma ya está en contemplación y "el demonio no solamente no osa llegar, pero con grande pavor huye muy lexos y no osa parecer..." (ibid.) Por eso el cerco - evidente aditamento del castillo- "sosegaba": "Por el cual cerco entiende aquí ... las pasiones y apetitos del alma, / los cuales cuando no están vencidos y amortiguados la cercan en derredor, combatiéndola de una parte y de otra..." (VO, p. 738). Y la caballeria -otra imagen guerrera- que al descender a vista de las aguas tanto misterio añade a la lira, no significa sino los "sentido corporales de la parte sensitiva" (VO, p. 738) que descienden y sosiegan a vista de las aguas o bienes y deleites del alma en el estado de la unión total.

Por más pormenorizada que resulta la explicación del santo a sus versos, si no nos es familiar la alegoría del combate ascético, nos resultaría en exceso misteriosa y forzada. El contexto islámico la va poniendo, sin embargo, en una perspectiva más familiar. Detengá- 
monos en un pasaje del Kitāb-al-Tanwir fi isqät al Taqdir de Ib-'Ata' Alláh de Alejandría (m. 1309):

...las moradas de la certeza mística y la luz que a todas ellas inunda aseméjanse a los muros o cercos que rodean la ciudad y a sus castillos. Los muros son las luces y los castillos son las moradas de la certeza mística, que circundan la ciudad del corazón. Para aquel cuyo corazón está rodeado por el muro de la certeza y cuyas moradas, que son los muros de las luces a la manera de castillos, están íntegras y firmes, no tiene Satanás camino para llegar a él ni en su casa encuentra habitación en qué reposar ${ }^{67}$.

Aunque las equivalencias no coinciden siempre con exactitud con las del santo, los elementos fundamentales se repiten: el corazón como fortaleza o ciudad murada, los cercos. Sobre todo, en este preciso momento espiritual, Satanás no tiene acceso al alma.

Insistamos en ello, porque la huida de Satanás al final del "Cántico" podía parecer dislocada del contexto poético, ya que en liras muy anteriores se había consumado la unión extática y el demonio no podría haber estado presente entonces. Sin embargo, y de manera, como dijimos antes, algo "anticlimática", San Juan nos anuncia justo al final de su poema que Satanás ha sido vencido. Si atendemos a referentes sufíes, el tal "anti-clímax" del poema deviene grand-final: la ausencia total del demonio enemigo del alma marca para los espirituales musulmanes el grado óptimo y último del éx tasis: es la garantía absoluta de las alturas espirituales a las que ha llegado el alma. La lira final del "Cántico" implicaría, así, una verdadera culminación poética y mística. Veamos cuán cerca parece San del Šarh Hikam II, 78 de Ibn 'Abbād de Ronda:

...el sujeto ha perdido la conciencia de su propio ser y conserva tan sólo la de su presencia con su Señor; y quien en tal estado se halla es ya de los que se ven libres de todo mal y peligro, porque sobre ellos ya no tienen poder alguno el enemigo maldito, y el que está libre del dominio del enemigo durante su oración, no necesita trabajar para combatirlo y rechazarlo, y así, su oración va acompañada de la presencia de Dios, ... De modo que, habiendo perdido el devoto la conciencia de sí mismo y estando ya libre de la tentación de su enemigo, tiene que sentir el colmo de bienestar y el máximo deleite, realizándose así en él con toda verdad lo que significa la palabra consuelo ... Por eso decía el maestro contemplativo Abu Muhammad 'Abd al-Aziz de Mahdiyya: "El consuelo espiritual no existe para el que lucha con sus pasiones ni para el que combate a Satanás, sino que tan sólo existe para quien ya está libre y tranquilo de ambos peligros. (Asf́n, "Śădilies", AlAn, 13 (1948) pp. 4-5).

${ }^{67}$ Asf N PALACIOS, "El símil de los castillos y moradas del alma en la mística islámica y en Santa Teresa", AlAn, 2 (1937), pp. 263-264. 
Advirtamos el énfasis en la tranquilidad, consuelo y bienestar final, que repite el santo en los tres últimos versos del "Cántico" y en sus glosas correspondientes. Algazel insistirá en ello: "huirá defraudado Satanás y sin esperanza ya de turbar ... tu intuición unitaria ... (Asín, La espiritualidad ..., t. 3, p. 361). Nüri de Bagdad, desde el siglo IX, y una vez más dentro del contexto de la metáfora del combate ascético que el alma lleva a cabo desde sus castillos o fortalezas interiores, coloca también afuera a Satanás, que ladra inútilmente sin conseguir acceso: "Satanás ... ladra desde fuera de este castillo como ladra el perro" (Maqāmāt ..., VIII, p. 136):

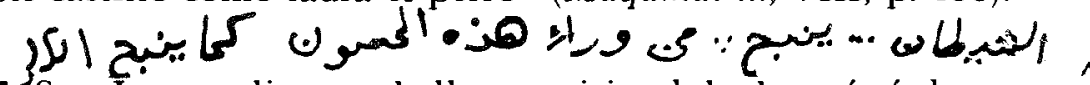

- San Juan, valiente caballero espiritual, lucha más árduamente aun. Se nos antojaría un Amadís espiritual cuando batalla contra una bestia infernal a manera de dragón con siete cabezas:

Dichosa el alma que supiese pelear contra aquella bestia del Apocalipsis $(12,3)$ que tiene siete cabezas, contrarias a estos siete grados de amor, con las cuales contra cada uno hace guerra, y con cada una pelea con el alma en cada una de estas mansiones en que ella está exercitando y ganando cada grado de amor de Dios. Que, sin duda, que si ella fielmente peleare en cada una y venciere, merecerá pasar de grado en grado y de mansión en mansión hasta la última, dejando cortadas a la bestia sus siete cabezas, con que le hacía la guerra furiosa ...Y así es mucho de doler que muchos, entrando en esta batalla espiritual contra la bestia, aun no sean para cortarle la primera cabeza negando las cosas sensuales del mundo; y ya que algunos acaban consigo y se la cortan, no le cortan la segunda, que es las visiones del sentido de que vamos hablando. Pero lo que más duele es que algunos, habiendo cortado no sólo la segunda y primera, sino aun la tercera - que es acerca de los sentidos sensitivos interiores, pasando del estado de meditación, y aun más adelante-, al tiempo de entrar en lo puro del espíritu los vence esta espiritual bestia, y vuelve a levantar contra ellos y a resucitar hasta la primera cabeza, y hácense las postrimerías de ellos peores que las primerias en su recaida, tomando otros siete espiritus consigo peores que él (CLC 11, 26; VO, p. 416).

Pero una vez más, la caballería "a lo divino" de los sufíes incluye la figura de un valiente caballero místico que lucha precisamente contra un dragón - a veces, precisamente de siete cabezascuya representación gráfica - debidamente comentada en persavemos en la miniatura de un manuscrito persa de Sah Nameh (figura 4). En el mismo manuscrito vemos otra ilustración (5) en la que el caballero espiritual, con hermosa montura y lujoso atuendo de ropas, se presenta en plena batalla contra los espíritus malignos -que entorpecen su camino místico. Estos “alyines" o genios de estirpe coránica semejan monstruosos animales o sabandijas que eluden una fácil descripción: contra semejantes criaturas -recordémoslo- también batallaron heroicamente San Juan y Santa Teresa. 


\section{h) El alma como jardín místico}

Otra imagen, muy extendida sin duda en la mística europea, pero en la que San Juan y los sufíes vuelven a coincidir én ciertos detalles fundamentales, es la del alma en estado de unión concebida como jardín o huerto florido. Este jardín, "the unitive station" (T.A.A., p. 65) المقام البامع codifica como pocos Nüri de Bagdad, que dedica varios capítulos de su citado Maqāmāt al-qulüb a describir sus maravillas: flores, lluvias, olores, vientos ${ }^{68}$. San Juan también encontrará estos delicados elementos alegóricos en el "huerto" (C. 24.6, VO, p. 677) que es su alma. Los vientos que orean el espíritu extático del poeta, heredados de las versiones españolas del Cantar de los cantares - el cierzo y el ábrego- adquieren en las glosas un nivel místico a menudo reconociblemente islámico. Su austro, que ayuda a abrir las flores y derrama su olor, "es el Espíritu Santo ...que, cuando este divino aire embiste en el alma, de tal manera la inflama toda ...y aviva y recuerda la voluntad y levanta los apetitos que antes estaban caídos y dormidos al amor de Dios..." (VO, p. 676). Está muy cerca del viento que se esparce por el alma de Sadí: "It's natural for plants to be revived by the morning breeze, whereas minerals and dead bodies are not susceptible to the Zephyr's influence. (The meaning is that only those hearts which are alive to the meaning of spiritual love, can be quickened by the breath of Divine Inspiration"; Smith, The Sufi..., p. 113$)^{69}$. Los olores que estos vientos divinales avivan son Dios y el alma en unión para San Juan: "la misma alma ... que ... da olor de suavidad al Amado que en ella mora" ... "los divinos olores de Dios" (VO., p. 678). Tras establecer la misma equivalencia, Nürí celebra el olor indescriptible del jardín o alma en unión mística: "Dios alabado sea sobre la faz de la tierra - [tiene] un jardín. Quien huele su olor no tendrá deseos del paraíso. Y este jardín es el corazón del místico" (Maqāmät, IV, p. 134). En el jardín también encontramos agua que fluye. No podía no haberla para la sed secular de un árabe. "The Garden of the Soul ... contains a foundation, flowing water ..." (p. 30), comenta Bakhtiar de esta agua que fluye y que tanto celebra Nūri en su tratado. Agua que también pormenoriza y explica en términos divinales el santo carmelita, que descubre su alma "hecha toda un paraíso de regadío divino" (Llama 3,7; VO, pp. 873-4).

Las flores no pueden faltar en el ámbito de este jardín privilegiado. San Juan, recordando pasajes aromáticos del Cantar de los cantares, entiende que el Amado se une al alma "entre la fragancia destas flores" (VO, p. 678). En un pasaje más detallado de las glosas

\footnotetext{
${ }^{68}$ En Rümi, también "The breeze ... is a fitting symbol of the life-giving breath of the Beloved" (SCHIMMEL, The triumphal ..., p. 86).

${ }^{69}$ Cf. también SCHIMMEL, The triumphal ..., p. 203.
} 
al "Cántico", pormenorizará estas flores: el lirio, la azucena, el jazmín, las rosas: cada flor le entrega una dimensión distinta del conocimiento de Dios en el que el alma se va transformando. Para Ibn- 'Arabi la morada mística de la que hablamos es fácil de reconocer: "the flower ... i.e. the station of Divine Revelation..." (T.A.A., p. 101). Las rosas son, para San Juan, concretamente, "las extrañas noticias de Dios" (C. 24.6; VO, p. 694). Aquí sólo faltaría el ruiseñor, que liba la rosa, y que es para los sufíes, en uno de sus símbolos más célebres, la manifestación de la gloria de Dios que el ave mística liba sin cesar (Schimmel, Mystical ..., p. 306).

\section{i) La azucena del dejamiento.}

Hay una flor que San Juan celebra en otro poema y que merece unas palabras adicionales. El poeta culmina los versos de su Noche con el dejamiento final: "dejando mi cuidado / entre las azucenas olvidado". Si atendemos a posibles referentes verbales musulmanes, el grand final del poema quedaría subrayado y la elección de esa flor específica parecería más artística e intencional. San Juan, lo sabemos, no concluye el comentario al poema. Pero las azucenas son precisamente la flor del dejamiento para los sufíes que han alcanzado la etapa mística última donde falla todo lenguaje. En ellos, la azucena, "brethless with adoration" en palabras a Annemarie Schimmel (Mystical ..., p. 308) glorifica a Dios en silencio con las diez lenguas forzosamente mudas de sus pétalos.

\section{j) Las raposas de la sensualidad y el cabello como "gancho espiritual"}

Por último, otros símbolos en común. San Juan - lo vamos advirtiendo - obtiene en buena medida su vocabulario de la Escritura (sobre todo del Cantar de los cantares) pero cuando lo eleva a nivel simbólico-místico lo hace muy a menudo desde parámetros reconocibles dentro del "trobar clus" sufí. El santo equivale las raposas del "Cántico" a los apetitos sensuales del alma (VO, p. 673). Parecería que islamiza el animal bíblico que la Esposa de los Cantares pide que cacen: para sufíes como Mohamed ibn Ulyan las raposillas o zorrillas pequeñas son su nafs o sus apetitos carnales que debe igualmente reprimir durante su camino espiritual:

In my novitiate, when I had become aware of the corruption of the lower soul and acquainted with its places of ambush, I always felt a violent hatred of it in my heart. One day something like a young fox came forth from my throat, and God caused me to understand that it was my lower soul (Al Huŷwiri, op. cit., p. 206) ${ }^{70}$.

${ }^{70}$ Sobre el nafs comparado con un animal cf. también Nicholson (Poetas ..., p. 67 y A. Schimmel (Mystical ..., p. 112, The triumphal ..., p. 197; 70). San Juan de la Cruz también 


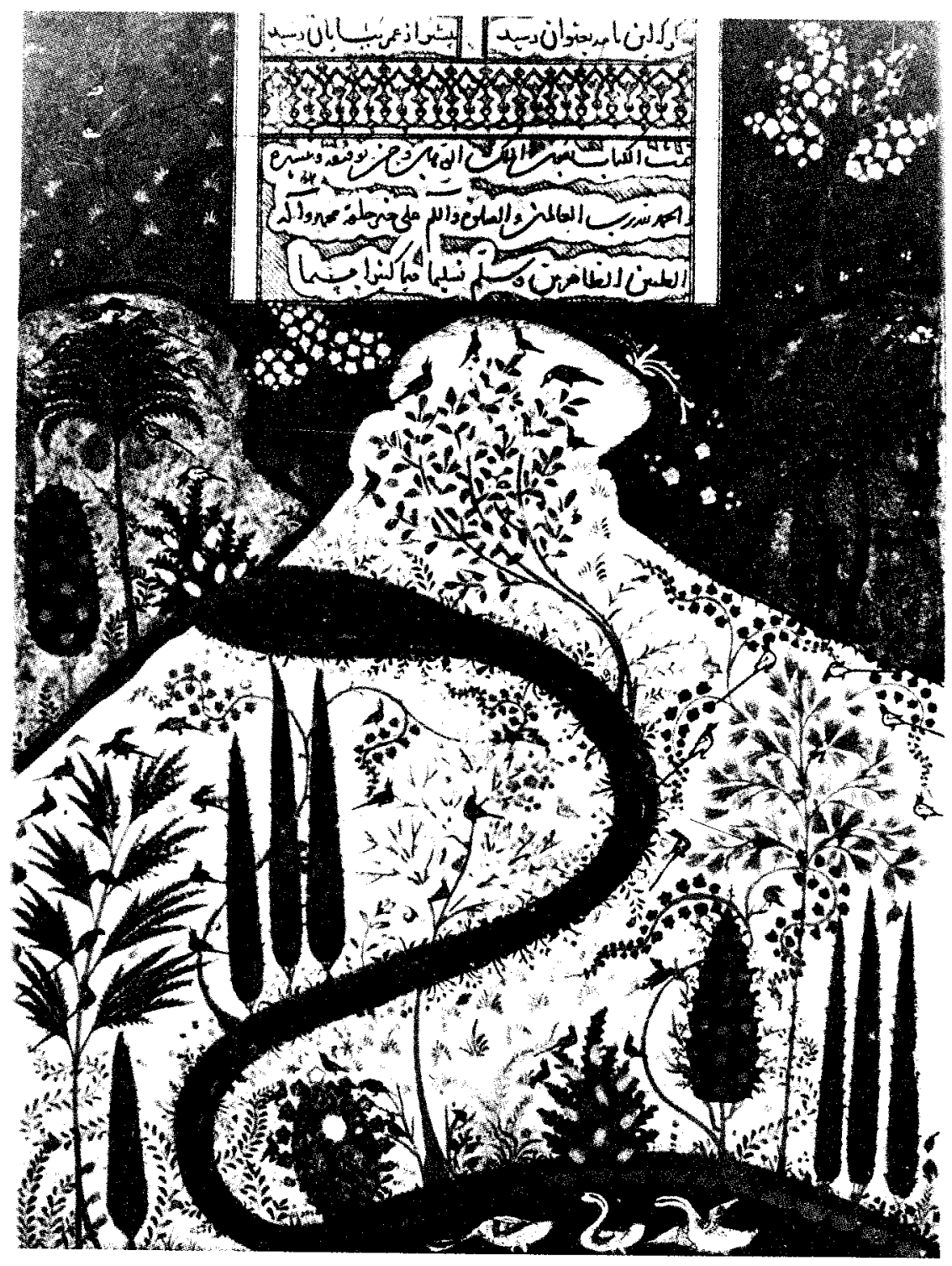

1. Momaña mística del Cäf. (Reproducida de una antología de poemas persas en manuscrito), Behbahan, Fars, Irán, siglo XIV 


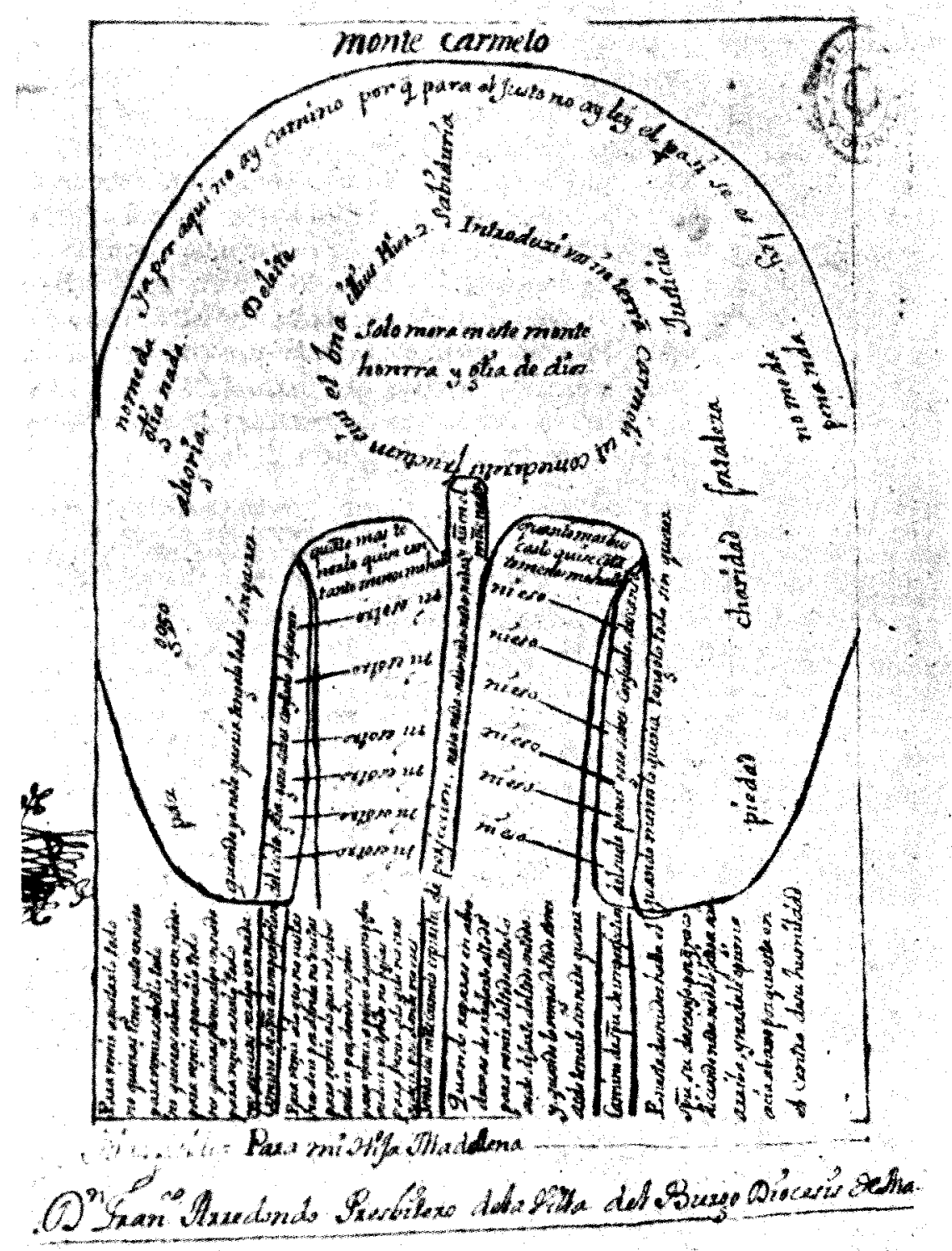

2. Carta autógrafa de San Juan de la Cruz del esquema original de la Subida del Monte (Ms. 6296, B. N.). 


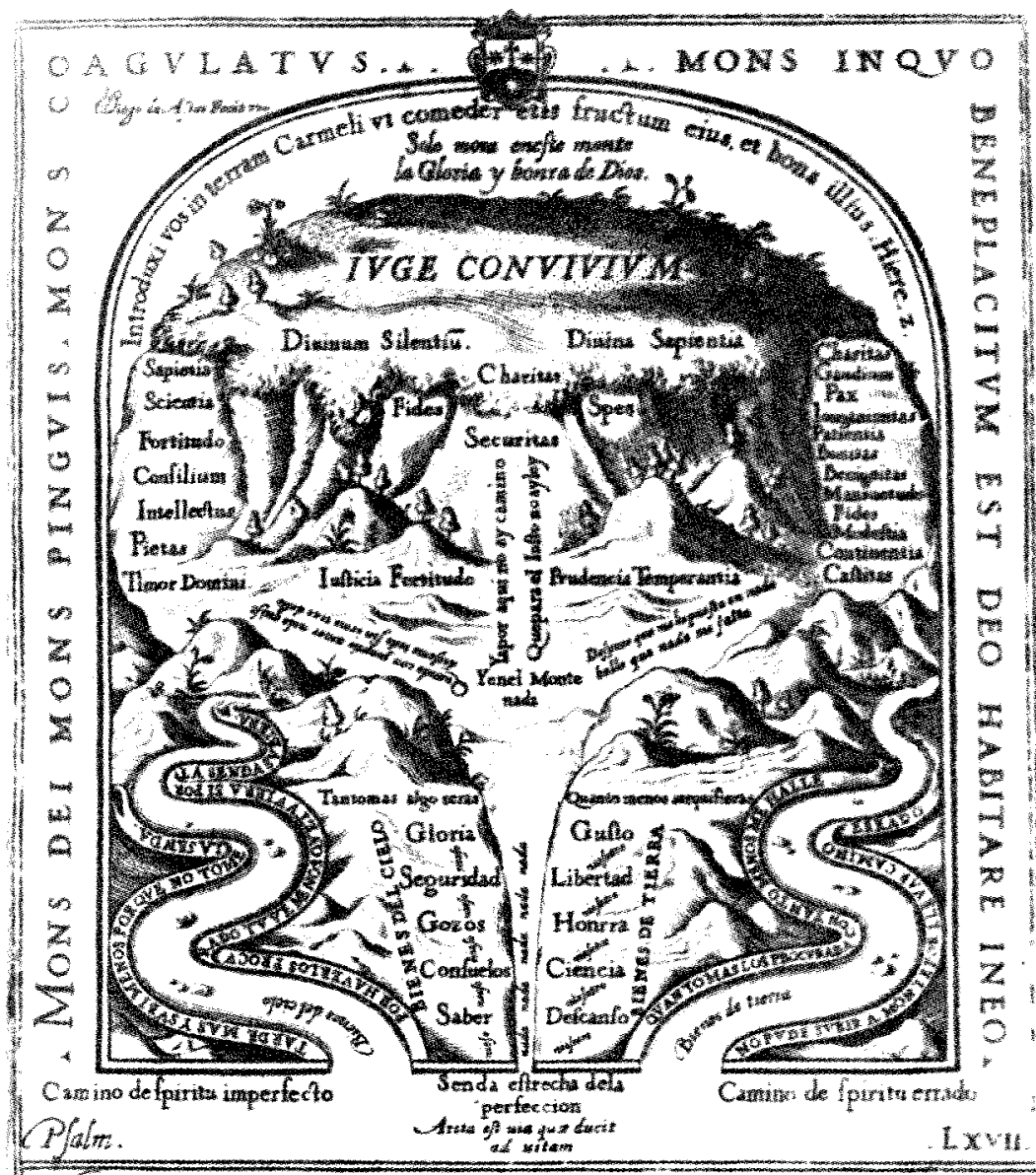

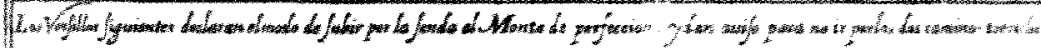

\begin{tabular}{|c|c|c|c|}
\hline 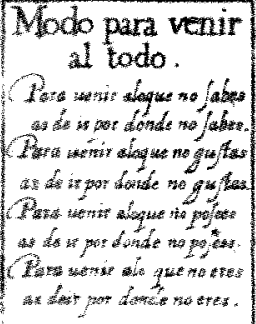 & 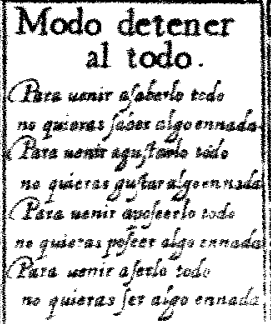 & 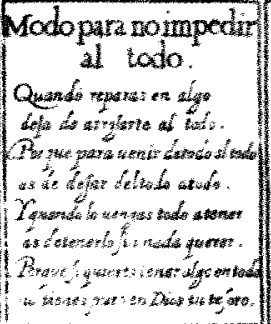 & 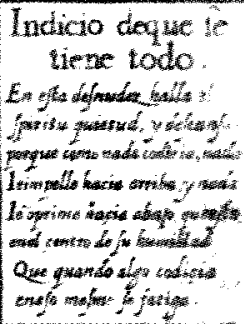 \\
\hline
\end{tabular}

3. Reelaboración del esquema sanjuanístico de la Subida del Monte (apud Obras espirituales que ecaminan un alma a la perfecta union con Dios. Por el Venerable P. F. Ivan de la Cruz, Barcelona, 1619). 


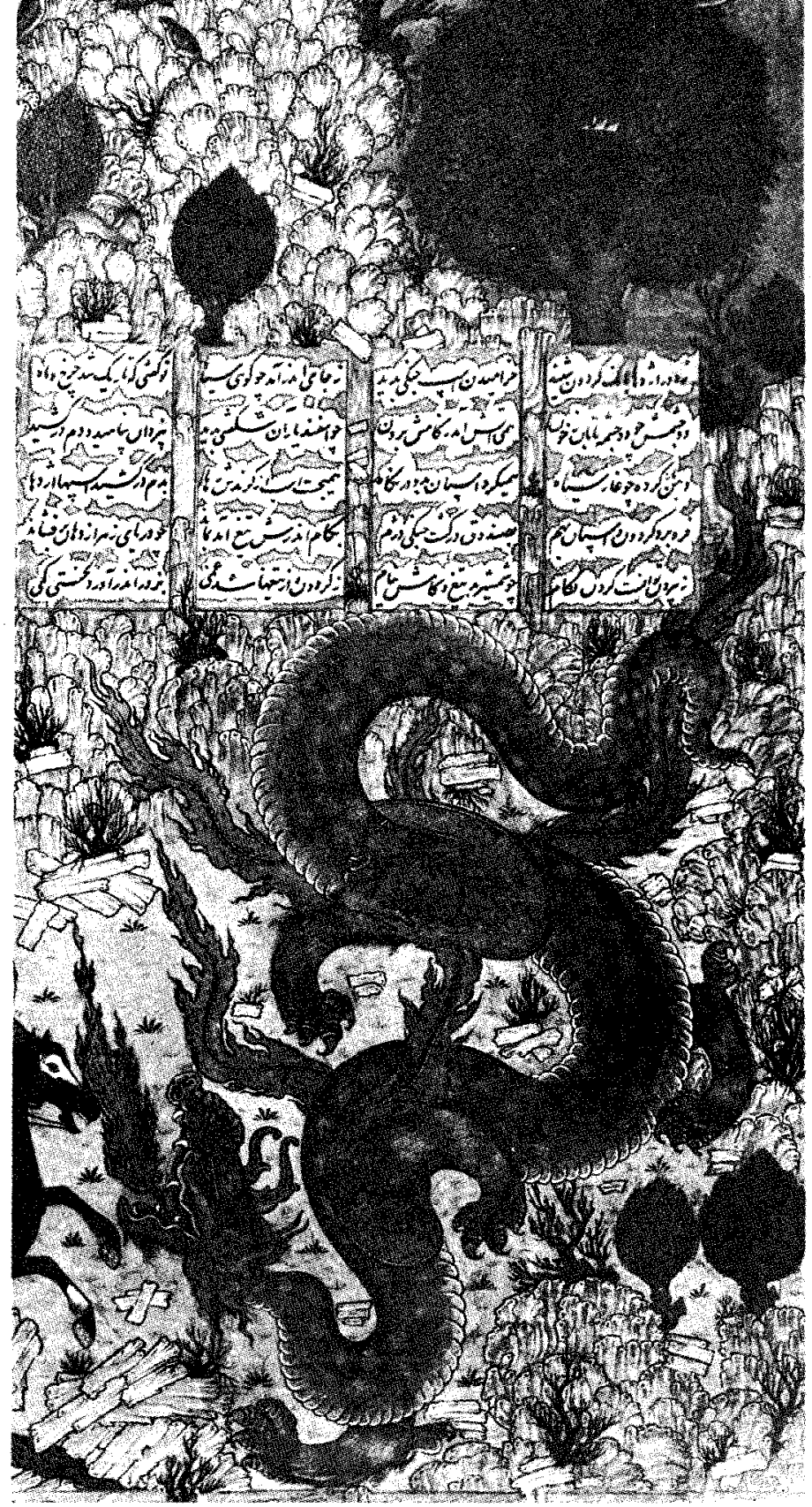

4. Esfandiyar matando al dragón místico. (Spencer Collection, Persian ms. 2, Firdawsi, Sah Nameh, 1614. Reproducido con autorización de Spencer Collection, The New York Public Library, Astor, Lenox and Tilden Fondations). 


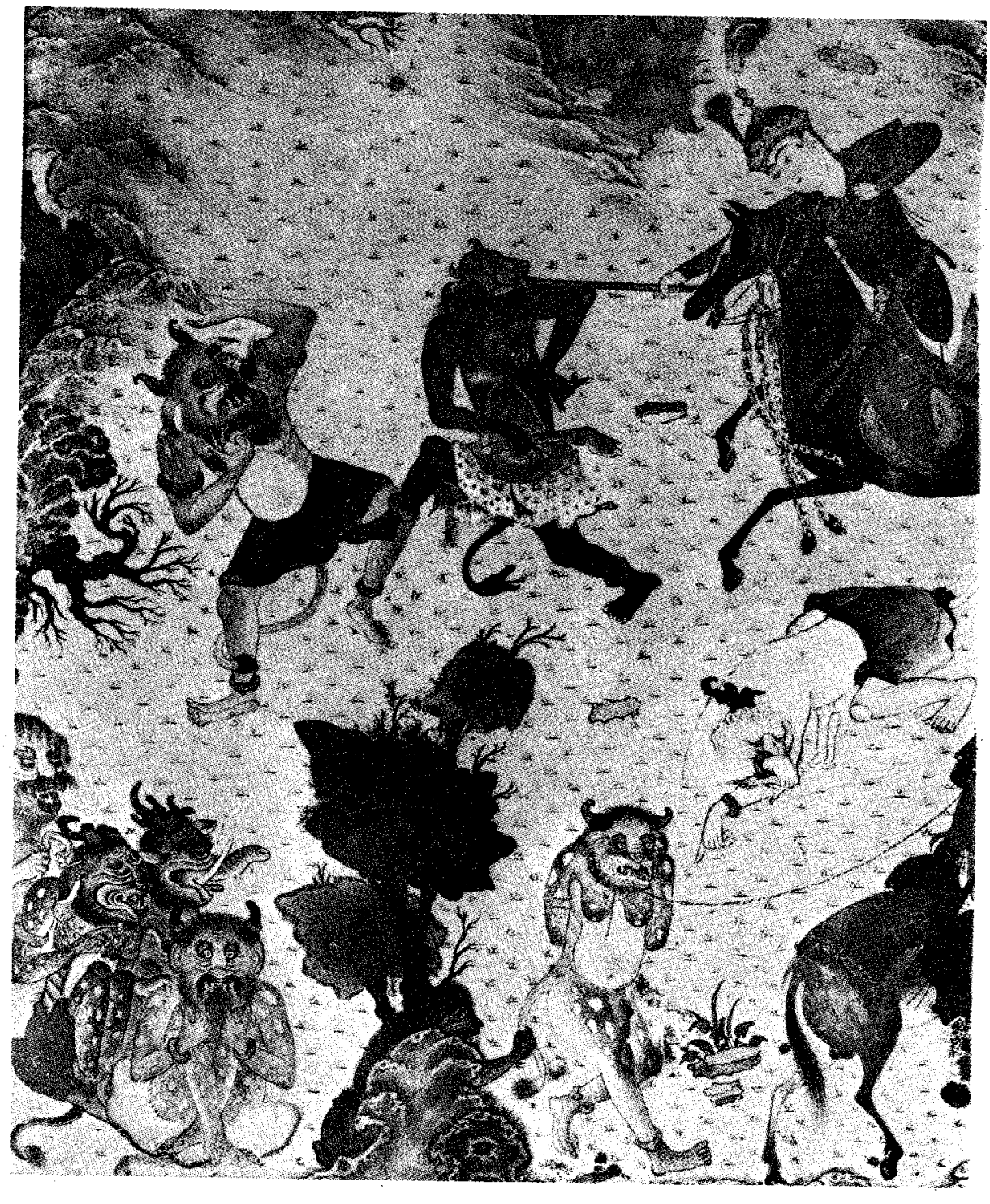

5. Tahmuras vence sobre los alyines o genios (en este caso, animalizados) que representan su sensualidad. (Detalle del ms. de San Nameh, Firdawsi, Irán. Reproducido con autorización del Museum of Art, New York). 


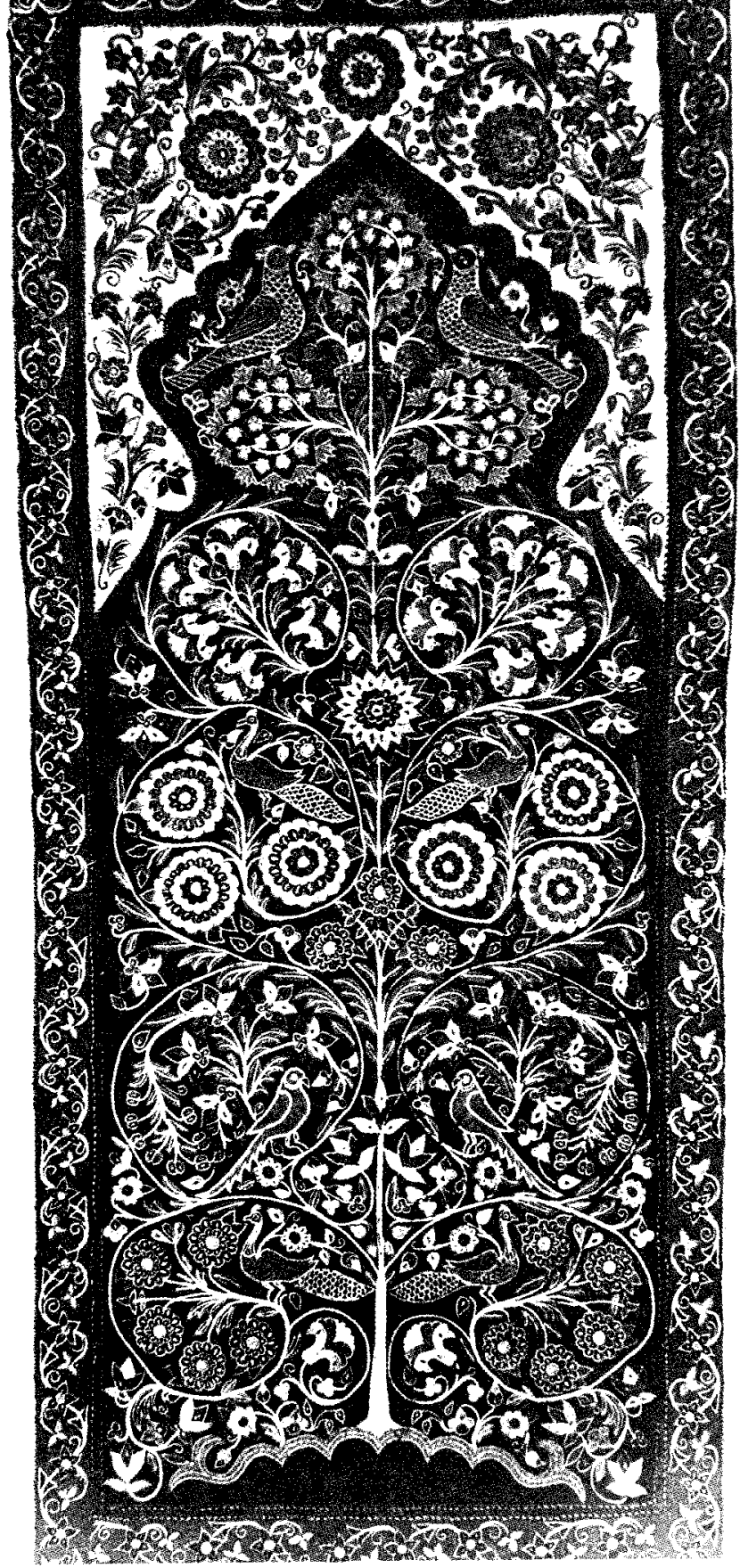

6. Árbol místico del alma. (Bordado de aplicación en franela, Isfaha, Irán, siglo XVIII). 
Acaso aun más curioso sea el símbolo del cabello, que "vuela en el cuello" de la Esposa del "Cántico" y que le sirve de "lazo" para atrapar al Amado.

Aquí San Juan, como apunta Francisco García Lorca ${ }^{71}$, parece imitar la versión de la Vulgata del Cantar de los cantares ("Vulnerasti cor meum in uno crine tui", 4:9) más que la traducción de fray Luis ("robaste mi corazón con uno de los tus ojos, y con sartal de tu cuello"). Sin embargo, fray Luis, al comentar otro pasaje del epitalamio ("Tu cabeza como el Carmelo: y los cabellos de tu cabeza como púrpura de Rey atada en canales", 7:5), advierte cómo el "rey" queda prendido en los cabellos de la Amada como en un lazo:

dice que (los cabellos) son un lazo, y como una cadena en que por su inestimable belleza, está preso el Rey, esto es, Salomón su Esposo (op. cit., p. 183).

La imagen del amante "atrapado" efectivamente por los rizos de la amada no es ajena a otras tradiciones que pudieron ser familiares a San Juan. Dámaso Alonso la documenta en la poesía popular y Emilio Orozco lo sorprende en el Idilio V. (v. 90) de Teócrito ("Un brillante cabello a lo largo del cuello ondea") ${ }^{72}$. El P. Crisógono y María Rosa Lida nos advierten que otros amadores laicos también emplean el motivo. Tienen razón: si espigamos en la Canción IV de Garcilaso encontraremos el tropo, si bien algo generalizado: "De los cabellos de oro fue tejida / la red que fabricó mi sentimiento... Pues soy por las cabellos arrastrado..." Petrarca ya lo tenía elaborado: "dico le chiome bionde, e'l crespo laccio, / che si soavemente lega e stringe / l'alma" (Soneto 197); "e folgorare [de ojos] i nodi [de los cabellos] ond' io son preso..." (Soneto 198). Pero es que ya los sufíes -y con siglos de anterioridad - habían vertido "a lo divino" el motivo poético del rizo o cabello que enamora y aprisiona y que europeos como Petrarca y Garcilaso sólo elaboran en un nivel profano. ¿Estará San Juan, una vez más, pisando terreno islámico y recibiendo la imagen ya elaborada por autores musulmanes, que parecen mucho más cercanos a él en este sentido que los renacentistas y los clásicos mencionados? El santo da muestras de conocer la equivalencia secreta del zulf o "rizo del cabello" (cf. Arberry, Sufism, p. 113), que es "gancho" con el que tantos sufíes como Ibn'Arabí y Sabastarí atrapan la Divinidad (o se dejan atrapar por ella):

If you ask me the long story / Of the Beloved's curl, / I cannot answer,

interpreta su sensualidad como ganado: "ya no guardo ganado". Aquí coincide con AlSarrâŷy, quien en su Kitäb al-Luma' compara al nafs con ganado u ovejas que el alma "pastorea".

"De fray Luis a San Juan: la escondida senda, Castalia, Madrid, 1972.

72 Poesia y mística, Guadarrama, Madrid, 1959, p. 203. 
for it contains a mystery / Which only true loves understand, / And they, maddened by its beauty, / Are held captive as by a golden chain ${ }^{73}$.

Los sufíes, con su característica imaginación verbal, transfiguran metafóricamente este rizo en el $L A M$ (la letra $L$ ) que tiene su misma forma:J.

Hemos ido explorando hasta el presente las coincidencias entre la simbología mística de San Juan de la Cruz y los sufíes: su abundancia y su precisión nos permiten considerar hoy lo seminales que fueron aquellos tempranos ensayos en los que Asín Palacios asoció al reformador a contextos literario-místicos islámicos. Estaba sentando las pautas para unas investigaciones que apenas comienzan y que darán una nueva perspectiva a la obra de San Juan, tan llena de prolongados misterios. Veamos ahora el caso de Santa Teresa de Jesús

\section{Santa Teresa de Jesús}

La reformadora de Ávila no parece ajena a la compleja imaginería espirutal de su "Senequita". Comparte en buena medida con su compañero de orden un lenguaje técnico y unos símbolos que parecerían también tener antecedentes islámicos. Detengámonos rápidamente en aquellos que ya hemos explorado en el caso de San Juan de la Cruz.

a) La "anchura" y "apretura"; el "vino"; la "fuente interior"; el alma como "huerto"...

La santa insiste una y otra vez en el vocabulario técnico coránico de la apretura ( tos de la apretura son inenarrables: “...porque son muchas las cosas que la combaten [al alma] con un apretamiento interior de manera tan sentible e intolerable, que yo no sé a qué se puede comparar sino a los que padecen en el infierno..."; “... es indecible porque son apretamientos y penas espirituales, que no se saben poner nombre""74. Curiosamente, la santa sí le sabe "poner nombre" a este intenso sufrimiento espiritual: lo denomina "apretamiento" - iqabd? a lo largo de todo el tratado de Las moradas. El paralelo con el qabd. y el bast de los sufíes es muy exacto: para Santa Teresa el estado alterno de este apretamiento es precisamente la anchura. La santa parecería interpretar desde la misma perspectiva de los teóricos del misticismo musulmán el salmo bíblico 118:32:

78 SA'D-UD-DIN MAHMUD SHABISTARI, The secret rose garden, trad. del persa, introd. de Florence Lederer, Lahore, 1969, p. 20.

${ }^{74}$ Moradas del castillo interior, VI, 2, Santa Teresa de Jesús, Obras completas, BAC, Madrid, 1976, pp. 406-407. En adelante abreviaremos: OC. 
..."Dilataste cor meum", dice que se ensanchó el corazón ... que ansí parece que como comienza a producir aquella agua celestial de este manantial que digo de lo profundo de nosotros, parece que se va dilatando y ensanchando todo nuestro interior y produciendo unos bienes que no se pueden decir, ni aun el alma sabe entender qué es lo que se da allí (Moradas, IV, 2, OC, p. 386).

En la obra de la reformadora abundan, de otra parte, los pasajes de celebración al vino del éxtasis y a la embriaguez espiritual que deja desatinada el alma. El versículo, "más valen tus pechos que el vino" se "descifra" de acuerdo a este sentido oculto que los musulmanes establecieron a lo largo de tantos siglos:

...cuando está en este gozo, tan embevecida y absorta, que no parece que está en sí, sino con una manera de borrachez divina, que no sabe lo que quiere, ni qué dice, ni qué pide ... Cuando despierta de aquel sueño y de aquella embriaguez celestial, queda como cosa espantada y embovada y con un santo desatino... (Meditaciones sobre los Cantares, IV, OC, p. 349).

Uno de los símbolos que más parece acercar a Santa Teresa a la tradición islámica es la del agua o la fuente interior. Asín Palacios comenzó a esbozar el paralelo en su póstumo "Śádilíes y alumbrados": para Santa Teresa la oración o meditación se da de dos maneras; una, trabajosa y difícil, otra, espon tánea y autónoma. La santa compara ambas maneras de oración con dos pilones que se hinchan de agua de modo diferente. El primero logra su ayuda por "muchos arcaduces y artificios, el otro está hecho en el mesmo nacimiento del agua y vase hinchendo sin nengún ruido; y si es el manantial caudaloso, como este de que hablamos, después de henchido este pilón procede un gran arroyo...siempre está procediendo agua de allí" (Moradas, IV , 3, OC, p. 386). Para Santa Teresa, los "arcaduces y artificios" son nuestras penosas diligencias (mortificaciones, meditación dirigida) por lograr la cercanía de Dios, mientras que el manantial autónomo es ya Dios mismo, cuyo conocimiento "brota" en nuestras almas sin esfuerzo especial por nuestra parte. Es exactamente el mismo símil que se repite entre los musulmanes (cf. supra, nota 59) y que también hemos visto en San Juan de la Cruz Veamos qué cerca de Santa Teresa está la metáfora de los šădilíes (Majafir, 39):

Lo mismo que comparan los místicos de esta escuela al alma con un espejo, así también la comparan con la fuente de agua y asemejan los conocimientos e intuiciones que en el alma existen con el agua que en la fuente hay, y dicen que a veces la fuente se oculta en la tierra, y sólo cavando se logra extraer de ella el agua. Y este símil que emplean asemejando al alma con la fuente es exacto, pues cuando el alma es alum- 
brada con las verdades místicas que le hacen olvidar sus cuidados y las cosas del mundo, brotan de ella los conocimientos divinos, lo mismo que el agua brota de la fuente; en cambio, a veces se necesita cabar en el agua con la azada del combate ascético y con la pala de la mortificación, hasta que brotan aquellas aguas, como antes brotaban espontáneamente o mejor todavía (Asín "Sādilieses", AlAn, 13, 1948, p. 270).

Esta alma henchida por aguas espirituales es también para la reformadora, al igual que para San Juan y para tantos seguidores del Profeta, un huerto oreado por brisas divinales, refrescado por la lluvia de la misericordia de Dios y adornado por las flores de las virtudes. Es preciso cuidarlo con diligencia, como buenos hortelanos.:

...con la ayuda de Dios hemos de procurar, como buenos hortelanos, que crezcan estas plantas [en el alma] y tener cuidado de regarlas para que no se pierdan, sino que vengan a echar flores que den de sí gran olor, para dar recreación a este Señor nuesto, y ansí se venga a deleitar muchas veces a esta huerta y a holgarse entre estas virtudes (Vida, 11 , OC, p. 59).

Ya hemos visto que los sufíes fueron buenos "hortelanos" de sus almas a lo largo de toda la Edad Media. Es interesante que Santa Teresa reconozca, pese a su mala memoria, que la imagen del huerto no es suya: "Paréceme ahora a mí que he leído u oído esta comparación, que como tengo mala memoria, ni sé adónde, ni qué propósito, mas para el mío ahora conténtame" (ibid).

Los paralelos entre Santa Teresa, San Juan y los espirituales del Islam se suceden: el alma es para la reformadora -como para ellos - un espejo que hay que bruñir (Moradas 7, II, 8) y cuyo centro u hondón último recibe la súbita iluminación de un relámpago o iluminación mística repentina (Moradas VI, IX, 3). Podríamos seguir acumulando ejemplos: el estudio comparativo entre la imaginería mística de Santa Teresa, San Juan y los musulmanes todavía está por hacer.

\section{b) El árbol místico}

Detengámonos ahora en otros símbolos que Santa Teresa comparte con los musulmanes pero que no hemos visto en San Juan de la Cruz. Uno de los más curiosos es el del árbol que crece en las aguas "vivas" del alma que es el alma misma:

...os quiero decir que consideréis qué será ver...este árbol de vida que está plantado en las mesmas aguas vivas de la vida, que es Dios...esta fuente de vida [la gracia de Dios] adonde el alma está como un árbol plantado en ella, que la frescura y fruto no tuviera si no le procediere de allí, que esto le sustenta y hace no secarse y que dé buen fruto... (Moradas, I, 2, OC, pp. 367-368). 
El símbolo del árbol cósmico lo comparten las culturas más diversas. El Bhagavad-Gïtā y las Upanišads, por ejemplo, nos presentan al universo en la forma de un árbol que extiende sus ramas por toda la tierra. La mitología escandinava y gérmanica repiten la idea, aunque Mircea Eliade cree que la imagen tiene un origen oriental: "[el árbol cósmico] a une valeur toute particulière dans les croyances des peuples nordiques et central-asiatiques mais il est probable que l'origine est orientale (mésopotamienne)" (op. cit., p. 255). Algunas de estas tradiciones asocian, como la reformadora, al árbol con el agua. En el Apocalipsis 22:2 se nos habla del árbol de vida que da doce frutos y que crece junto al río que fluye del trono de Dios en la Jerusalén Celestial ${ }^{75}$, y la idea no está lejos de numerosas tradiciones indias, persas y árabes ${ }^{76}$.

Los alquimistas, sin embargo, interpretan el árbol cósmico en términos de sus propias experiencias espirituales y se convierte para ellos en "the outward and visible sign of the realization of the self", según Carl Jung (op. cit.,196). El alquimista árabe Abu'l Qasim al Iraqi (siglo XIII) entiende el árbol simbólico de su alma que brota de una fuente precisamente en esos términos. Ya con esto nos vamos acercando a Santa Teresa, que advierte cómo el árbol (que representa a su alma y no al universo) crecerá bien o mal dependiendo del tipo de aguas espirituales que lo alimenten: las limpias de la gracia o las pútridas del pecado. Los paralelos se multiplican cuando acudimos a la literatura mística de los sufíes. Entre ellos se repite una y otra vez la imagen del árbol del alma que brota de la fuente espiritual precisamente en los mismos términos en que la empleará Santa Teresa. En otras palabras: los místicos y los alquimistas musulmanes dan al árbol - simbolo del universo para tantas culturas - una nueva dimensión de interioridad mística. Veamos más de cerca las disquisiciones de los teóricos del Islam.

El antiguo Book of certainty entiende que el árbol y la fuente del jardín del Edén tienen su contrapartida en el alma:

In the centre of the Garden of Eden there is said to be not only a fountain but also a tree, at whose foot the fountain flows. This is the Tree of Immortality, and it is an outward image of the inward Tree of Immortality, which grows in the Garden of the Heart (op. cit., o. 40).

El persa Šabistarí celebra también ese árbol que crece, como el de Santa Teresa, en el hondón de su espíritu y que es el espíritu mismo: "From water and earth springs up «the soul's kernel» into a tree,

75 También en Ezequiel 47 encontramos la asociación, aunque más vaga, del árbol con la fuente o río alegórico.

${ }^{76}$ En el capítulo 48 del Mi răây de Mahoma, Gabriel y Ridwān llevan a Mahoma a un lugar espacioso llamado al-Sidra al-muntahā. Allí encuentran un árbol inmenso, hecho de perla, a cuyo pie "nacía una fuente de agua clara sobre toda ponderación" que era la gracia perfecta (apud MUÑOZ SEODINO, op. cit., p. 220). 
Whose high branches are lifted up to heaven" (op. cit., p. 32). El citado Nūri de Bagdad nos habla repetidas veces del mismo símil, que explora en detalle en varios capítulos de su Maqāmät al-qulüb. Traducimos del árabe un breve fragmento del capítulo I:

Dios plantó [en el alma] el árbol del conocimiento místico ... su raíz está en el corazón del místico y sus ramas llegan al cielo, debajo del trono de Dios ... Luego puso [Dios] un río de agua de mar quieta que alimenta a aquella planta ... (op. cit., pp. 131-132).

El místico bagdadí advierte, en estrecho paralelo con la reformadora, que el árbol del conocimiento espiritual del alma crece de acuerdo a nuestra formación espiritual positiva o negativa (cf. al respecto sus capítulo XVII, "Semblanza del árbol del conocimiento en el corazón del místico", y XIV, “Semblanza del árbol del deseo”). La tradición islámica del símil del árbol del alma es muy intensa: IbncArabi, entre tantos otros, considera el árbol cósmico en su doble dimensión: macrocósmica y microcósmica. Dice Laleh Bakhtiar:

The Cosmic Tree, Tuba, in its macrocosmic form grows at the uppermost limits of the universe. In its microcosmic form, its cultivation depends on the mystic. In its macrocosmic aspect, it is associated with the Cosmic Mountain on Top of which the Cosmic Tree grows... in the microcosmic form ... it is the symbol of wisdom which, through roots in meditation, bears fruit of the Spirit (op, cit., p. 57).

El símbolo fue tan común entre los musulmanes que encuentran expresión en las artes plásticas persas, como en este bordado de aplicación en franela que reproducimos (figura 6). De alguna manera, la antigua imagen musulmana parecería haber encontrado su camino hasta la reformadora de Ávila en pleno siglo XVI español.

\section{c) El gusano de seda}

Otro símbolo espiritual que se asocia inmediatamente a Santa Teresa es el del gusano de seda. El alma es a manera de gusano de seda que teje su propia morada de unión con Dios y que al hacerlo se aleja de todo lo criado:

... crecido este gusano ... comienza a labrar la seda y edificar la casa adonde ha de morir ... Pues aquí veis, hijas, lo que podemos con el favor de dios hacer: que Su Majestad mesmo sea nuestra morada como lo es en esta oración de unión, labrándola nosotras. ... Pues, ;ea, hijas mías!, priesa a hacer esta labor y tejer este capuchillo, quitando nuestro amor propio y nuestra voluntad, el estar asidas a ninguna cosa de la tierra ... (Moradas, V, 2, OC, pp. 395-396).

El símil parece, una vez más, tener un origen oriental. Varios críticos - Gaston Etchegoyen, González Palencia, entre otros- 
admiten que fueron los árabes quienes aclimataron el gusano de seda en Andalucía. Pero hay más: el gusano de seda se utiliza como símbolo místico en el Islam precisamente en el mismo sentido de Santa Teresa. ¿Habrá tenido la reformadora acceso indirecto a estas fuentes literarias donde el símbolo queda consagrado, ya que admite no haber sido nunca testigo ocular de la cría de la seda?77 Sea como fuere, el persa Rumi -en pleno siglo XIII- es uno de los más celebres plasmadores del símil. Citemos, entre tantísimos ejemplos que ofrece el poeta, estos versos en los que celebra cómo las hojas que come el gusano se transmutan en seda y los aislan, exactamente igual que en el caso de Santa Teresa, de todo lo criado: "When the worm eats leaves the leaf becomes silk/we are the worms of love, for we are without the/leaves (provision of sorrows, barg) of this world". (Divan-e-kabir 1484/15652, apud Schimmel, The Triumphal ..., p. 111).

No sólo el gusano de seda sino su producto, la seda misma, obsesiona a Rumi, que la explota largamente como símbolo místico. Acaso estén en Oriente los gérmenes de esta imagen espiritual que Santa Teresa supo hacer tan familiar en Europa.

\section{d) Los siete castillos concéntricos del alma}

Cerremos nuestro estudio con uno de los símbolos más famosos de la mística peninsular: el de los siete castillos concéntricos del alma de Santa Teresa de Jesús. Si existe una imagen célebre por su hermosa plasticidad y por su asombrosa "originalidad" es este.

La santa, que tan mal solía recordar sus fuentes, declara - sin duda con toda inocencia- que el delicado esquema místico es de su propia minerva, inspirada divinalmente:

Estando hoy suplicando a nuestro Señor hablase por mí - porque yo no atinava cosa que decir ni cómo comenzar a cumplir esta obediencia [la de escribir el libro de Las Moradas del castillo interior] con algún fundamento, que es considerar a nuestra alma como un castillo todo de diamante o muy claro cristal, adonde hay muchos aposentos, ansí como en el cielo hay muchas moradas ${ }^{78}$.

77 "Ya havréis oído sus maravillas en cómo se cría la seda, que sólo Êl pudo hacer semejante invención, y cómo de una simiente que es a manera de granos de pimienta pequeños (que yo nunca la he visto, sino oído, y ansi, si algo fuere torcido, no es mía la culpa)..." (ibid).

${ }^{78}$ Moradas del castillo interior, I, OC, p. 365. El P. Diego de Yepes insistirá en que el símbolo es producto de una inspiración directa de Dios a la reformadora, y cita el testimonio. personal de ella en torno a la génesis de su famoso tratado místico. Aunque Robert Ricart ("Le symbolisme du *Château .. Iterieur» chez Sante Thèrese", $B H i, 67,1965,25-41$ ) y Víctor G. de la Concha (El arte literario de Santa Teresa, Barcelona, 1978) cuestionan la absoluta legitimidad de este testimonio, nos parece útil consignarlo porque parecería confirmar que se le dio completo crédito a la idea de que el símil era original de Santa Teresa. He aquí las palabras de P. Diego: "Habia deseado esta Santa Madre ver la hermosura de un alma que está en gracia... Estando en este deseo le mandaron escribir un tratado de oración, lo cual tenía ella muy bien 
No sería muy difícil dar la razón a la santa. La imagen es de una extraña hermosura y de una innegable complejidad imaginativa. El alma se le muestra a manera de siete castillos o globos concéntricos de fino cristal o diamante. En el último está Dios, con quien el alma se une, dejando atrás al demonio que, en la forma de distintos animales ponzoñosos, quiere penetrar en los castillos que marcan las moradas progresivas del camino místico. El esquema simbólico parecería original por una importante consideración adicional: ha resultado muy difícil documentarlo, en todos sus pormenores y elementos constitutivos, en la mística europea que antecede a la reformadora.

El símbolo teresiano ha dado pie, en efecto, a uno de los problemas de filiación más interesantes de la literatura española. Haciendo un respetuoso caso omiso a la pretendida originalidad de Santa Teresa, los estudiosos se han lanzado a la búsqueda de las fuentes lietrarias de los siete castillos concéntricos del alma. Los hallazgos de críticos como Morel Fatio, Gaston Etchegoyen, Menéndez Pidal y $\mathbb{R}$. Hoornaert atenuan en algo nuestra sorpresa frente al símil ya que documentan la equivalencia del alma como castillo en autores espirituales anteriores a la santa. (Nos parece justo advertir también que Carl Jung ${ }^{79}$ y Mircea Eliade ${ }^{80}$ se ocupan de subrayar la universalidad de la imagen). Los antecedentes, con todo, resultan bastante lejanos y decepcionantes: en ninguno encontramos el avance místi-

sabido por experiencia. Víspera de la Santísima Trinidad, pensando qué motivo tomaría para este tratado, Dios que dispone las cosas en sus oportunidades, cumplióle este deseo y dióle el motivo para el libro. Mostróle un globo hermosísimo de cristal, a manera de castillo, con siete moradas y en la séptima, que estaba en el centro, al Rey de la Gloria con grandísimo resplandor que ilustraba y hermoseaba aquellas moradas hasta la cerca, y tanta más luz participaban cuanto más se acercaban al centro. No pasaba esta luz de la cerca, y fuera de ella todo era tinieblas y inmundicias, sapos y víboras y otros animales ponzoñosos... Esta visión me dijo aquel día.... Tomó de aquellas siete moradas del castillo, grados de oración, por los cuales entramos en nosotros mismos y nos vamos allegando a Dios. De manera que cuando llegamos al hondo de nuestra alma y perfecto conocimiento de nosotros mismos, entonces llegamos al centro del castillo y Séptima morada donde está Dios y nos unimos cen Él por unión perfecta (apud Miguel Asín Palacios, "El símil de los castillos... pp. 268-269). Este estudio de los castillos sirvió de base a nuestra ponencia "De Nūrī de Bagdad a Santa Teresa de Jesús: el símbolo de los siete castillos concéntricos del alma", leída en el VIII Congreso Internacional de Hispanistas, Venecia, agosto de 1980.

${ }_{79}$ En sus Alchemical studies, op. cit., Jung reproduce el grabado de un castillo for tificado con dieciséis torres y un foso interior. El esquema coincide perfectamente con los mandalas orientales que describen el $T a o$ o la búsqueda de la conciencia profunda, pero fue dibujado por uno de sus pacientes (cf. grabado A-10, p. 60).

${ }^{80} \mathrm{La}$ intuición fundamental teresiana es muy honda en el sentido de que parece corresponder a una concepción universal del "espacio sagrado" que se aplica a la construcción de templos o palacios de sentido espiritual. Eliade nos describe la configuración arquitectónica de los mandalas: "La même portée cosmogonique se vérifie dans la construcción du mandala telle que la pratiquent les écoles tantriques. Le mot signifie "cercle"; les traduction tibétanies le rendent tantot par "centre", tantôt par "ce qui entoure". Quant à la chose, elle consiste en une serie de cercles, concentriques ou non, inscrits dans un carré... L' initiation consiste essentielment pour le néophyte a pénétrer dans les differents zones ou niveaux du mandala. 
co claramente estructurado a lo largo de siete moradas (o castillos) cada vez más interiores. Etchegoyen, que es uno de los que más a fondo ha estudiado el problema filogenético de los castillos en su L'amour divin. Essai sur les sources de Sainte Thérese (1923) propone como fuentes principales de Teresa a Bernardino de Laredo y a Francisco de Osuna. Ambos autores, tan leídos por Santa Teresa, conciben el alma interior como castillo pero sus bosquejos no bastan para explicarnos los pormenores del símbolo de la reformadora. Osuna se limita a un esquema demasiado apegado a las alegorías medievales, en el cual los enemigos tradicionales (carne, mundo y demonio) intentan penetrar al castillo del alma ${ }^{81}$. El símil de Laredo es más intrigante y complejo pero en el fondo más distante del teresiano: el entendimiento es a modo de "civitas santas" asentada en un campo cuadrado, de fundamento de cristal y de muros de piedras preciosas, con un cirio pascual en el centro que simboliza a Cristo ${ }^{82}$. Estos son los esbozos metafóricos que la crítica en general ha considerado mejor ayudan a explicar el símil de Santa Teresa, pero es obvio que bastante poco tienen que ver con sus

Le rite peut être tenu, a titre égal pour une equivalence du pradakshina, le cérémonial bien connu du tour d'un temple ou d'un monument sacré, (stûpa), ou de l'initiation par l'entrée rituelle dans une labyrinthe. L'assimilation du temple au mandala est évidentte dans le cas de Borrobudur..." (op. cit., pp. 314-315). Parecería que estamos aun más cerca de Santa Teresa con los zigurats babilónicos de oculto sentido místico: "Les celebres ziqqû́râts de Babyloine typificent la montagne cosmique aux sept étages, aux coleurs respectives des sept Ceiux; par elles était possible, rituellement, l'ascencion jusq'ua sommet, c'est-a dire jusqu'au point culminant qui est le nord cosmique..." (HENRY CORBIN, L'homme de lumiere ..., p. 66). Pero en este caso Corbin advierte que las subdivisiones del camino mistico en siete grados que corresponden a los siete cielos constituye un simbolo típicamente oriental que habrá de tener elaboraciones posteriores en la literatura espiritual islámica. Será interesante tomar esto en cuenta ante los esquemas místicos de los siete castillos concéntricos del al ma de los musul manes Nürï de Bagdad (siglo IX) y el anónimo autor de los Nawädir (siglo XVI), en los que nos detendremos más adelante.

${ }^{81}$ Dice Osuna: "[que se guarde] el corazón con toda diligencia, como se guarda el castillo que está cercado, poniendo contra los tres cercadores tres lámparas: contra la carne, que nos cerca con deleites, poner la castidad; contra el demonio, que nos persigue con rencores y envidia, poner la caridad..." Hay tres puertas del castillo por donde puede entrar el demonio: por una entra el engaño, por otra el temor, por otra el hambre. "Y es de notar que, si el demonio solamente halla la una parte o camino de estos tres mal guardado, por allí se entra al castillo del corazón..." (Tercer abecedario espiritual, BAC, Madrid, 1971, pp. 198 y 202).

82 El extraño esquema de Laredo se aleja notablemente del de Santa Teresa: ["El entendimiento es un campo...] de cuadrada igualdad y procure de cercarle todo de un finocristal, que es piedra clara y preciosa. Y en cada uno de los paños o piezas de aquel cuadrado se han de levantar tres torres labradas en preciosa pedrería, digo de gemmas preciosas: así que aquesta cerca torreada haga cercada ciudada, y que sea civitas santa, Jerusalén celestial, cuyos muros está escrito que son piedras preciosas [A poc. 21, 18]... De lo alto de estas torres han de pender cuatro escudos de fino oro... En el medio de este ya cercado campo ${ }_{2} . .$. que se considere estar encendido un rico cirio pascual, cuya cera es limpísima, cuyo pabilo es purísimo, .... obrado en tal perfición..., que ansí está el cirio encendido, que en algún espacio o tiempo es imposible acabarse, o disminuirse, o faltar su claridad..., Ya que está encendido el cirio, la cera es el sacratísimo cuerpo de Cristo; el pabilo, su ánima felicísima; y de su lumbre perfectamente 
imaginativos siete castillos concéntricos. Incluso es importante señalar en este sentido que esquemas del castillo espiritual como los mencionados de Osuna y Laredo (o de Ludolfo de Sajonia [el Cartujano], o de Raimundo Lulio) son mucho más abundantes en la literatura medieval y renacentista de lo que los estudiosos han documentado hasta la fecha.

Ya San Bernardo desde el siglo XIII compara una y otra vez al alma con una fortelza asediada por enemigos espirituales ${ }^{83}$. Gerson no se queda atrás y se queja de los asaltos del mundo, la carne y el demonio al castillo de su conciencia interior ${ }^{84}$. Por caminos seme-

encendida podéis... alzar el entendimiento a la santa Trinidad en una sola y purísima substancia... Y en esta santa ciudad nunca es necesario sol ni luna, ... porque la claridad de Dios la esclarece... Es el muro cristalino la clara virginidad que esclarece la ciudad; las diversas gemmas... son la grande diversidad de los bienaventurados; doce torres, doce apóstoles, cuatro escudos son los cuatro evangelistas... Repasa la claridad y resplandor reverberante en las gemmas,.... y lo demás, porque así se comunican los bienes de nuestro Dios en los bienaventurados... Y aun tenemos otra torre que es castillo, es fortaleza, casa fuerte, casa real, es aposento del rey, alcázar de la ciudad, está más cerca que del cirio, es homenaje de Dios y excede a las otras torres en tan cumplida eminencia, que este entendimiento ilaco no puede cuánto alcanzar... es tundada sobre un muy tino cristal tan tuerte como diamante, que no se puede quebrar, y de mil piedras preciosas está cercado su muro y de zafiro y esmagerado son sus puertas fabricadas (Tob. 13, 21)... este nuestro alcázar real, es consagrado en Iglesia,... es templo de Dios ... Hierusalem ... ciudad de Dios ... nuestra claridad es Dios, es Cristo Jesús bendito, es aouel cirio pascual ... resplandor y claridad de su lumbre, la inmensa divinidad..." (Subida del Monte Sión, místicos franciscanos españoles, BAC, Madrid, t. 2, 1948, pp. 270-274).

83 En su sermón "De la guarda constante del corazón" (Sermones varios, núm. 82, Obras completas, BAC, 1953, 1955, p. i 107) dice: "Guarda con toda diligencia tu corazón, ... [PI. 183, 699] porque de él procede la vida eterna... debemos cultivar y custodiar preferentemente el castillo del alma, porque de él procede la vida eterna. Mas este castillo, colocado en la tierra de los enemigos, se ve atacado por todas partes; por eso le debemos proteger con vigilante solicitud... por todas partes: por abajo y por arriba, por delante y por detrás, por la derecha y por la izquierda. Por abajo le acomete la concupiscencia de la carne, que lucha contra el alma... Por arriba está inminente el juicio de Dios... Por detrás está la delectación mortífera, que nace del recuerdo de los pecados pasados; por dehante, la insistencia de las tentaciones; por la izquierda, la inquietud de los hermanos arrogantes y murmuradores; por la derecha, la devoción de los hermanos obedientes". En sus Sermones de santos (Sermón 2: En la ascención de la Virgen María, titulado Sobre el modo de limpiar, adornar y amueblar la casa) San Bernardo comenta el versículo: "Entró Jesús en un castillo y una mujer llamada Marta le recibió en su casa" $[\mathrm{Pl} .183,417]$. San Bernardo va alternando los sentidos de este castillo: el mundo, la encarnación de Jesús, el seno de María, la casa o castillo de nuestra alma. Cita también para sus alegóricos el Prov. 4,23: "Con toda diligencia guarda tu corazón, porque de él procede la vida". El enemigo (se sobreentiende el demonio) puede vencer sobre "el muro de la continencia... [y] el antemural de la paciencia" del castillo alegórico del aln. . p. 707). Pero Jesús "entró en el castillo, y atacando al fuerte saqueó sus despojos... quebrantó las puertas de bronce e hizo pedazos los cerrojos de hierro, sacando al prisionezo de la cárcel y de la sombra de la muerte. Esta su salida fue por la puerta de la confesión..." (p. 708).

84 “...l'ostel de mon âme, est durament assegié: de toute (s) partes on lui fait crueux assaulz et tres perilleuse guerre... par le monde, par la chier, par l'ennemi. C'est l'otel qui est a vous 
jantes van otros teóricos como Hugo de San Víctor (De arca Noe morali) y la anónima autora inglesa del Ancren Riwle (The nun's rule) del sigloXIII. En una variante curiosa, Robert Grosseteste ${ }^{85}$, en su Chateau d'amour anglo-francés del siglo XIII equivale el castillo alegórico al vientre de la Virgen María, que recibe a Cristo. Se sirve, como muchos otros espirituales, de un pasaje bíblico que a Santa Teresa no se le ocurrió utilizar: "Intravit Jesus in quodam castellum. . ." (Lucas 10:30). Meister Eckhart respalda sus castillos metafóricos del vientre de la Virgen con el mismo pasaje de San Lucas y traduce el castellum bíblico por "bürgelin" — pequeño burgo o aldea más bien que propiamente castillo ${ }^{86}$.

Los portugueses - San Antonio da Lisboa (o de Padua), frei Paio da Coimbra, el autor del Boosco deleitoso- se obsesionan con el símbolo del castillo del alma aunque siempre lo desarrollan con las mismas limitaciones de sus correligionarios europeos. El tratadista más interesante entre ellos acaso sea Dom Duarte, que en su Leal conselheiro nos habla de las cinco "casas de nosso caracom" cada vez más interiores. El último aposento o casa es el "oratorio" 87

par droit car vous l'avez fait et fondé par creation, et jadiz l'aornastes par grace on saint baptesme" (Sermon pour la Pentecôte: Mansionem) (De la première chamberiere, Oroison, apud Six sermons francais inédits de Jean Gerson, Paris, 1946, p. 74).

${ }^{85}$ En beau lu fut il veraiment, $/ \mathrm{La}$ ou Deu de le ciel descent./En un chastel bel et grant, /Bien fermé e anenant, /Kar c'est le chastel de ammur./De tuz solaz, de tuz sucur. $/ .$. Ou habiter/ ne poet nul mal./Environ ad quatre tureles./En tut le mund ni ad si beles. $/ .$. Le castel est bel e bon,/Dehors depeint environ./De treis colurs diversement./ $\mathrm{E}$ si est vert le fundement, $/ \mathrm{Ki}$ a la roche se joint. /...La colur ki est en mi liu. / Si est inde e si est bliu, /...La trerce colur par en som/...Plus est vermeille ken'est rose/ ...En mi la tur plus hautaine./Est surdant une fotaine./Dont issent quatre ruissel/... Santé porreit recoverer/K'a cel ewe peiist puiser $/ .$. En cele bele tur el bone $/ \mathrm{I}$ ad de ivoire une trone, $/ \ldots$ Ce est le chastel de delit $/$ Cum la duce Virgine Marie/... La roche k'est si bien polie,/C'est le cuer la duce Marie,/Ki onkes en mal ne mollist /...Et de si tres bele verdur/Ce est la fei de la virgine/... C'est cele ki tant est vermeille/...E c'est la seinte charité/...Les quatre tureles en haut/... Sunt quatre vertuz kardinals. /...La baille k'est en mi fermé/Signifie sa chasteté. (Le Château d'Amour, Paris, 1918, pp. 105-106 y 111).

86 Cf. Selected treatises and sermons translated from Latin and German, London, 1958.

87 Veamos la pormenorización de Dom Duarte: “...en conssiro no coracom de cadahuũ de nos cynquo casas, assy ordenadas como costuman senhores. Prymeira, salla, em que entram todollos do seu senhorio que omyxyados nom som, e assy os estrageiros que a ella querem viir. Segunda, camara de paramento, ou ante-camara, em que costuman estar seus moradores e alguũs outros notavees do reyno. Terceira, camara de dormyr, que os mayores e mais chegados de casa devem aver entrada. Quarta, trescamara, onde sse custuman vestir, que pera mais speciaaes pessoas pera ello pertecentes se devem apropriar. Quinta, oratorio, em que os senhores soos algũas vezes cadadia he bem de sse apartarem pera rezar, leer por boos livros e penssar em virtuosos cuidados. $\mathrm{E}$ avemos em cadahua destas casas aquellas doze paixoöes que ja screvy, scilicet Amor, Desejo, Deleitaçom, Odio, Avorrecymento, Triste[za], manssidðoe, Speranca e Atrevymento, Sanha, Desperaçom e Temor... E pois a fim delies he seu començo, prymeiro a devemos or denar em nosso coraçom, poendo na salla todallas cousas que nom tem outra, afora filhar prazer. Na camara do paramento as do proveito. As da saude corporal na camara do dormir. Nas trescamaras, os feitos da honra... O estudo specialmente seja guardado pera o servicio de nosso senhor e seguymento das virtudes" (capítulo LXXXI, "Das casas de 
y lleva razón Mario Martins ${ }^{88}$ cuando cree ver relación de parentesco entre el portugués y Santa Teresa. En España cabe añadir entre los que atribuyen el castillo interior a Juan de los Ángeles y a Diego de Estella. En Italia, Dante parecería acercarse a la reformadora con su "nobile castello / sette volve cerchiato d'altre mura" (Inf. IV, 106) pero su castillo no simboliza el alma sino la entrada al jardín del Limbo.

Las alegorías del castillo de los espirituales europeos son, como vemos, muy extendidas, pero comparan desfavorablemente con el detallado símil teresiano ${ }^{89}$. Más decepcionantes y remotas resultan otras fuentes que se han mencionado en relación al famoso símbolo, como las de los castillos de los libros de caballerías, la de los castillos alegóricos del amor cortés de la poesía cancioneril del siglo $\mathrm{XV}$, las "mansiones" de San Agustín y aun algunos pasajes bíblicos sólo vagamente relacionados con el símil ${ }^{90}$. Nos parece, de otra parte, casi un acto de desesperación crítica el de algunos estudiosos que optan por una solución extra-literaria que explique la súbita inspiración de la santa. Miguel de Unamuno formula hacia 1909 la hipótesis de que la ciudad murada de Ávila fue la que sirvió de modelo a las moradas, y Robert Ricart, en 1965, al final de un artículo (cit. supra, nota 78), que prometería más por su penetrante rigor inicial, opta por dar la razón a Unamuno. Más recientemente, en 1970, Trueman Dicken también se ha decidido por una solución filogenética semejante, sólo que ya no es Ávila la pretendida fuente de inspiración teresiana, sino el castillo de la Mota de Medina del Campo, que el crítico se esfuerza por comparar minuciosamente (y, nos parece, sin mucho éxito) con los siete castillos del misterioso símil de la reformadora ${ }^{91}$.

Ante estos intentos críticos, en el fondo poco afortunados, parecería que permanece incólume la pretendida originalidad literaria de Santa Teresa de Jesús. Pero esa pretendida originalidad ya la

nosso coraçom, e como lhe devem ser apropiadas certas fiis", Leal conselheiro, Lisboa, 1942).

${ }^{88}$ MAR INS, Alegorias, simbolos e exemplos morais da literatura medieval portuguesa (op. cit.). El erudito prodiga los ejemplos de tratadistas portugueses que alegorizan con el castillo en términos semejantes: Santo Antonio da Lisboa (Sermones et Evangelia Dominicarum, siglo XIII), Frei Roberto (su Chateau périlleux circuló ampliamente en portugués en el siglo XV), Frei Diego Rosario (siglo XVI).

89 Merece atención, sin embargo, el caso del Remedio de cuerpos humanos y silva de experiencias, del doctor Lobera (1542), que constituye un comprendio de anatomía humana bajo la alegoría de un torreón fortificado, y que guarda ciertos paralelos generales con el símbolo teresiano. Agradecemos a nuestro colega, Francisco Márquez Villanueva, el que nos facilitara copia de su estudio inédito al respecto ("El simbolismo del castillo interior: sentido y génesis", leido en la MLA, Chicago, 1974).

${ }_{90}$ El más socorrido es el pasaje del Evangelio de San Juan (XIV,2): "En la casa de mi Padre hay muchas moradas...", pero también se arguye el texto de San Pedro en su primera Epístola, V, 8.

91 "The imagery of the interior castle and ins implications", Ephemerides Carmelitacae, 21 (1970), pp. 198-218. 
empezó a menoscabar el gran arabista español Miguel Asín Palacios en un estudio que, sorprendentemente, casi ningún crítico reciente del tema ha tomado en cuenta: "El símil de los castillos y moradas del alma en la mística islámica y en Santa Teresa" AlAn, 2 (1946), pp. 263-274. Asín logra documentar entre los místicos musulmanes el esquema básico teresiano que Ahmad Algazel (hermano del célebre filósofo), en su opúsculo Kitāb al Taŷrid (Libro de la desnudez espiritual) parece esbozar en términos de círculos concéntricos. El maestro cree que el símil "adquiere ya un completo desarrollo y se nos ofrece precedente del teresiano en un pasaje, desgraciadamente anónimo, de los Nawadir, curiosa compilación de relatos y pensamientos religiosos....redactada a fines del siglo XVI" (pp. 267-268). El pasaje que traduce el arabista dice textualmente:

Puso Dios para todo hijo de Adán siete catillos, dentro de los cuales está Él y fuera de los cuales está Satanás ladrando como el perro. Cuando el hombre deja que se abra brecha en uno de ellos, entra por él Satanás. Conviene, por tanto, que los vigile y guarde con todo cuidado, particularmente el primer castillo, pues mientras permanezcan incólumes y en pie de cimientos no hay mal que temer. El primero de los castillos, que es de cándida perla, es la mortificación del alma sensitiva. Dentro de él hay un castillo de esmeralda, que es la pureza y sinceridad de intención. Dentro de él hay un castillo de brillante loza, que es el cumplimiento de los mandamientos de Dios positivos y negativos. Dentro de él hay un castillo de piedra, que es la gratitud a los beneficios divinos y la conformidad con el divino beneplácito. Dentro de él hay un castillo de hierro, que es el dejamiento en las manos de Dios. Dentro de él hay un castillo de plata que es la fe mística. Dentro de él hay un castillo de oro, que es la contemplación de Dios -iglorificado y honrado sea! Ya dijo Dios jensalzado sea! [Alcorán, XVI, 191] "Satanás no tiene poder sobre los que creen y ponen en Dios su confianza" (pp. 267-268).

En efecto, Asín logró dar con el germen esquemático pero preciso de Santa Teresa. Si bien no encontramos en los Nawādir la exhaustiva elaboración mística que la insigne escritora lleva a cabo, si están presentes aquí los elementos de una imagen que la santa creyó hija de su propia imaginación inspirada.

Pero el problema de los orígenes del símbolo del castillo no queda del todo resuelto por Asín Palacios, porque la evidencia documental que posee es la de un manuscrito de finales del siglo XVI - contemporáneo o posterior, por lo tanto, a la santa- y el arabista cree que el símbolo se perfecciona en el Islam hacia ese momento. Es decir, cronológicamente más o menos a la par con Santa Teresa. Hemos tenido, sin embargo, la fortuna de poder resolver algunas de las dudas del admirado maestro. El esquema simbólico de los siete castillos concéntricos del alma lo describe ya claramente Abu-1Hasan al Nūrí de Bagdad en sus Maqāmātal-qulüb(Moradas de los 
corazones) en pleno siglo IX. Y puede ser aun anterior. No parece arriesgado, ante esto, sospechar que estamos ante un motivo metafórico frecuente en el Islam. Los dos ejemplos que Asín y nosotros hemos podido documentar - con tantos siglos de diferencia en los manuscritos: siglo XVI, siglo IX - deben formar parte de una larga tradición literaria que se reitera durante siglos. El tratado del místico bagdadí es de particular interés porque ningún otro autor de los documentados hasta ahora (exceptuando al anónimo autor de los Nawädir) organiza los elementos del símbolo de manera tan cercana a Terèsa como Nürí. Veamos con qué precisión el maestro sufí preludia los Nawadir y esboza - nada menos que ocho siglos antes que la santa de Ávila - la imagen que la escritora consideró inspirada y privativa. Traducimos del árabe el tratado VII de dicho manuscrito (que edita Paul Nwyia ${ }^{92}$, titulado ("Los castillos del corazón creyente"):

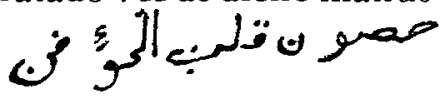

Has de saber que Dios - ensalzado sea! - creó en el corazón de los creyentes siete castillos con cerco y muros alrededor. Ordenó a los creyentes que estuvieran en el interior de estos castillos y colocó a Satanás afuera de ellos, y les ladra desde fuera como ladra el perro. El primer castillo cercado es de corindón y significa el conocimiento místico de Dios - iensalzado sea! - y a su alrededor un castillo de oro que es la fe en Dios - iensalzado sea! - y a su alrededor hay un castillo de plata que es la fidelidad en los dichos y la acción; y a su alrededor hay un castillo de hierro que es la conformidad con el beneplácito de Dios - iensalzado sea! - ; y a su alrededor hay un castillo de bronce que es la ejecución de las órdenes de Dios - iensalzado sea! - y a su alrededor hay un castillo de alumbre que es el cumplimiento de los mandamientos de Dios positivos y negativos; y alrededor de él hay un castillo de barro cocido que es la educación del alma sensitiva en toda acción.

Como dice la plabra de Dios - jalabada sea!-: "Contra mis servidores no tendrás poder" (Cor. XII, 40). El fiel está entonces en el interior de estos castillos, y aquel que está en el castillo de corindón, Satanás no tiene manera de llegar a él, siempre que el fiel cumpla con las reglas de la educación del alma sensitiva. Pero si deja de cumplirlos y dice "no es necesario", entonces Satanás obtiene de él este castillo, que es el de barro cocido, y codicia el próximo. Cuando el fiel se vuelve negligente en el cumplimiento de los mandamientos de Dios positivos y negativos, obtiene Satanás de él el castillo de alumbre, y codicia el tercero. Cuando el fiel abandona la conformidad con el divino beneplácito de Dios - iensalzado sea! - toma Satanás el castillo de cobre y codicia el cuarto, y así sucesivamente hasta el último castillo (corresponde a la p. 135 de la edición del ms. de Nwyia).

Salta a la vista que el esquema simbólico es de la misma familia de los Nawädir del siglo XVI y que también contiene - si bien muy

${ }^{92}$ Textes mystiques inédits d'Abū-Hasam al Nüri, Imprimerie Catholique, Beyrouth, 1968. 
constreñidos - todos los elementos principales del símil teresiano: el alma -o mejor camino místico- se concibe en siete moradas sucesivas representadas por castillos concéntricos. Satanás acecha sobre todo las primeras moradas y el fiel que logra alcanzar la última alcanza la unión con Dios. Hay coincidencias específicas de mucho interés: Santa Teresa nos habla de las "moradas" del alma, sin duda recordando el versículo de San Juna (14:2) "En la casa de mi Padre hay muchas moradas". Sin embargo, como ha demostrado Miguel Asín en sus Sädilies y alumbrados, el concepto de morada como estado permanente del alma (opuesto a otros más pasajeros) parece derivativo del concepto islámico de maqam o morada, que significa precisamente eso. El tecnicismo es inusitado en la espiritualidad cristiana medieval, pero lo acuñaron sufíes como Nūri y al-Huŷwiri cientos de años antes de que adquiriera carta de naturaleza en la escuela carmelitana.

Nūrí compara al demonio enemigo del alma con un perro: Santa Teresa con alimañas. La santa parecería más cerca de los šādilíes del siglo XIII que hablaban concretamente de la turba de alimañas y bestias que asaltan el castillo interior. Pero el místico bagdadí tampoco está demasiado lejos de la reformadora: ya hemos aludido al impacto que tiene para un musulmán, acostumbrado a ritos purificadores como la ablución, la noción de la impureza. Y perro es precisamente el animal impuro por excelencia en el Islam. De ahí que el "perro" de Nuri se traduzca emocionalmente por las "alimañas" o "bestezuelas inmundas" con las que Santa Teresa elige metaforizar nuestras impurezas o el demonio mismo.

Una diferencia obvia entre los castillos teresianos y los árabes son los materiales preciosos que los constituyen. Es interesante observar que Santa Teresa parecería haber tornado diamantinos y transparentes los castillos multicolores del símbolo islámico. En esto sin duda difieren, pero advirtamos que Nūri de Bagdad se sirve de la materia prima de sus castillos para indicarnos el progreso espiritual del alma dentro de sí misma, Y su itinerario místico no difiere mucho del de Santa Teresa. Considerados de afuera hacia adentro, los materiales de que están hechos los castillos van subiendo en calidad, al igual que el camino sublime que representan: el castillo de barro (materia deleznable) simboliza la mortificación del alma sensitiva (es decir los principios de la vida espiritual). Desde ahí vamos ascendiendo - alumbre, bronce, hierro, plata, orohasta llegar al castillo interior de la unión con Dios, que es de corindón o iāqüt y que parecería constituir, en hermosa culminación artística y simbólica, la piedra preciosa que engastan los metales anteriores.

Aunque las esquemáticas etapas espirituales del Maqāmāt-alqulüb no corresponden con perfección a las complejísimas que articula la reformadora en su largo tratado, cabe advertir que en 
ambos casos hay un grado ascendente de perfección espiritual muy claro. Los castillos primero y séptimo de Teresa y los musulmanes sí coinciden con exactitud: en el primero se mortifica aún el alma sensitiva, en el ultimo se posee ya a Dios ${ }^{93}$.

Pero con esto no queremos implicar - ni mucho menos-que la fuente inmediata de la santa de Ávila fuese Abū-l-Hsan-al-Nūrī. Lo que sí proponemos es que la materia prima del símbolo de los castillos es islámica. Los musulmanes elaboran el símil a lo largo de toda la Edad Media - Nürí y el autor de los Nawädir no son sino dos ejemplos aislados (aunque muy significativos) del símbolo islámico de los castillos místicos. Se trata de un verdadero lugar común en la literatura sufí: Algazel en su $I h y \vec{a}$ ' alude repetidamente al castillo espiritual cuyas puertas hay que defender del asalto del diablo ${ }^{94}$, e Ibn-'Arabí en su Futūhāt (II, 768-774) representa sus iluminaciones esotéricas con un alcázar de multitud de cámaras que se van franqueando sucesivamente a medida que avanza en conocimiento místico. El persa Nezámí (siglo XII) en su Haft Paykar (Siete princesas) nos habla del alma en la forma de siete castillos [o de un castillo con siete cúpulas que son a su vez castillos] que corresponden al color y a las características de los siete planetas y que habitan siete princesas vestidas a su vez de estos colores alusivos. En el séptimo castillo, que es blanco o transparente, se produce metafóricamente la unión con Dios. El motivo alegórico fue reproducido insistentemente por los miniaturistas persas. Tan cara es al Islam la metaforizaciónm del alma en castillo que trasciende al lenguaje popular: en árabe se dice muhāsana, que significa algo así como "que te proteja el castillo de Dios alrededor tuyo".

Santa Teresa no habrá inaugurado pues el símil de los castillos concéntricos en la historia de la historia mística. Es tal el peso de la evidencia documental que acerca a la santa a la elaboración literaria islámica de los castillos que nos obliga a plantearnos la pregunta de si estamos ante un caso de filiación cultural musulmana de la reformadora. Será quizá el caso más dramático pero - ya lo hemos visto- no el único de su literatura mística.

\section{RECAPITULACIONES}

No nos detendremos en los motivos doctrinales que San Juan y Santa Teresa -entre otros espirituales del Siglo de Oro, incluyendo

${ }_{93}$ La idea de la concentricidad de estos siete castillos sucesivos es clarísima en Santa Teresa. En el siguiente pasaje de sus Moradas describe sus moradas de adentro hacia afuera, exactamente igual que Nürî: "No havéis de entender estas moradas una en pos de otra como cosa en hilada, sino poned los ojos en el centro, que es la pieza u palacio a donde está el rey, y considerad como un palmito, que para llegar a lo que es de comer tiene muchas coberturas..." (Moradas, 1, 2, 8, OC, p. 369)

94 "Le coeur est une fortresse dont Satan veut s'emparer; il est d'obligation personelle d'en garder les voies d'accès contre les tentations diaboliques; on me peut dominer le diable qu'en 
los alumbrados - comparten de cerca con los sufíes, porque ya han sido destacados por Asín Palacios o sus discípulos y sobre todo porque muchos implicarían un análisis doctrinal que caería fuera de nuestro estudio concreto de una simbología o terminología literaria compartida. Recordemos de paso sólo alguns casos muy elocunetes, para dramatizar el hecho de que la mística musulmana y la cristiana tiene más puntos en común de los que aquí hemos ido esbozando. El amor puro, que desprecia cielo o infierno y que San Juan y numerosos espirituales españoles del Siglo de Oro comparten con el anónimo autor del Soneto "No me mueve, mi Dios, para quererte" parecería tener una filiación espiritual islámica, según hemos estudiado en otro lugar ${ }^{95}$. Asimismo, como ha visto Asín, parecen familiares al Islam, donde son previas, otras posturas espirituales como el rechazo a los carismas o milagros; el énfasis en el aprecio a los beneficios divinos (la escuela de los Beneficios Divinos que tanto estudia Bataillon en su Erasmo y España la preludió Algazel); la virtud de la muräqaba (cf. Pareja, p. 313) que es el actuar como si dios, siempre presente, vigilase de cerca la actuación del devoto, (cf. Pareja, p. 315; Nicholson, Misticos ..., p. 76; Schimmel Mystical ..., p. 29); el uso de la meditación sin imágenes (tantos siglos antes que Erasmo); la oración de quietud - recordemos a Santa Teresa- que deja al alma mutma'inna o "pacificada" (cf. Nwyia, Ibn 'Ata' ..., 255; Corbin, L'homme ..., p. 104; Nasr, Three Muslim ..., p. 35); la impecabilidad o šath ("trueque, cambio") a través de la que tantos alumbrados ${ }^{96}$ se creyeron impecables porque Dios los poseía y actuaba a través de ellos (Nasr, ibid., p. 115).

Hasta la famosa letrilla adjudicada a Santa Teresa, "Nada te turbe...", parecería preludiada por los šädilies: "El que a Dios tiene, nada le falta", dice Ibn- Abbád, con fórmula no dispar de la de Santa Teresa. Sin Dios, nada tampoco le sirve. "Lograda una morada o conseguido un favor ni desea, ni pide conservarlo, como tampoco se aflige de perderlo, porque solo Dios le basta" (Ibn al'Aríf, apud Asín, Obras escogidas, t. 1, Madrid, 1945, p. 269). Consignemos, por último, y aunque, como advierte Asín (El Islam..., p. 158), ya lo esbozan San Nilo y San Juan Clímaco, la enorme insistencia de los musulmanes en un motivo que San Ignacio hará célebre: el perinde ac cadaver, utilizado por Tustarí (cf. Massignon, Lexique ..., p. 42), por al-Naqšabandi (cf. Arberry, Sufism, p. 131), por Ibn- Arabí, por Algazel. Para este último era el más alto grado del dejamiento o tawakkul (cf. Ihy $\vec{a}$ '..., p. 385), que Pareja describe en los siguientes términos:

\footnotetext{
connaissant les portes d'accès. En voici seulement les plus importantes... [la colère, l'envie et l'avarice, la gloutonnerie, l'amour de la parure, etc:] (Ihyä, op. cit., pp. 215-216).

95 "Anonimia y posible filiación espiritual islámica...", cit. supra, nota 1 .

${ }^{96}$ Sobre modalidades espirituales islámicas entre los alumbrados, cf. nuestro citado ensayo "Anonimia...", pp. 256-261.
} 
El grado tercero [del tawakkul] consiste en que el alma se confíe a Allah en sus actos de movimiento o reposo como el cadáver en manos del que lo lava para amortajarlo, con la sola diferencia de que el sujeto vivo se ve a sí mismo como muerto y movido por la omnipotencia de Allah (p. 308) ${ }^{97}$.

Recapitulemos lo propuesto en este estudio. San Juan y Santa Teresa no habrán inaugurado en la literatura europea símbolos místicos como el de la noche oscura, el de las lámparas de fuego y los castillos del alma, pero su elaboración cristiana resulta genial y es la que hace famosa estas imágenes en la espiritualidad occidental. San Juan de la Cruz y Santa Teresa de Jesús las llevan a tales alturas literarias y espirituales que se hace a menudo pálido su lejano origen en tierras de Oriente. En este mismo sentido, decíamos al principio de nuestro ensayo, vio Asín la escatologia de la Divina Comedia, cuyo origen musulmán demuestra convincentemente: el poeta florentino logra una "sublime adaptación de modelos abocetados y a menudo infantiles a un ideal artístico más alto" (Escatología ..., p. 529). Otro tanto San Juan y Santa Teresa, que no se limitan a ser derivativos con pasividad, sino que parecerían reaccionar creativamente ante estas posibles influencias musulmamas, que adaptan, transforman y funden con su propia herencia cristiana occidental, enriqueciéndola de manera extraordinaria. ${ }^{98}$

Pero las influencias sufíes presentes en la obra de los reformadores son tan abundantes y tan significativas - es lo que hemos querido ir demostrando a lo largo de este estudio- que marcan y

97 ¿Tuvo San Juan, de alguna manera, acceso indirecto a una imagen poética muy socorrida de la poesía árabe laica? Se trata de la metáfora del jardín florido como cielo estrellado, que los críticos consideran como motivo característico de la poesía árabe, y que ha dado pie a todo un género poético denomina nauriyya (cl. Henri Péréz, La poésie andalouse en arabe clasique au $x z^{\natural}$ siècle, Paris, 1953 y FREDERICK BARGEBUHR, op. cit.) Veamos, entre tantos ejemplos que cabría citar, el de Abū Firás, príncipe de la dinastía Hamdānid, que muere hacia 968: "The sky wept upon the dizzling of its tears / whereupon she [the meadow] began to smile showing stars of the sky [i.e., flowers, like a mouth showing teeth]" (BARGEBUHR, op. cit., p. 336). La imagen es tan extendida que la heredan los poetas hispano-hebreos como Mosé ibn Fzra: ". . . los árboles con las estrellas de sus / flores al sol sirven de firmamento". (DÍEZ MACHO, op. cit., p. 45). Y oigamos a San Juan, que da un vuelco algo inesperado a su glosa al verso "¡oh prado de verduras!" al entenderlo desde el punto de vista del género poético de la nauriyya: "Esta es la consideración del cielo, al cual llama prado de verduras, porque las cosas que hay en él ciradas siempre están con verdura inmarcesible, que ni fenecen ni se marchitan con el tiempo, y en ellas como [en] frescas verduras se recrean y deleitan los justos. En la cual consideración también se comprende toda la diferencia de las hermosas estrellas y otros planetas celestiales" (VO, p. 642).

98 Deseamos hacer constar, una vez más, que en otros estudios (en nuestro libro San Juan y el Islam y en el estudio en colaboración con M. T. Narváez citado en nota 1) nos hemos ocupado del espinoso problema de cómo los místicos del Carmelo se harían eco de estas filiaciones islámicas en pleno siglo XVI. No fueron ellos los únicos en recibirlas: las obras de muchos espirituales europeos medievales parecen influidas por motivos islámicos; no las hemos tomado en cuenta aquí por razones de espacio. 
matizan para siempre la literatura de San Juan y de Santa Teresa. Si no conocemos estos referentes islámicos, la obra de ambos (y aun la de muchos de sus compatriotas) deviene innecesariamente misteriosa y a menudo falsamente original. No podemos, con honradez intelectual, no tomar en cuenta el hecho de que San Juan y Santa Teresa manejan en buena medida un lenguaje técnico y una simbologia que los musulmanes habían cifrado en una compleja literatura espiritual siglos antes que los reformadores carmelitas vieran la luz. San Juan y Santa Teresa no son menos cristianos por ello. Sí, más fecundos. Ante ciertos rasgos de su literatura, debemos comenzar a hablar no de un "Islam cristianizado" como propuso en otra ocasión el maestro Asín, sino de un "cristianismo islamizado", Gracias a ello, la literatura religiosa de estos místicos del Siglo de Oro español, entreverada de motivos musulmanes, resulta una de las más misteriosas, complejas y brillantes de Europa, y una de las más fecundamente mestizas.

Universidad de Puerto Rico.

Harvard University. 